\title{
Case Study of the ARRA-Funded GSHP Demonstration at the Natural Sources Building, Montana Tech
}

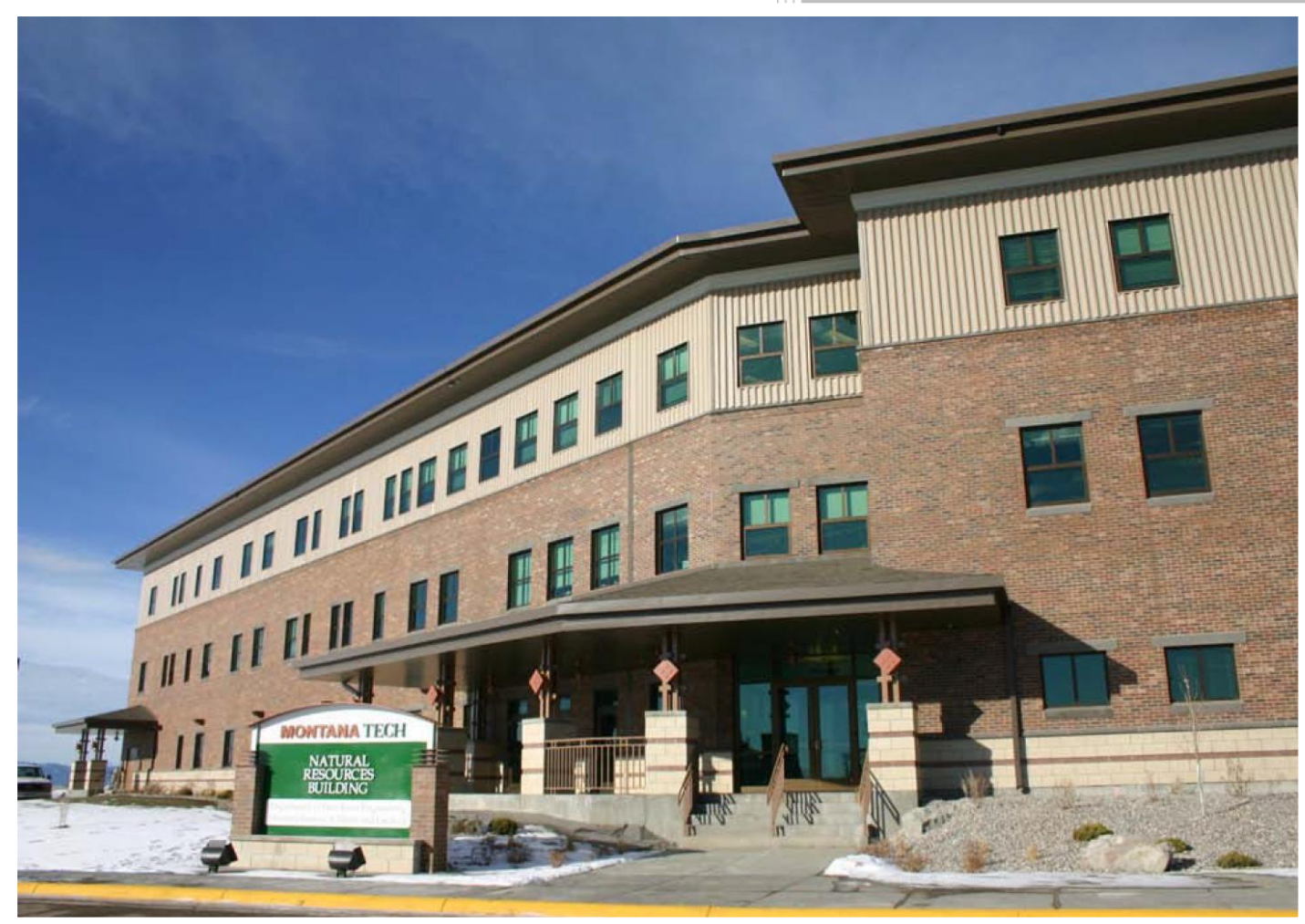

Mini Malhotra, PhD Xiaobing Liu, PhD Adam Walburger

December 2014 


\title{
DOCUMENT AVAILABILITY
}

Reports produced after January 1, 1996, are generally available free via the U.S. Department of Energy (DOE) Information Bridge.

Web site http://www.osti.gov/bridge

Reports produced before January 1, 1996, may be purchased by members of the public from the following source.

\author{
National Technical Information Service \\ 5285 Port Royal Road \\ Springfield, VA 22161 \\ Telephone 703-605-6000 (1-800-553-6847) \\ TDD 703-487-4639 \\ Fax 703-605-6900 \\ E-mail info@ntis.gov \\ Web site http://www.ntis.gov/support/ordernowabout.htm
}

Reports are available to DOE employees, DOE contractors, Energy Technology Data Exchange (ETDE) representatives, and International Nuclear Information System (INIS) representatives from the following source.

Office of Scientific and Technical Information

P.O. Box 62

Oak Ridge, TN 37831

Telephone 865-576-8401

Fax 865-576-5728

E-mail reports@osti.gov

Web site http://www.osti.gov/contact.html

This report was prepared as an account of work sponsored by an agency of the United States Government. Neither the United States Government nor any agency thereof, nor any of their employees, makes any warranty, express or implied, or assumes any legal liability or responsibility for the accuracy, completeness, or usefulness of any information, apparatus, product, or process disclosed, or represents that its use would not infringe privately owned rights. Reference herein to any specific commercial product, process, or service by trade name, trademark, manufacturer, or otherwise, does not necessarily constitute or imply its endorsement, recommendation, or favoring by the United States Government or any agency thereof. The views and opinions of authors expressed herein do not necessarily state or reflect those of the United States Government or any agency thereof. 
Energy and Transportation Science Division

\title{
CASE STUDY OF THE ARRA-FUNDED GSHP DEMONSTRATION AT THE NATURAL SOURCES BUILDING, MONTANA TECH
}

\author{
Mini Malhotra, $\mathrm{PhD}$ \\ Xiaobing Liu, $\mathrm{PhD}$ \\ Adam Walburger* \\ *CDH Energy Corp.
}

Date Published: December 2014

\author{
Prepared by \\ OAK RIDGE NATIONAL LABORATORY \\ Oak Ridge, Tennessee 37831-6283 \\ managed by \\ UT-BATTELLE, LLC \\ for the \\ U.S. DEPARTMENT OF ENERGY \\ under contract DE-AC05-00OR22725
}




\section{ACKNOWLEDGMENTS}

This work was sponsored by the U.S. Department of Energy, Building Technology Office. Special thanks to Donald M. Blackketter and his colleagues at Montana Tech of the University of Montana for providing data and other inputs needed for this case study. 



\section{EXECUTIVE SUMMARY}

Under the American Recovery and Reinvestment Act (ARRA), 26 ground source heat pump (GSHP) projects were competitively selected in 2009 to demonstrate the benefits of GSHP systems and innovative technologies for cost reduction and/or performance improvement. One of the selected demonstration projects was proposed by Montana Tech of the University of Montana for a 56,000 sq ft, newly constructed, on-campus research facility - the Natural Resources Building (NRB) located in Butte, Montana.

This demonstrated GSHP system consists of a 50 ton water-to-water heat pump and a closed-loop ground heat exchanger with two redundant $7.5 \mathrm{hp}$ constant-speed pumps to use water in the nearby flooded mines as a heat source or heat sink. It works in conjunction with the originally installed steam HX and an aircooled chiller to provide space heating and cooling. It is coupled with the existing hot water and chilled water piping in the building and operates in the heating or cooling mode based on the outdoor air temperature. The ground loop pumps operate in conjunction with the existing pumps in the building hot and chilled water loops for the operation of the heat pump unit.

The goal of this demonstration project is to validate the technical and economic feasibility of the demonstrated commercial-scale GSHP system in the region, and illustrate the feasibility of using mine waters as the heat sink and source for GSHP systems. Should the demonstration prove satisfactory and feasible, it will encourage similar GSHP applications using mine water, thus help save energy and reduce carbon emissions.

The actual performance of the system is analyzed with available measured data for January through July 2014. The annual energy performance is predicted and compared with a baseline scenario, with the heating and cooling provided by the originally designed systems. The comparison is made in terms of energy savings, operating cost savings, cost-effectiveness, and environmental benefits. Finally, limitations in conducting the analysis are identified and recommendations for improvement in the control and operation of such systems are made.

\section{Energy Performance and Cost Effectiveness}

The GSHP system was operated intermittently from January through March, and shut off in May and June. The GSHP system operated in the heating mode during January through April with a heating COP of 4.0 for the heat pump and 3.5 for the GSHP system. In July, the operation alternated between heating and cooling modes, with the cooling EER of 15.3 for the heat pump and 12.8 for the GSHP system. The ground loop pumping power fraction ranged between $8 \%$ and $60 \%$, higher at lower building loads, and averaged $12-13 \%$ when aggregated by month. The daily pump energy use was linearly related to the heating and cooling provided by the heat pump.

The available measured data does not include building cooling loop measurement. Therefore, building cooling loads could not be predicted. Also, the measured mine water temperature was found higher than the outdoor air temperature in the winter and summer, which suggested that using the GSHP system to provide cooling would be less efficient than using the existing air-cooled chiller. Therefore, the annual energy analysis was performed based on the premise that the GSHP system would provide only heating.

The analysis of measured data identified the potential for improvement in the control of the heat pump. With the recommended OA reset control, the full-year performance analysis showed that the annual average COPs of the heat pump and GSHP system were 4.2 and 3.7, respectively, both of which were 5$6 \%$ higher than those measured during the 4 month period. The predicted ground loop pumping power annually accounts for $12 \%$ of the total GSHP system energy use.

Compared with the baseline system (i.e., the existing steam system using a natural gas boiler), the GSHP system achieved significant energy savings and $\mathrm{CO}_{2}$ emission reduction. The GSHP system demonstrated 
$77.7 \%$ site energy savings, $43 \%$ source energy savings, and $44 \% \mathrm{CO}_{2}$ emission reduction compared with the natural gas-fired boiler. Based on a $\$ 9.63 / \mathrm{MMBtu}$ natural gas cost and a $\$ 0.08 / \mathrm{kWh}$ electricity cost, obtained from the site, the operating cost savings were $\$ 17,227$ per year.

The installed cost $(\$ 750,000$ for the mine loop heat exchanger, i.e., $\$ 15,000 /$ ton) of the demonstrated GSHP system is higher than that of conventional GSHP systems (about \$7,000/ton on average in 2006 dollars, or $\$ 8,200 /$ ton in 2014 dollars) that use vertical bore ground heat exchangers. As an experimental work to research the potential of using mine water as a potential heat source/sink, the project cost may have included several other research-related costs, which will not exist for non-research projects. Unfortunately, the cost breakdown was not available to the authors when this study was conducted. Assuming $\$ 50,000$ cost of the 50-ton WWHP unit, the payback period is 46 years. Table E-1 provides a summary of comparison between the two systems.

Table E-1. Summary of comparisons between the GSHP system and the baseline system

\begin{tabular}{|l|c|c|c|}
\hline & $\begin{array}{c}\text { Steam HX served by a } \\
\text { natural gas boiler }\end{array}$ & GSHP system & Savings \\
\hline Site energy use (MMBtu) & 4,213 & 1,302 & $69.1 \%$ \\
\hline Source energy use (MMBtu) & 4,601 & 2,832 & $38.4 \%$ \\
\hline $\mathrm{CO}_{2}$ emissions (lb) & 621,046 & 376,969 & $39.3 \%$ \\
\hline Total annual energy cost (\$) & $\$ 40,574$ & $\$ 23,347$ & $42.5 \%$ \\
\hline Operating cost savings (\$) & - & - & $\$ 17,227$ \\
\hline Cost premium $(\$)$ & - & - & $\$ 800,000$ \\
\hline Payback period (years) & - & - & 46 \\
\hline
\end{tabular}

${ }^{\mathrm{a}}$ Based on the utility rates for the site, which are $\$ 9.63 / \mathrm{MMBtu}$ and $\$ 0.08 / \mathrm{kWh}$.

\section{Lessons Learned and Recommendations for Further Improvements}

- To achieve its maximum potential, the GSHP system must be able to operate as much as possible within the manufacturer-specified range of operating conditions. Also, its operating efficiency can be maximized by optimizing the load-side supply water temperatures. The following measures can be utilized to achieve these objectives:

- By optimizing the OA reset schedule for the building hot water loop to allow lower supply and return water temperature, the operation of GSHP system can be maximized even at peak heating load conditions, while meeting the manufacture-specified operating conditions.

- A holistic system design approach is needed to select and size the heat delivery equipment/ terminal units that do not require very high supply hot water temperature to deliver sufficient heat to the building. A lower supply temperature would result in higher operating efficiency and maximum operation of the heat pump.

- Building chilled water loop measurements for estimating the building cooling loads and a longterm measurements of the mine water temperature (which stays warmer than the outdoor air) are needed to evaluate the tradeoff between using the mine water (a) solely as a heat source, which may result in temperature rise over the years, thereby, reducing the heating efficiency of the GSHP system, and (b) both as a heat source and a heat sink, which would result in relatively stable mine water temperature and stable GSHP heating and cooling efficiency over the years, but provide cooling at a lower efficiency compared to the existing air-cooled chiller.

- Control of heat pump operation should be improved to avoid a large amount of summertime reheat by the steam heating system, caused by the heat pump operating in the cooling mode.

- Pumping control could be refined to avoid wasting pumping energy when the heat pump is not in operation. 



\section{CONTENTS}

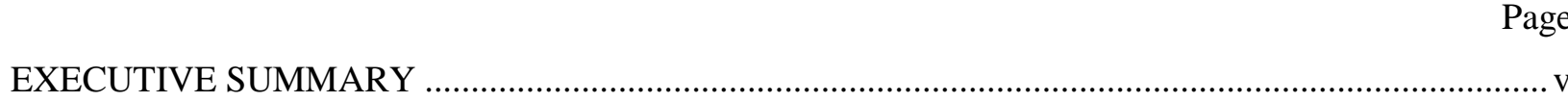

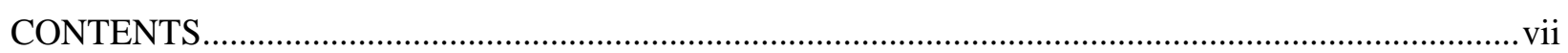

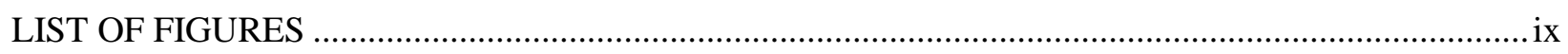

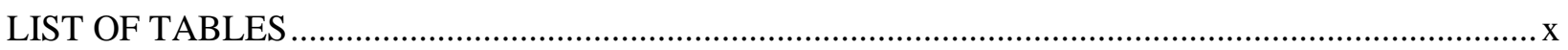

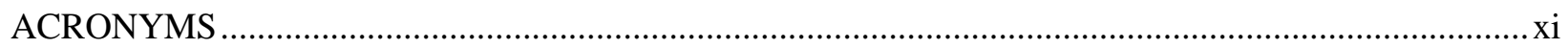

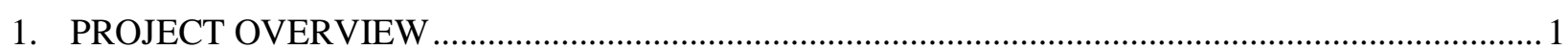

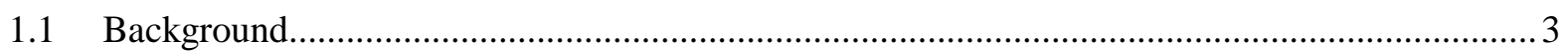

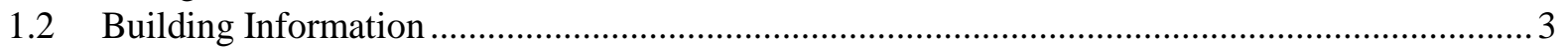

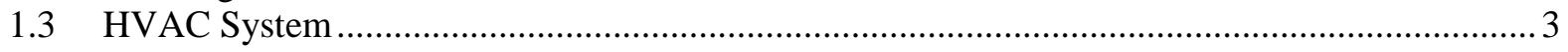

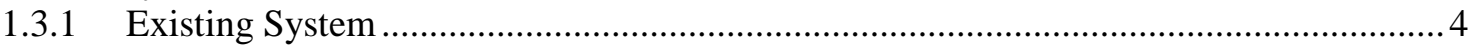

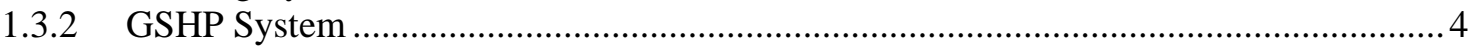

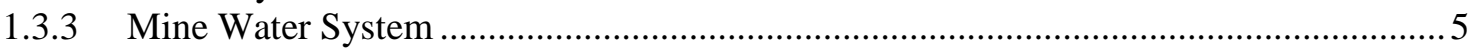

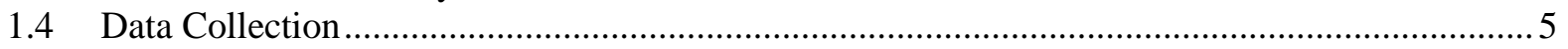

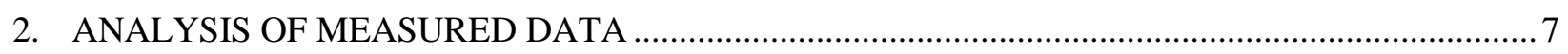

2.1 Measured Water Temperature Trend and Flow Rate ...................................................... 7

2.1.1 Ground Loop (Heat Pump Source-Side Loop) …..................................................... 7

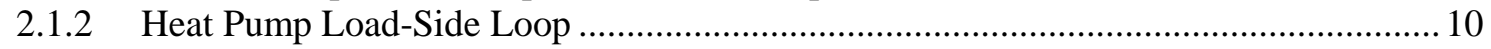

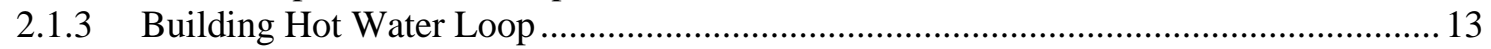

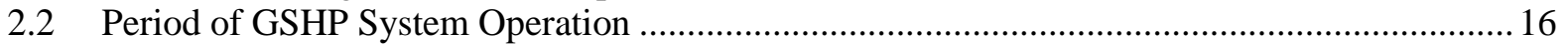

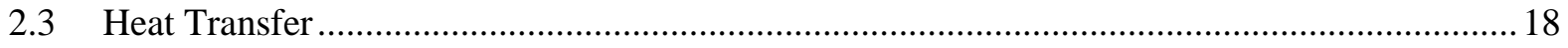

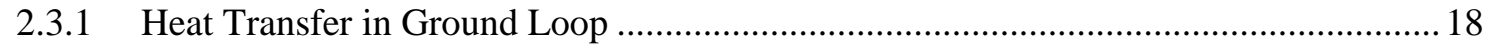

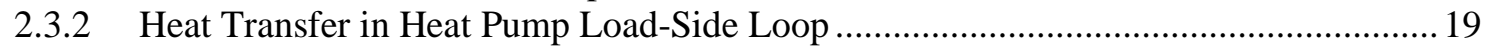

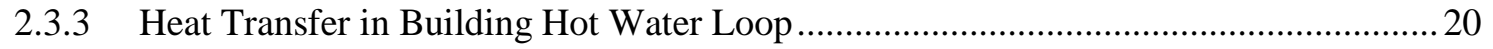

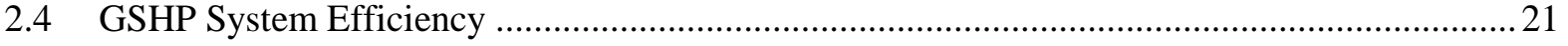

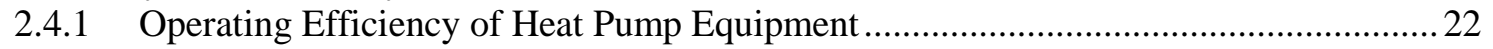

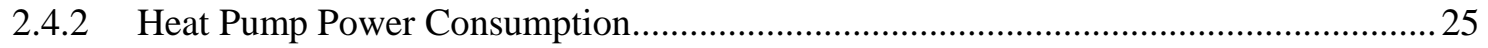

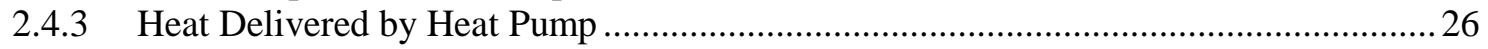

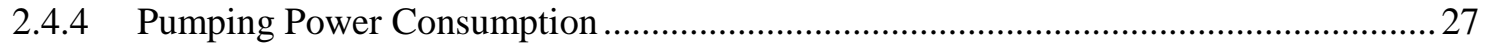

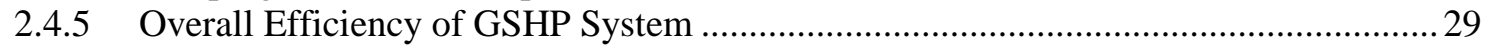

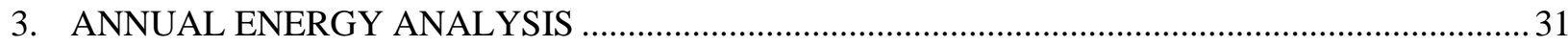

3.1 Prediction of Full-Year Performance of GSHP System ….................................................... 31

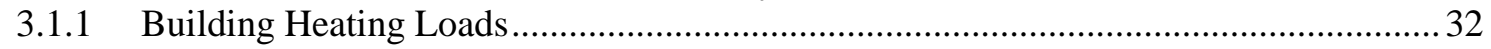

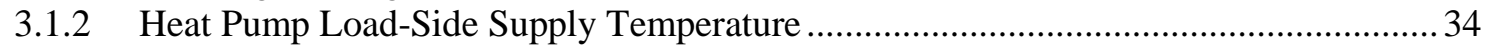

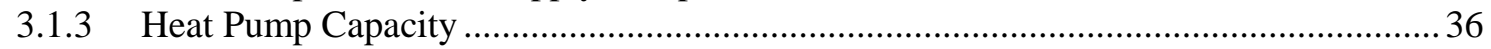

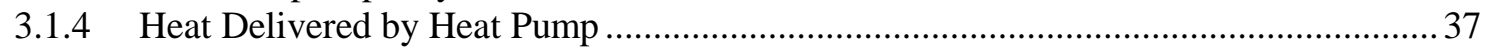

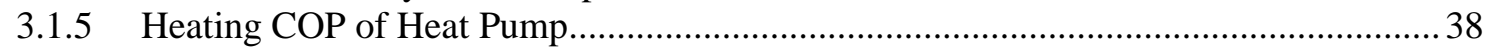

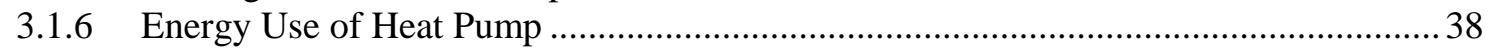

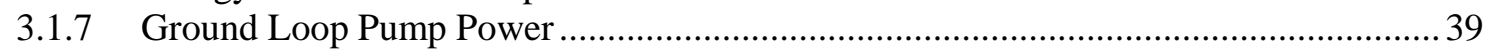

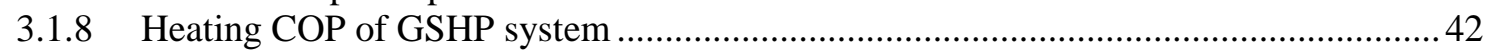

3.1.9 Summary of Full-Year Performance of GSHP System .......................................... 43

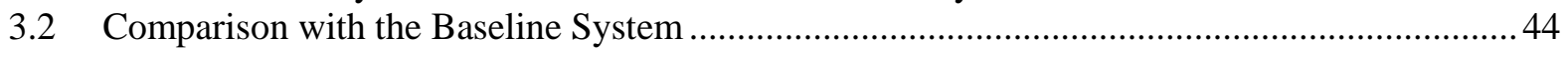

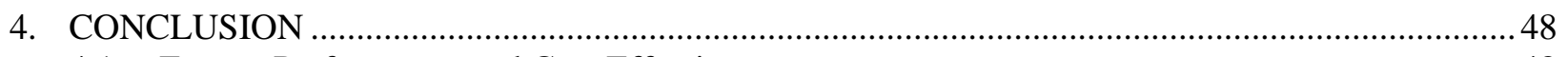

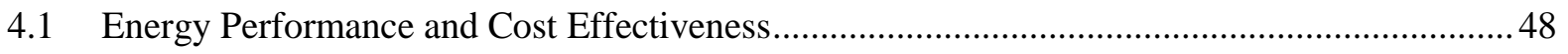




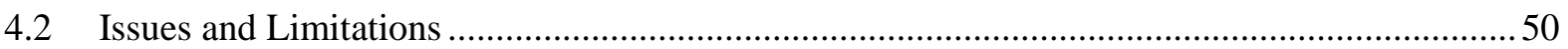

4.3 Lessons Learned and Recommendations for Further Improvements ....................................50

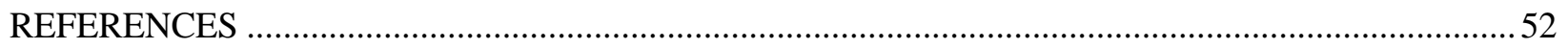




\section{LIST OF FIGURES}

Figure $\quad$ Page

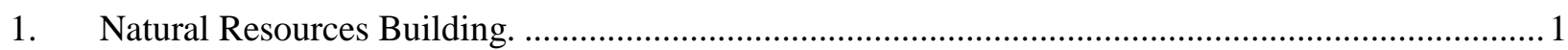

2. Geographic location within the United States of the GSHP demonstration site ............................. 1

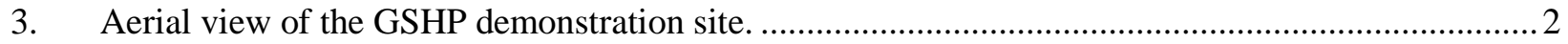

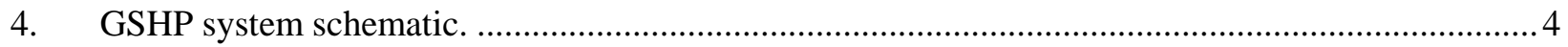

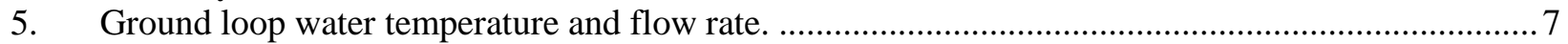

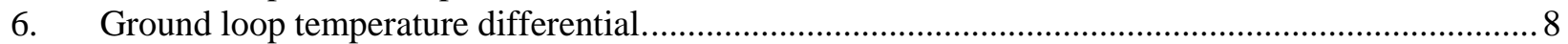

7. Ground loop water temperature differential versus flow rate .................................................... 9

8. Ground loop water temperature versus outdoor air temperature (excluding invalid data)................ 9

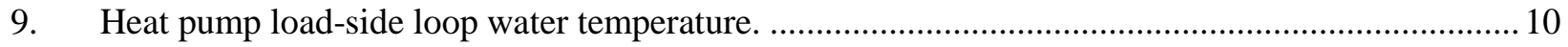

10. Heat pump load-side loop temperature differential.................................................................... 11

11. Heat pump load-side loop temperature differential versus return water temperature...................... 12

12. Heat pump load-side loop water temperature versus outdoor air temperature................................ 12

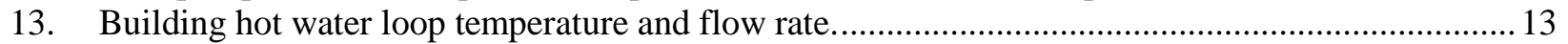

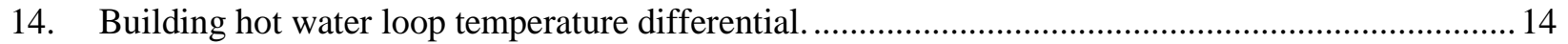

15. Building hot water loop temperature differential and flow rate versus outdoor air

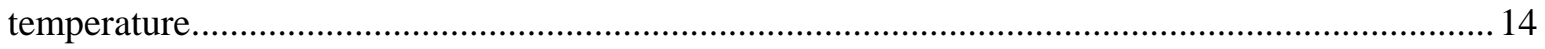

16. Building hot water loop temperature versus outdoor air temperature .......................................... 15

17. Building hot water loop and heat pump building loop water temperature versus outdoor air

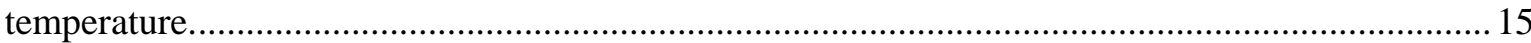

18. Building hot water loop temperature during heat pump operation in the cooling mode

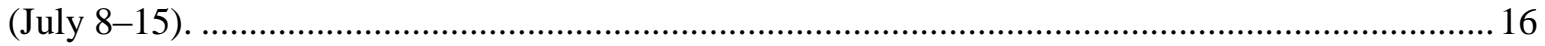

19. Ground loop flow rate versus building hot water loop return temperature................................... 17

20. Temperature differential in (left) ground loop and (right) heat pump building loop versus

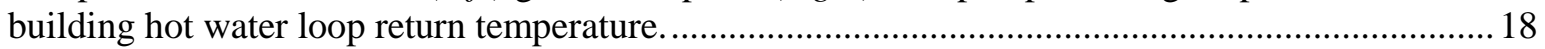

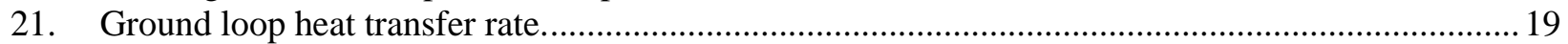

22. Heat pump delivered energy (flow rate $*$ deltaT, assuming constant flow rate)...........................20

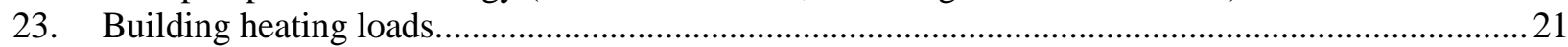

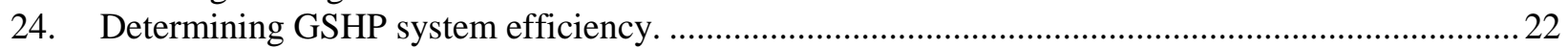

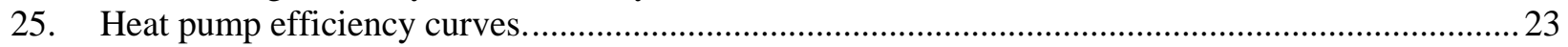

26. Measured heat pump leaving source-side and leaving load-side water temperature. ......................24

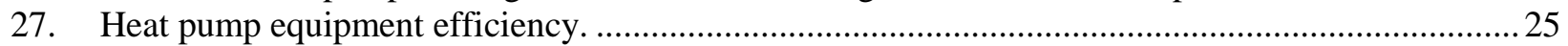

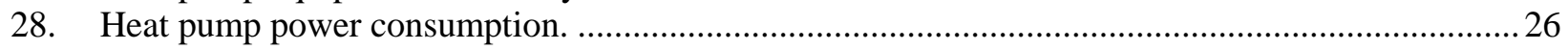

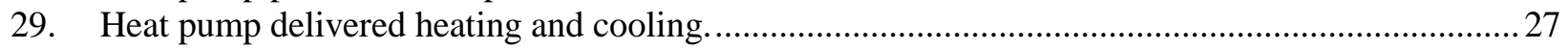

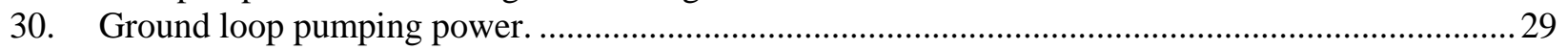

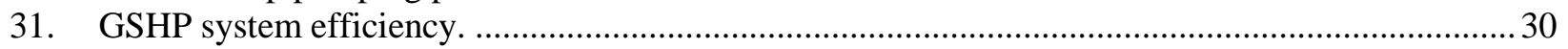

32. Outdoor air temperature versus ground loop supply water temperature ........................................ 31

33. Schematic of GSHP system performance prediction. ................................................................. 32

34. Curve-fit for building heating loads as a function of outdoor air temperature.................................. 33

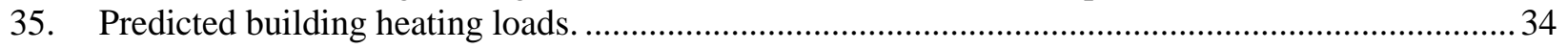

36. Building heating loop and heat pump loop water temperature. …................................................. 35

37. Recommended schedule for heat pump loop water temperature.................................................. 36

38. Heat pump heating capacity as function of heat pump load-side supply water temperature. ............36

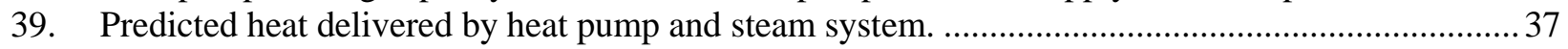

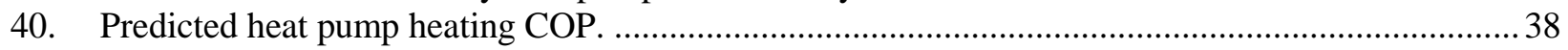

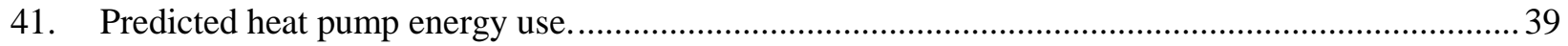

42. Curve-fit of ground loop pumping energy use as a function of heat pump heat output...................40

43. Predicted monthly ground loop pump energy use......................................................................... 41 
44. Predicted ground loop pump energy use fraction.

45. Predicted heating COP of heat pump equipment and GSHP system. ......................................42

46. Comparison of measured and predicted performance of GSHP system. ......................................43

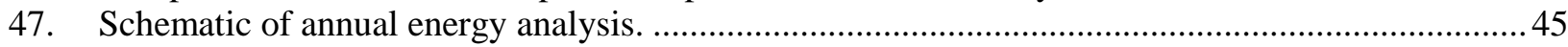

48. System efficiency of the baseline system and GSHP system....................................................... 46

49. Comparison of site and source energy use and $\mathrm{CO}_{2}$ emissions between the GSHP system and the baseline system.

\section{LIST OF TABLES}

Table $\quad$ Page

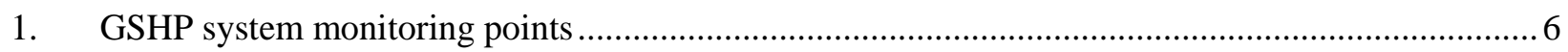

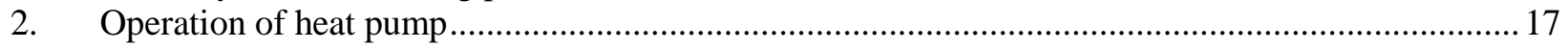

3. Coefficients for the heat pump performance curve-fit .................................................................2

4. Summary of predicted full-year performance data.......................................................................... 44

5. Summary of comparisons between the GSHP system and the baseline system..............................50 


\section{ACRONYMS}

ARRA

$\mathrm{CO}_{2} \mathrm{e}$

COP

DOE

EER

FEC

GSHP

HDPE

HRV

HX

NRB

NREL

OA

ORNL

QBH

QGL-

QGL+

QHPC

QHPH

TBHR

TBHS

TD

THPR

THPS

TMWR

TMWS

TOA

VAV

W

WHPC

WHPH

WLP
American Recovery \& Reinvestment Act of 2009

equivalent $\mathrm{CO}_{2}$ emissions

coefficient of performance

Department of Energy

energy efficiency rating

Flathead Electric Cooperative, Inc.

ground source heat pump

high-density polyethylene

heat recovery ventilator

heat exchanger

Natural Resources Building

National Renewable Energy Laboratory

outdoor air

Oak Ridge National Laboratory

building heating loads

heat rejected to ground loop

heat extracted from ground loop

heat pump cooling delivered

heat pump heating delivered

building hot water return temperature

building hot water supply temperature

temperature differential

heat pump return temperature

heat pump supply temperature

mine water return temperature (or heat pump leaving source-side temperature)

mine water supply temperature

outdoor air temperature

variable air volume

GSHP system power consumption

heat pump power consumption in the cooling mode

heat pump power consumption in the heating mode

ground loop pump power consumption 



\section{PROJECT OVERVIEW}

The Natural Resources Building (NRB) at Montana Tech (Fig. 1) is a newly constructed 56,000 sq ft research facility in Butte, Montana. Figure 2 shows the geographical location within the United States of the demonstration site, which is in a cold climate zone with long and cold winters and short but mild and somewhat wet summers. After completion in December 2009, as originally designed with a steam system and an air-cooled chiller, NRB was competitively selected by the US Department of Energy (DOE) to demonstrate a unique, innovative ground source heat pump (GSHP) system that uses the warm water of a flooded mine in the vicinity (Fig. 3) as the heat source and heat sink to provide heating and cooling supplemented by the existing systems. Construction on the GSHP system began in 2011. Performance data since January 2014 for the GSHP system are available.

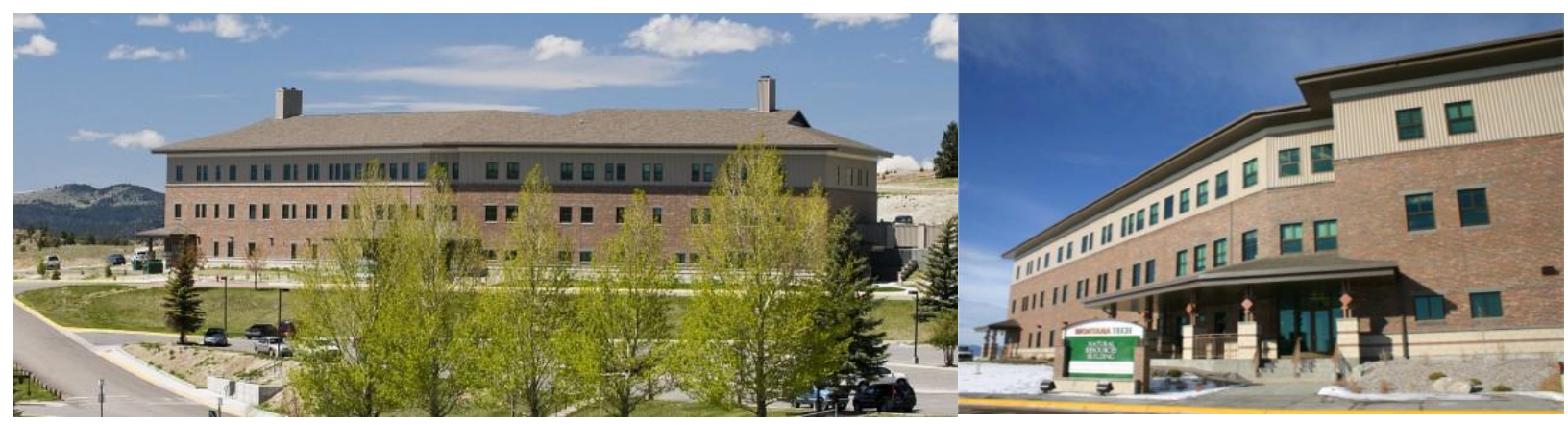

Fig. 1. Natural Resources Building.

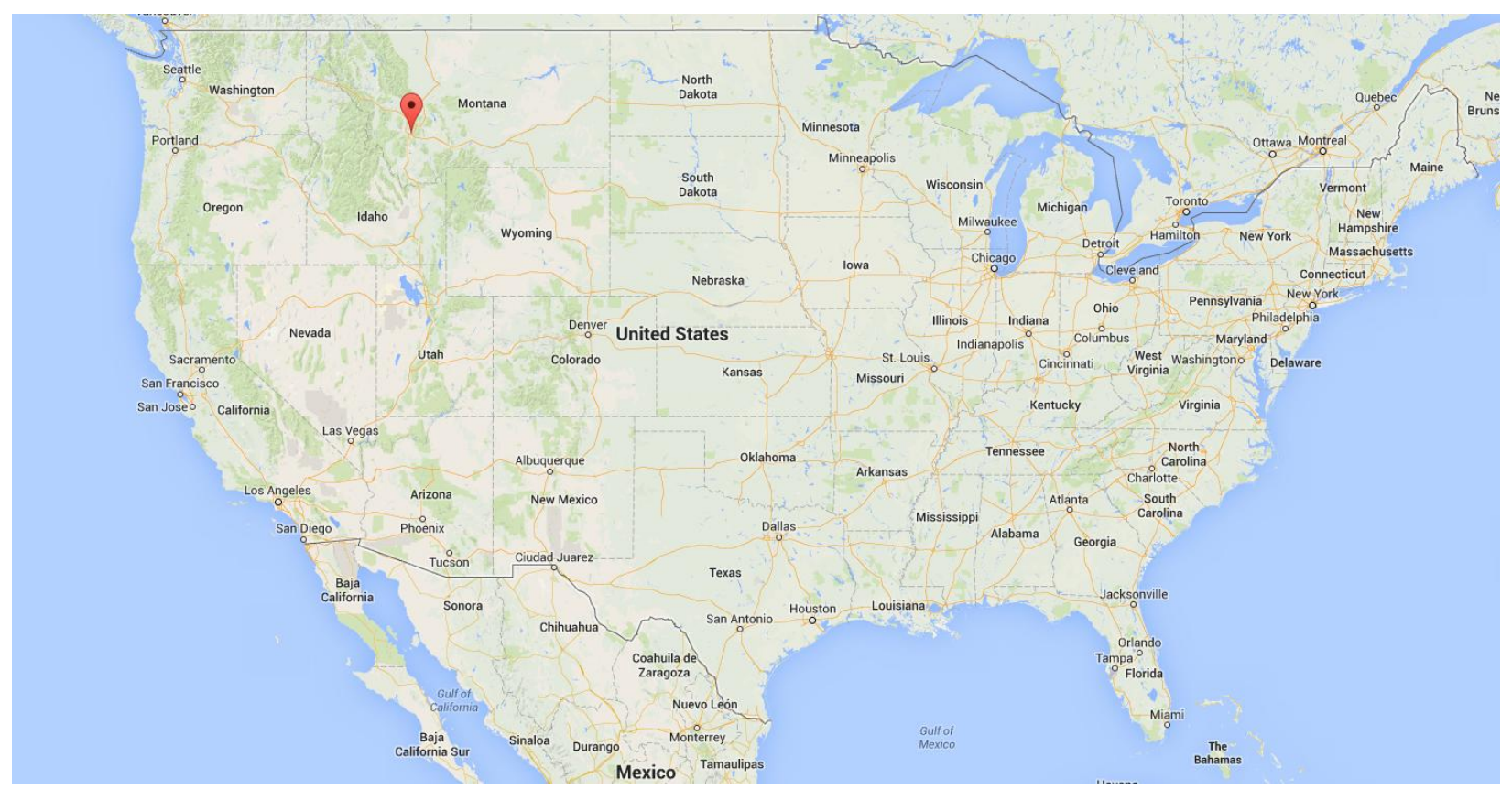

Fig. 2. Geographic location within the United States of the GSHP demonstration site. 


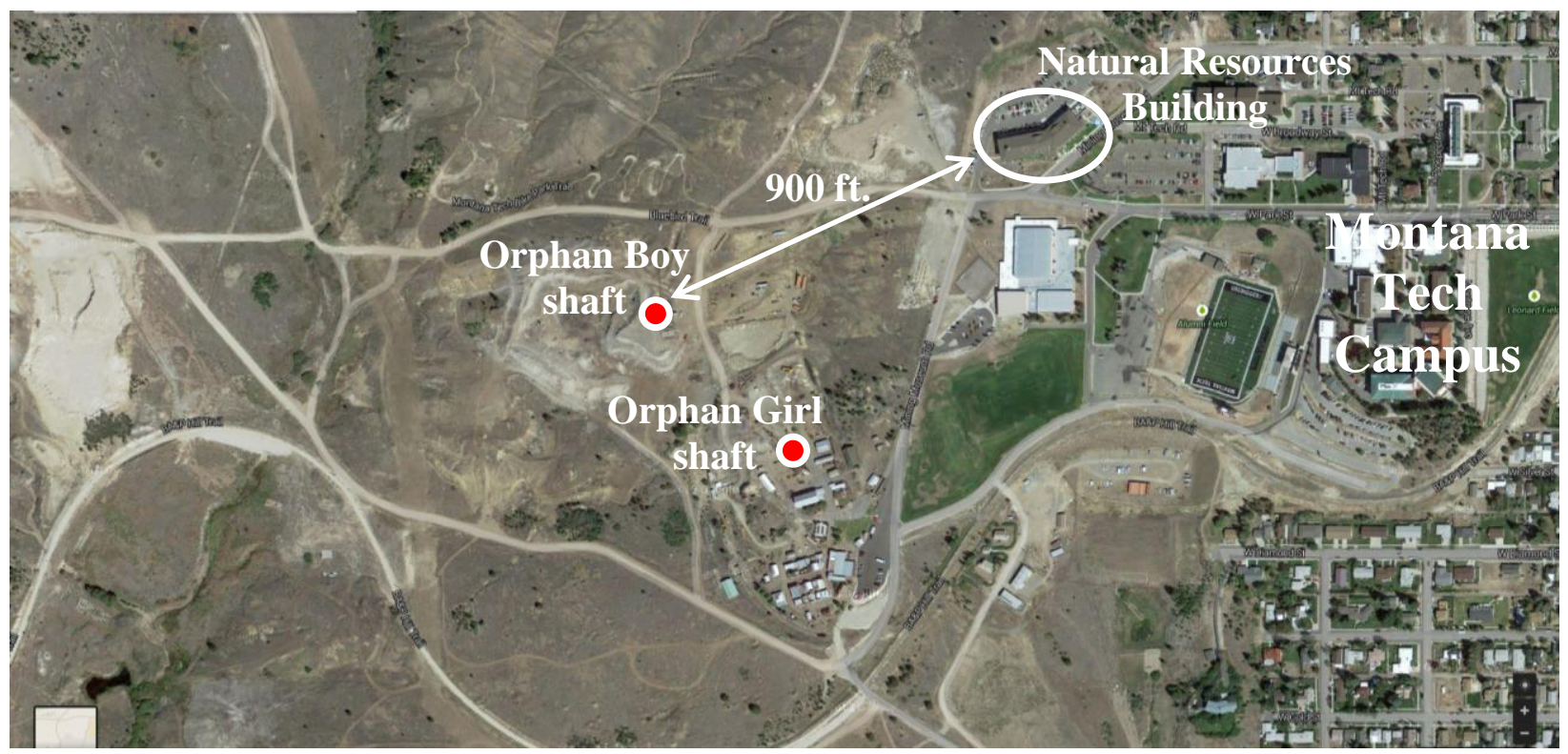

(a)

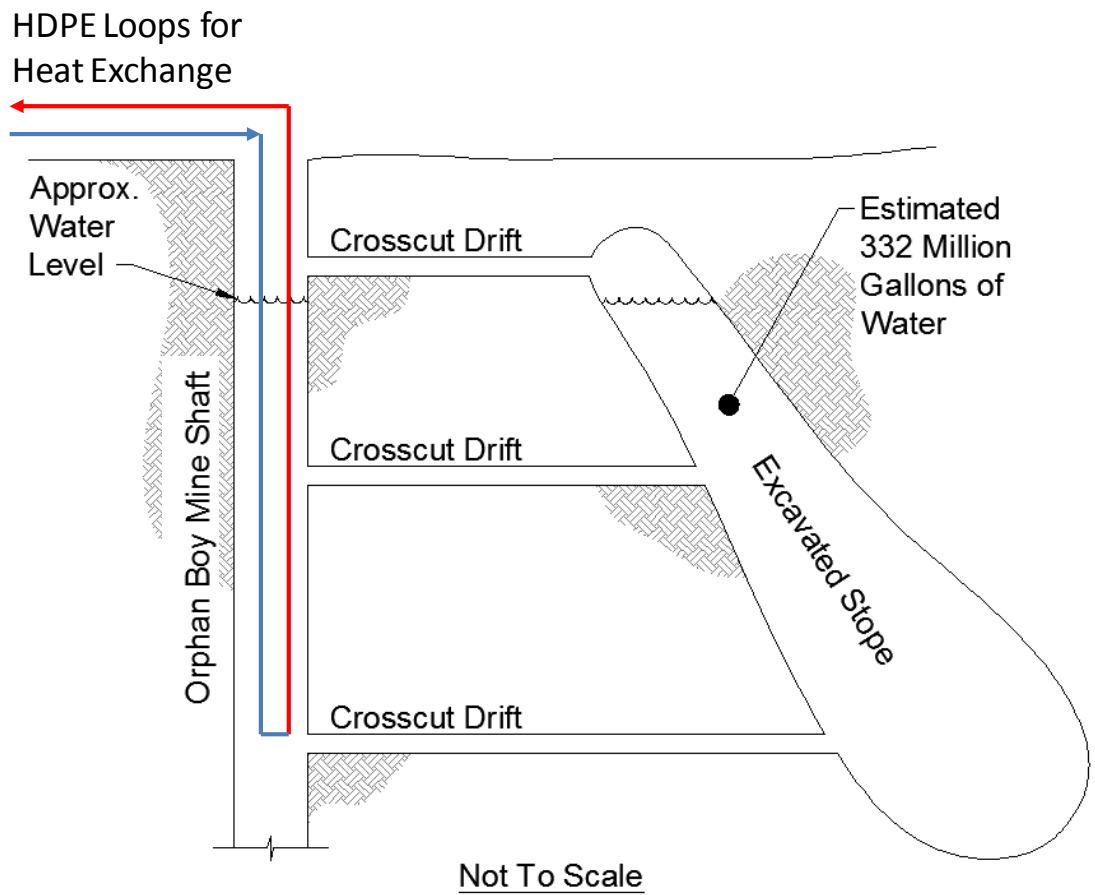

(b)

Fig. 3. GSHP demonstration site: (a) an aerial view and (b) an illustration of Orphan Boy Mine Shaft and the ground heat exchanger.

The goal of this demonstration project is to validate the technical and economic feasibility of the demonstrated commercial-scale GSHP system in the region, and illustrate the feasibility of using mine waters as the heat sink and source for GSHP systems. Should the demonstration prove satisfactory and feasible, it will encourage similar GSHP applications using mine water, thus help save energy and reduce carbon emissions. 
The building and the GSHP system are described in the following sections.

\subsection{Background}

The 10,000 miles of underground tunnels beneath Butte have filled with water since the closure of the Berkeley Pit and, in 1982, the shutoff of groundwater pumps that had dewatered the underground in the past. These waters are typically regarded as a liability, but a new project at Montana Tech is viewing the watery mines of Butte as a potential asset.

The project utilizes some of the advantages that mine waters have over other sources of groundwater. Easy access to mine waters is already afforded by mine shafts, saving the cost of drilling wells. Butte mine waters are also unusually warm; the mine waters used in this project are consistently $78^{\circ} \mathrm{F}\left(25^{\circ} \mathrm{C}\right)$. Additionally, it takes a lot of water to fill 10,000 miles of tunnel, so there is plenty available for geothermal applications.

Montana Tech's Geothermal Technologies Program was awarded an American Recovery \& Reinvestment Act (ARRA) grant by DOE in 2009 to demonstrate low-cost heating in a modern building with GSHPs using water from a nearby mine as the heat exchange medium. The objective of the project was to install a centralized hybrid geothermal system using off-the-shelf technology to reduce the costs of operating Montana Tech's NRB.

During this project, mine waters were accessed via an existing shaft, a closed loop was installed, and a 50 ton water-to-water heat pump was installed to heat and cool the building. The water in the mine is about $78^{\circ} \mathrm{F}\left(25^{\circ} \mathrm{C}\right)$. Nearly 20 years of continuous pumping at a nearby mine has demonstrated that minewater temperatures are stable and ample heat is available for long-term use.

Based on measured data and other relevant information, this case study evaluated performance metrics, including the energy efficiency of the central heat pump equipment and the overall GSHP system; electric end uses of all major equipment of the GSHP system; benefits achieved by the GSHP system (e.g., energy and cost savings, carbon emission reductions) compared with existing systems; and the cost effectiveness of the GSHP installation. This case study also identified areas for further improvement of the GSHP system's energy efficiency, including optimization of the outdoor air (OA) reset control for the hot water supply/return temperature of the building's existing space heating system and the control strategy of the newly added GSHP system.

\subsection{Building Information}

NRB in Montana Tech is a newly constructed 56,000 sq ft research facility that houses the Montana Bureau of Mines and Geology and the Petroleum Engineering Department. The building consists of petroleum labs, classrooms, offices, and computer labs. Building construction began in October 2007 and was completed in December 2009. The building has been occupied since January 2010.

\subsection{HVAC System}

The GSHP system installed at NRB operates in conjunction with an existing steam system (converted to hot water via heat exchangers), which serves multiple buildings on the campus, and an existing air-cooled chiller. Hot and chilled water are distributed throughout the building to various heating and cooling terminals. The new GSHP unit is coupled to both the hot water piping and chilled water piping, and it alternates between heating and cooling modes based on the OA temperature.

In lieu of a well field, the GSHP system uses a flooded underground mine as its heat source and heat sink via a closed-loop ground heat exchanger immersed into the mine water. Figure 2 shows an aerial view of the building site and the location of the mines. 


\subsubsection{Existing System}

Before GSHP system installation, space heating was supplied solely by a steam-to-hot water heat exchanger (steam HX, henceforth). Steam controls for the heat exchanger include two control valves with $2,000 \mathrm{lb} / \mathrm{h}$ and 4,000 $\mathrm{lb} / \mathrm{h}$ capacity. A pressure reduction valve at the steam HX reduces the entering steam pressure from $25 \mathrm{psig}$ to $10 \mathrm{psig}$. The HX is sized to supply up to $310 \mathrm{GPM}$ of $140^{\circ} \mathrm{F}$ hot water (with a $40^{\circ} \mathrm{F}$ temperature differential between the supply and return water to provide $6.2 \mathrm{MMBtu} / \mathrm{h}$ heat to the building). The building hot water pump has a variable speed drive that varies the hot water flow according to the demand for space heating.

Space cooling is supplied solely by a 169 ton air-cooled chiller housed outside the building. The chiller supplies up to 385 GPM of chilled water with a leaving temperature of $45-65^{\circ} \mathrm{F}$. The building chilled water pump also has a variable speed drive that varies the chilled water flow based on the demand for space cooling.

All existing building pumps have both primary and standby pumps that are alternated automatically according to a predefined schedule. Five unitary variable-air-volume (VAV) air-handling units and 80 VAV boxes with hot water reheat are used to condition and distribute warm or cool air to each zone of the building. The VAV boxes modulate their supply air flows (typically can be turned down to $50 \%$ of the design airflow), and with the operation of the reheat coils, maintain the zone temperature setpoints at $75^{\circ} \mathrm{F}$ in summer and $70^{\circ} \mathrm{F}$ in winter. A large amount of laboratory exhaust is present. Two heat recovery units recover heat from the lab hood exhaust to preheat the ventilation air. A few small unit heaters are located in entryways. Also a few zones have baseboard heat.

\subsubsection{GSHP System}

Figure 4 shows the system schematic of the GSHP system. The GSHP system at this facility consists of one 50 ton Multistack (model number MS050XN1H1R0AACR410A; Multistack 2014) water-to-water heat pump. The heat pump provides either hot or chilled water for space conditioning, but not both modes simultaneously. The load-side flow (with the hot or chilled water) of the heat pump is circulated by the existing variable-frequency drive-controlled 10-hp TACO pumps of either the hot or chilled water loop depending on the operation mode of the heat pump.

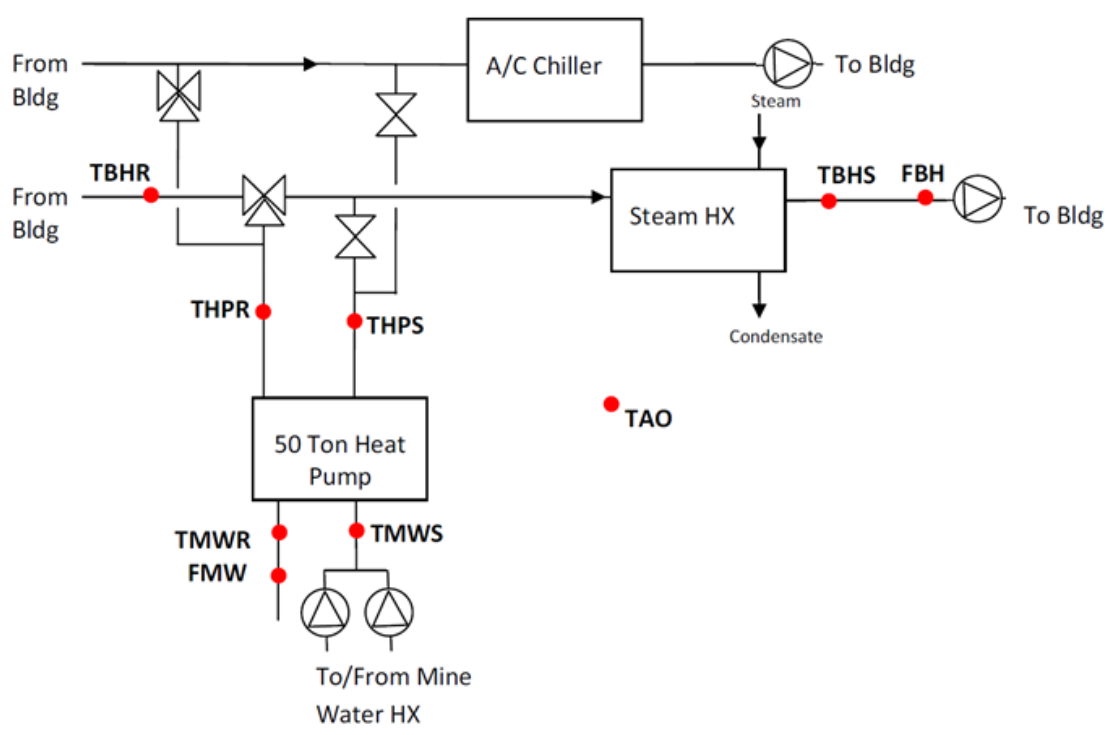

Fig. 4. GSHP system schematic. 
GSHP system operation is controlled as follows:

- The heat pump operates in the heating mode when the $\mathrm{OA}$ temperature is equal to or below $60^{\circ} \mathrm{F}$. In this case, the valves modulate to divert part of the return water of the existing building hot water loop to the load-side of the heat pump, and isolate the connection to the existing building chilled water loop. When a positive flow rate is determined, the heat pump starts to heat up the return water and the heated water then goes back to the building hot water loop before entering the steam HX. The steam HX then adds the remainder of the heat, if it is needed, to maintain the return temperature from the building heating water loop at a set point according to a reset schedule $-135^{\circ} \mathrm{F}$ at $-10^{\circ} \mathrm{F}$ OA temperature, $100^{\circ} \mathrm{F}$ at $60^{\circ} \mathrm{F}$ OA temperature. The remainder of the building hot water distribution system and the heating terminals operate as originally designed during GSHP system operation. Note: When the heating loads are high (i.e., when the ambient temperature is below $-10^{\circ} \mathrm{F}$ ), the resulting $135^{\circ} \mathrm{F}$ return water temperature of the building hot water loop may prevent the heat pump from operating due to the high pressure protection on the heat pump. During those periods, building heating loads are provided by steam HX only.

- The heat pump operates in the cooling mode when the OA temperature is above $60^{\circ} \mathrm{F}$. In this case, the valves modulate to divert part of the return water from the building chiller water loop to the load side of the heat pump, and isolate the connection to the building hot water loop. When a positive flow rate is determined, the heat pump starts and intercepts the chilled water back to the building chilled water loop before it returns to the chiller. The chiller then provides the remainder of the cooling, if it is needed, to maintain the chilled water supply temperature setting of 45 to $65^{\circ} \mathrm{F}$. The remainder of the building chilled water distribution system and the air-handling units operate as originally designed during the GSHP system operation.

\subsubsection{Mine Water System}

The water-to-water heat pump uses a closed-loop GHX immersed in the warm mine waters of the flooded underground Orphan Boy Mine, which is connected at depth with the nearby Orphan Girl Mine (Fig. 3). Together they are considered a single underground reservoir. The water level in the mines is $110-120 \mathrm{ft}$ below the ground surface. The Orphan Boy Mine is located approximately 1,100 ft from NRB. The distance from the mine entrance to the water is $200 \mathrm{ft}$. A set of 6 inch supply and return pipes was installed from the building to the mine. These pipes were extended with 3 inch high-density polyethylene (HDPE) pipes to the $100 \mathrm{ft}$ underground level, where they connected with twenty $3 / 4$ inch $600 \mathrm{ft}$ long HDPE parallel loops, which were lowered into the existing mine shaft and into the mine waters. Two redundant $7.5 \mathrm{hp}$ constant-speed TACO pumps to circulate water in the ground loop are housed on the second floor of NRB. The ground loop pumps operate in conjunction with the existing pumps in the building hot and chilled water loops for the operation of the heat pump unit.

\subsection{Data Collection}

As part of the original design, the building's heating and cooling system was equipped with a direct digital control system, called NiagaraAX, for the measurement and control of the system. During the installation of the GSHP system, the existing control system was extended to include some measurements for the ground loop and the heat pump. Performance data on the GSHP system as well as the building hot and chilled water loop are collected through the direct digital control system at Montana Tech. NiagaraAX polls the sensors once per second and provides 15 minute totals or averages of each sensor depending on the sensor type. Table 1 provides the list of data points, among which measurements for the mine water pump power (WMWP in Table 1), heat pump loop flow (FHP), building heating loop blended temperature (TBHB), and building cooling loop data (TBCS, TBCR, TBCB, and FBC) were unavailable. 
Table 1. GSHP system monitoring points

\begin{tabular}{|c|c|c|c|}
\hline No. & Data Point & Description & Units \\
\hline \multicolumn{4}{|c|}{ Ground Loop (coupled to Mine Water) } \\
\hline 1 & TMWS & Mine Water Loop Supply Temperature & $\operatorname{deg} \mathrm{F}$ \\
\hline 2 & TMWR & Mine Water Loop Return Temperature & $\operatorname{deg} \mathrm{F}$ \\
\hline 3 & FMW & Mine Water Loop Flow & GPM \\
\hline 4 & WMWP & Mine Water Pump Power & $\mathrm{kW} / \mathrm{kWh}$ \\
\hline \multicolumn{4}{|c|}{ Heat Pump Building Loop } \\
\hline 5 & THPS & HP Loop Supply Temperature & $\operatorname{deg} \mathrm{F}$ \\
\hline 6 & THPR & HP Loop Return Temperature & $\operatorname{deg} \mathrm{F}$ \\
\hline 7 & FHP & HP Loop Flow & GPM \\
\hline \multicolumn{4}{|c|}{ Building Heating Loop } \\
\hline 8 & TBHS & Building Heating Loop Supply Temperature (After Steam HX) & $\operatorname{deg} \mathrm{F}$ \\
\hline 9 & TBHR & Building Heating Loop Return Temperature & $\operatorname{deg} \mathrm{F}$ \\
\hline 10 & TBHB & Building Heating Loop Blended Temperature (Before Steam HX) & $\operatorname{deg} \mathrm{F}$ \\
\hline 11 & FBH & Building Heating Loop Flow & GPM \\
\hline \multicolumn{4}{|c|}{ Building Cooling Loop } \\
\hline 12 & TBCS & Building Cooling Loop Supply Temperature (After Chiller) & $\operatorname{deg} F$ \\
\hline 13 & TBCR & Building Cooling Loop Return Temperature & $\operatorname{deg} \mathrm{F}$ \\
\hline 14 & TBCB & Building Cooling Loop Blended Temperature (Before Chiller) & $\operatorname{deg} \mathrm{F}$ \\
\hline 15 & FBC & Building Cooling Loop Flow & GPM \\
\hline \multicolumn{4}{|c|}{ Ambient Conditions } \\
\hline 16 & $\mathrm{TAO}$ & Ambient Temperature & $\operatorname{deg} \mathrm{F}$ \\
\hline \multicolumn{4}{|c|}{ Total Facility } \\
\hline 17 & WT & Total Building Power & $\mathrm{kW} / \mathrm{kWh}$ \\
\hline
\end{tabular}

Figure 4 shows the location of data collection points currently available, which include ground loop supply and return water temperature and flow rate, heat pump load-side supply and return water temperatures, building hot water loop supply and return water temperatures and flow rate, OA temperature, and total building power. 


\section{ANALYSIS OF MEASURED DATA}

Performance data on the GSHP system is available as of January 2014. Performance data from January 1 through July 31, 2014 have been analyzed in this study. The measured data were analyzed to 1) assess the operational efficiency of the heat pump and the overall GSHP system, 2) assess the operation of the pump, and 3) identify faults/abnormalities in GSHP system operation and determine potential improvements to the GSHP system. GSHP system performance is evaluated by analyzing the trend of measured water temperature in the ground loop and heat pump building (load-side) loop, and by calculating heat transfer in the ground loop and the heat pump building loop, pump and heat pump energy use, operational efficiency of the heat pump, and finally, overall GSHP system efficiency.

\subsection{Measured Water Temperature Trend and Flow Rate}

Measured performance data were visualized through a series of plots. These plots can help us understand the operation of the installed GSHP system, identify periods when the system was not operating, and pinpoint the factors that resulted in conditions not suitable for its operation. This allowed filtering out of the invalid measured data when deriving the GSHP system operating performance parameters, while at the same time suggesting GSHP system and control improvements to maximize energy savings.

\subsubsection{Ground Loop (Heat Pump Source-Side Loop)}

The ground loop supply and return water temperature and flow rate and the OA temperature during January-July are shown in Fig. 5. The measured flow rate suggests that the GSHP system was operating only during January-April, intermittently, and in July. The measured flow rates were $82-90 \mathrm{gpm}$ most of the time, 64-77 gpm and 50-54 gpm some of the time, and 33-43 gpm for brief periods.

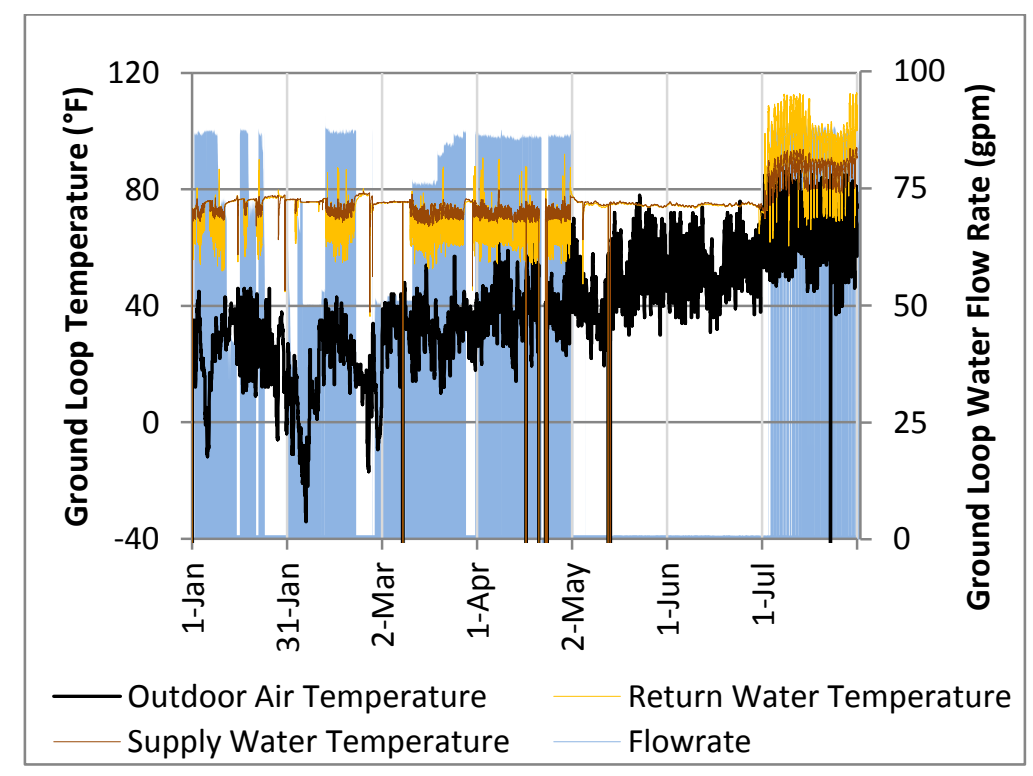

Fig. 5. Ground loop water temperature and flow rate.

During January-April, the ground loop supply water temperature (i.e., water entering the heat pump) ranged between $67.3^{\circ} \mathrm{F}$ and $79.8^{\circ} \mathrm{F}$, and between $75.3^{\circ} \mathrm{F}$ and $94.3^{\circ} \mathrm{F}$ in July. The ground loop return water temperature (i.e., water leaving the heat pump) ranged between $52^{\circ} \mathrm{F}$ and $92.1^{\circ} \mathrm{F}$ during January-April, and between $60.6^{\circ} \mathrm{F}$ and $113.1^{\circ} \mathrm{F}$ in July. 
The OA temperature fluctuated widely, more so during the winter. The temperature of ground loop supply water was stable and was about $40^{\circ} \mathrm{F}$ higher than OA during most of the 4-month heating period. On the other hand, in July, the mine water was warmer than the OA. This suggests that during the summer at this location, using mine water as a heat sink for cooling may not offer any gain in energy efficiency compared with the air-cooled chiller.

Figure 6 shows the ground loop temperature differential (TD). The mine water acted as a heat source during January-April (with brief transient periods and as both heat source and heat sink in July). As a heat source, the ground loop provided $8-12^{\circ} \mathrm{F}$ TD for most periods and with an average TD of $8.5^{\circ} \mathrm{F}$. As a heat sink, the ground loop provided $8-12^{\circ} \mathrm{F}$ TD for most periods and $15-18^{\circ} \mathrm{F}$ TD for some periods, which averaged $11.7^{\circ} \mathrm{F}$. During July $17-29$, the ground loop provided a smaller TD, which corresponded to unusual heat pump operation during this period when the heat pump building loop water temperature was observed to float [see Fig. 10(b)].

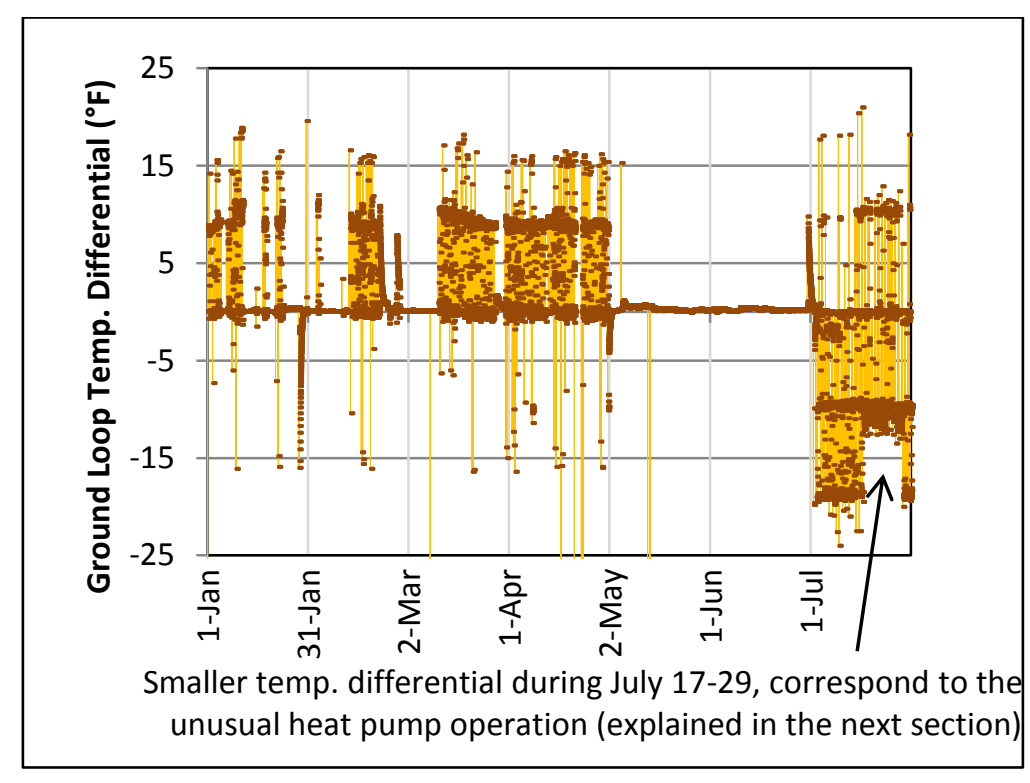

Fig. 6. Ground loop temperature differential.

Figures 5 and 6 show several periods with smaller-than-expected measured flow rate or TD in the ground loop. It is important to investigate whether during these periods the GSHP system was actually operating and the measured data is valid for use in deriving GSHP system operating performance parameters. To accomplish this, a scatter plot of ground loop TD versus flow rate was created, as shown in Fig. 7. This figure shows several data points when either noticeable difference in the ground loop supply and return water temperature was detected with no flow rate (data points A), or a noticeable flow rate was detected with very small TD (data points B). These data points indicate the periods when (a) the entire GSHP system (including the ground loop pump) was shut off but the temperature sensors were sensing the temperature of the standing water in the ground loop, or (b) the heat pump was shut off but the sourceside (ground loop) pump was still running. A close inspection of Fig. 7 indicates that the GSHP system was running under normal operation with reasonable TD when the ground loop water flow rate was 64 gpm or above. Therefore, the measured data for both of these periods will be excluded from further analysis. During these periods, data points with TD less than $1^{\circ} \mathrm{F}$ (mostly occurred during the short transient period at the beginning or end of a heat pump operation cycle) will also be ignored. 


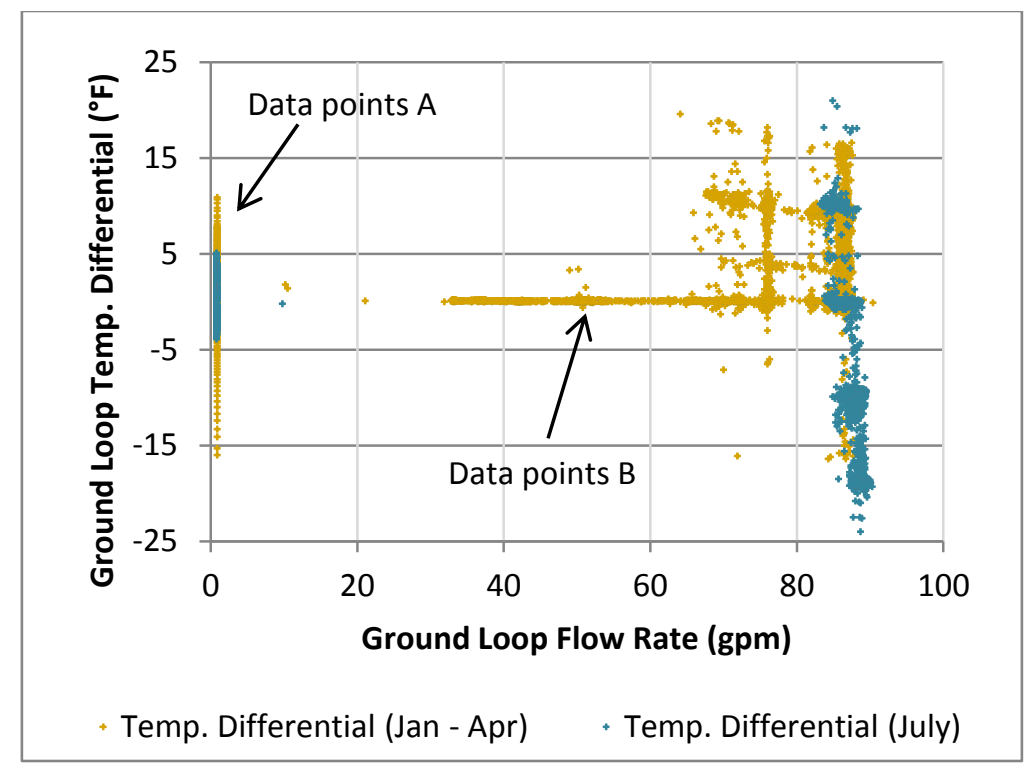

Fig. 7. Ground loop water temperature differential versus flow rate.

It is also important to closely inspect the mine water temperature to identify any seasonal trend or the impact of heat extraction or rejection by the GSHP system. A scatter plot of ground loop supply and return water temperature versus OA temperature in Fig. 8 shows stable ground loop supply water temperature during January-April. However, in July, the mine water temperature shows increasing trend as the outdoor air becomes warmer. With no variation detected in the mine water temperature in the winter and only a month-long period of measured data in the summer, it is difficult to conclude if the mine water temperature rise in the summer is caused by the weather and/or the heat rejection from the ground loop. Further discussion in Section 2.3.1 about the total heat extracted and rejected by the ground loop during the measurement period explores this aspect.

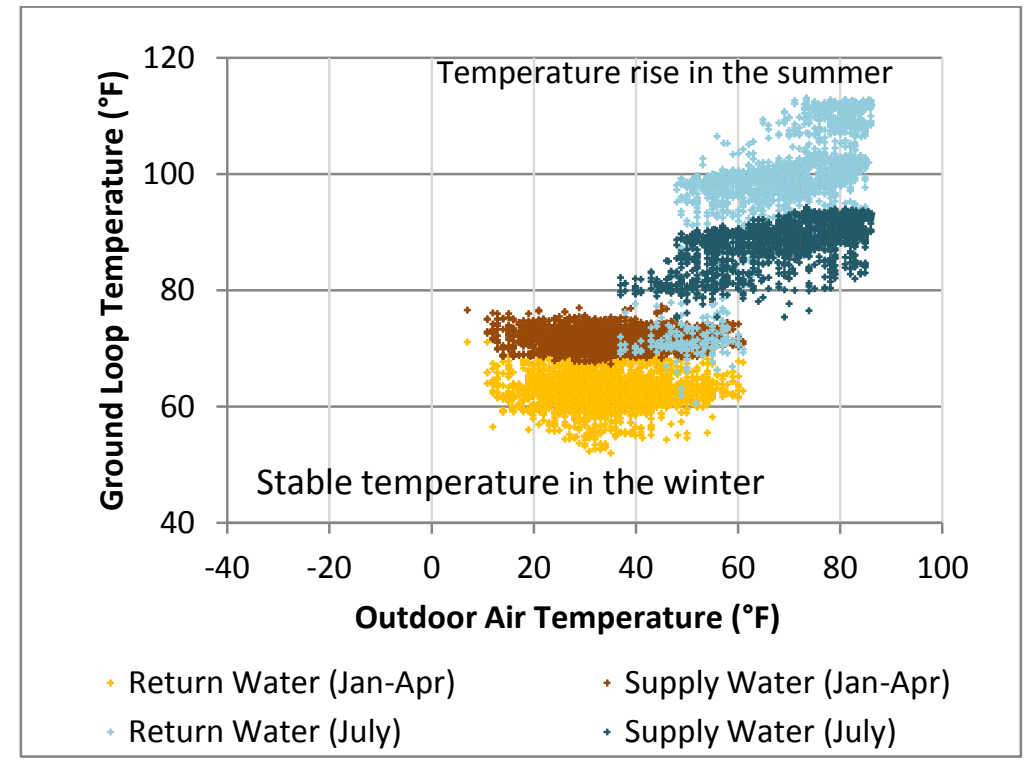

Fig. 8. Ground loop water temperature versus outdoor air temperature (excluding invalid data). 


\subsubsection{Heat Pump Load-Side Loop}

The heat pump load side (also referred to as "building loop" elsewhere in this report) supply and return water temperature and the OA temperature during January-July are shown in Fig. 9. The measured temperature of water entering the heat pump (THPR) ranged between $100.8^{\circ} \mathrm{F}$ and $148.8^{\circ} \mathrm{F}$ during January-April, and between $42.1^{\circ} \mathrm{F}$ and $129.1^{\circ} \mathrm{F}$ in July. The measured heat pump supply water temperature (THPS) ranged between $89^{\circ} \mathrm{F}$ and $148.8^{\circ} \mathrm{F}$ during January-April, and between $41.9^{\circ} \mathrm{F}$ and $140.6^{\circ} \mathrm{F}$ in July.

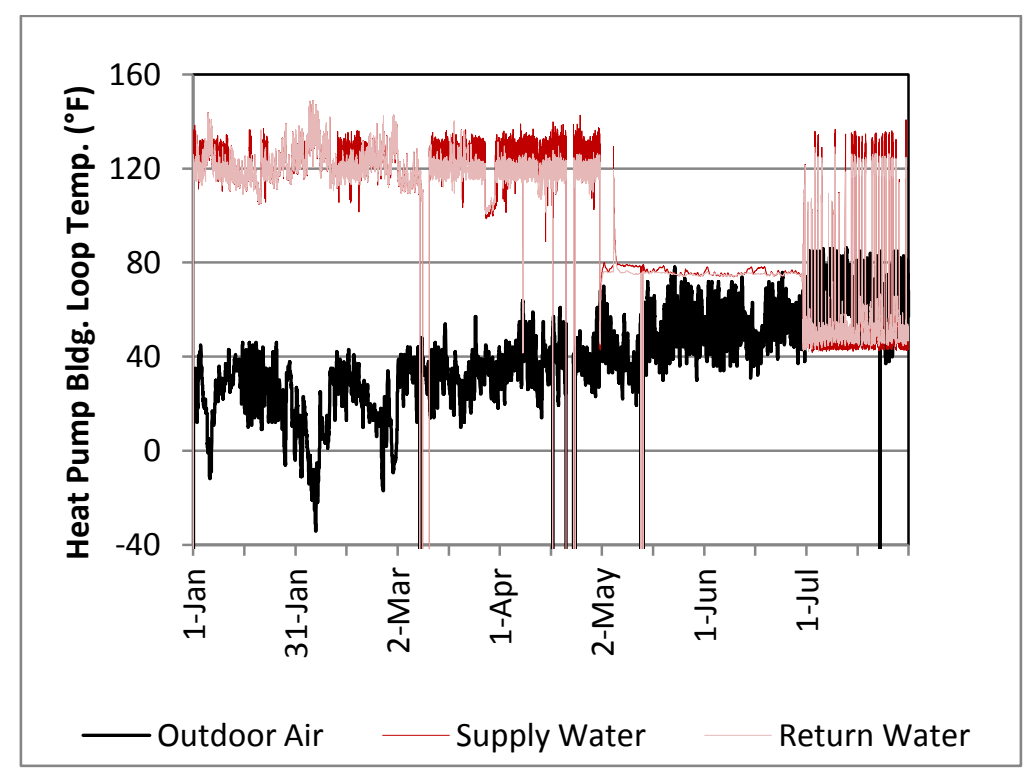

Fig. 9. Heat pump load-side loop water temperature.

Of note is that the maximum of the supply and return water temperature ranges during January-April are equal. A close inspection of Fig. 9 shows that data points at the higher return hot water temperature show the same supply temperature, which indicates no heat delivery by the heat pump during these periods (heat pump was not in operation). Further investigation of the heat pump load-side loop TD is needed to determine the supply and return water temperature range when the heat pump was operating.

Figure 10a shows the heat pump load-side loop TD during January-July. As expected, data points with high return water temperature during January-March in Fig. 9 show a nearly zero TD, meaning that the heat pump was operating intermittently during January-March. In the heating mode, the heat pump provided $6-15^{\circ} \mathrm{F}$ TD for most periods, averaging $10^{\circ} \mathrm{F}$. In the cooling mode, the heat pump provided $1-$ $7^{\circ} \mathrm{F}$ TD, averaging $3.8^{\circ} \mathrm{F}$. During July $17-29$, a smaller TD was observed. Close inspection of this period in Fig. 10b reveals that during this period, the heat pump building loop water temperature was floating with the OA temperature. The reason for this unusual operation is unknown. 

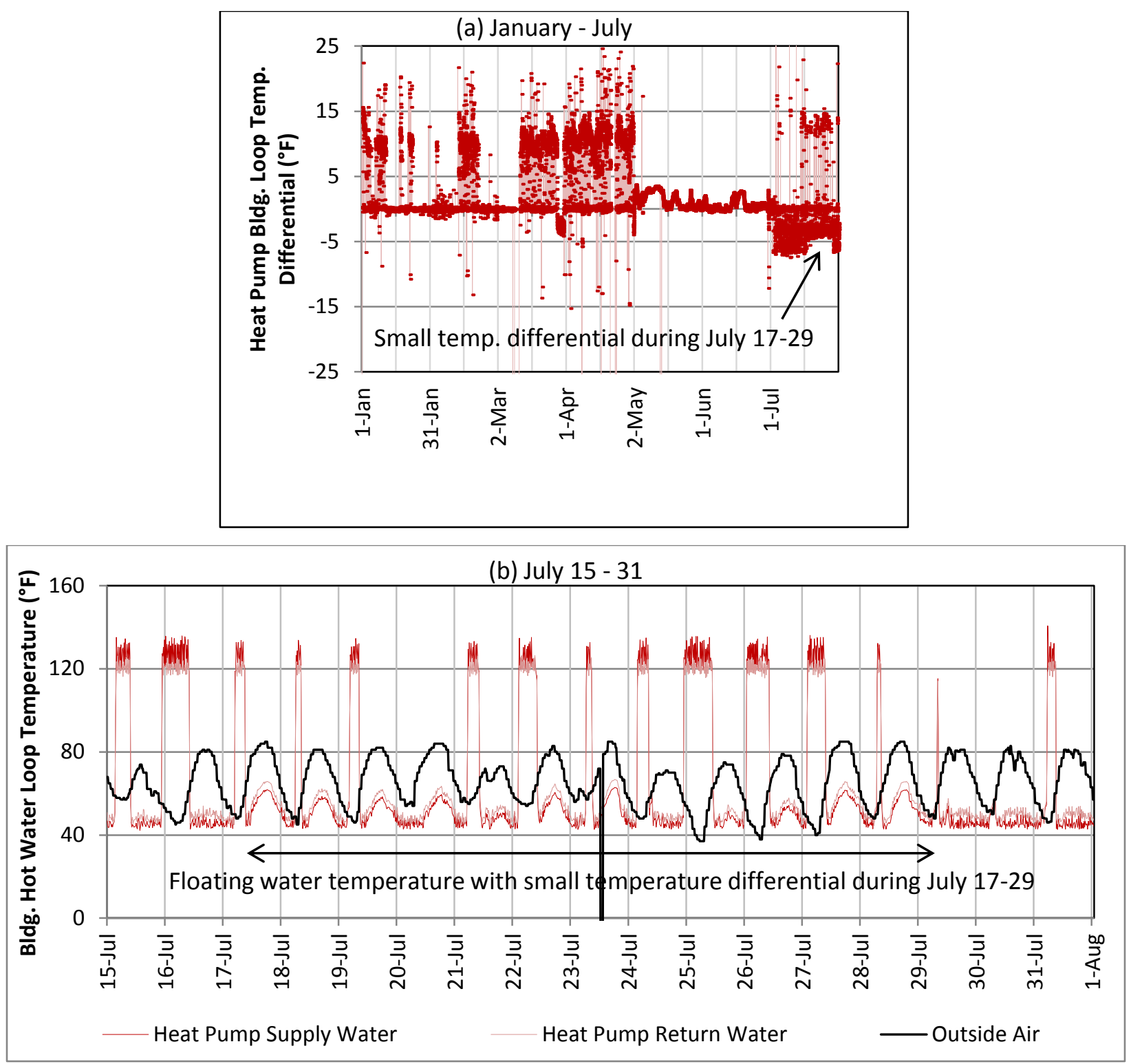

Fig. 10. Heat pump load-side loop temperature differential.

To determine the return water temperature when the heat pump ceased to operate, a scatter plot of TD versus return water temperature is shown in Fig. 11. Note that when the return water temperatures were above $124^{\circ} \mathrm{F}$, the TD is almost zero (data points A). These data points correspond to periods when the heat pump did not run because the return water temperature exceeded the limit at which a heat pump can operate. Also, even when the return water temperatures were within the normal heat pump operating conditions, the TDs in the heating and cooling mode were sometimes almost zero (data points B). These data points likely correspond to periods when the heat pump was manually shut off. 


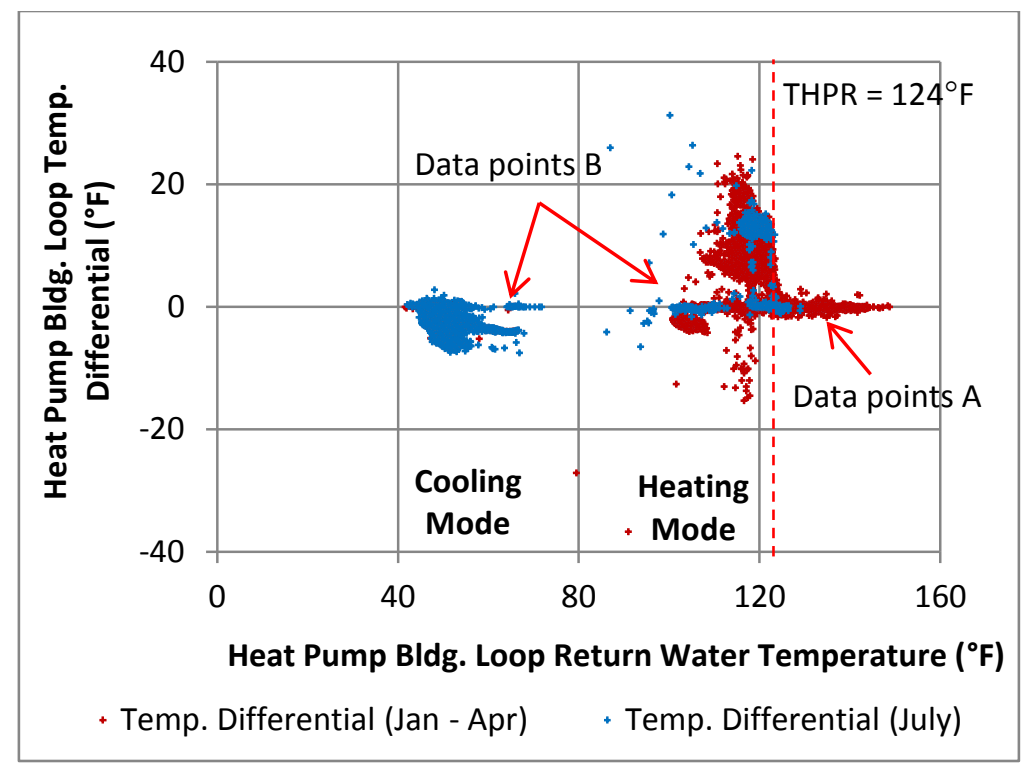

Fig. 11. Heat pump load-side loop temperature differential versus return water temperature.

Using these criteria to exclude the data points when heat pump was not operating, it was found that in the heating mode, the temperature of water entering the heat pump ranged between $106.9^{\circ} \mathrm{F}$ and $124.6^{\circ} \mathrm{F}$ during January-April, and between $95.6^{\circ} \mathrm{F}$ and $123.4^{\circ} \mathrm{F}$ in July. The heat pump supply hot water temperature ranged between $114^{\circ} \mathrm{F}$ and $142.6^{\circ} \mathrm{F}$ during January-April, and between 102.8 and $140.6^{\circ} \mathrm{F}$ in July. ${ }^{1}$

To investigate the influence of OA temperature on the heat pump load-side loop water temperature, a scatter plot of supply and return water temperature versus OA temperature is shown in Fig. 8 (excluding the data points when heat pump was not operating).

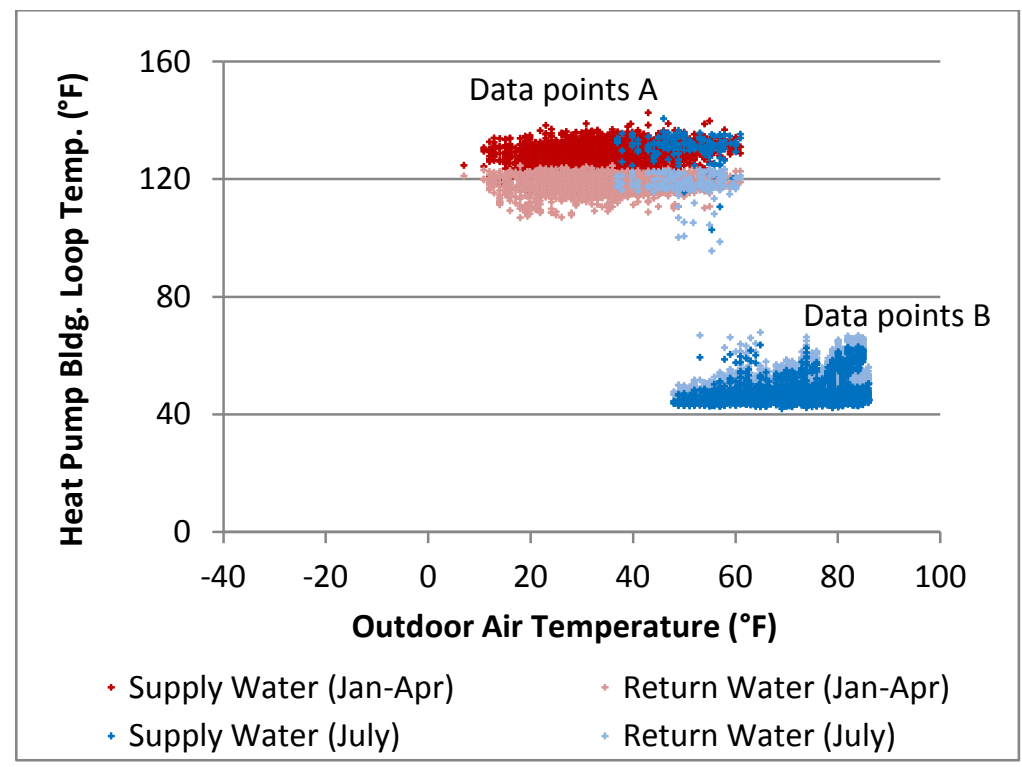

Fig. 12. Heat pump load-side loop water temperature versus outdoor air temperature.

\footnotetext{
${ }^{1}$ The heat pump provided heating in July when the OA temperature dropped below $60^{\circ} \mathrm{F}$ down to $37^{\circ} \mathrm{F}$ at night.
} 
In the heating mode during January-April and July, the supply and return water temperature do not indicate any correspondence with the OA temperature (data points A). ${ }^{2}$ In the cooling mode in July, the supply water temperature sometimes rose to $60^{\circ} \mathrm{F}$ during warmer weather, which is unexpected (data points B). A close inspection showed that this occurred during July 17-29 afternoons. During this period, the heat pump building loop water temperature was floating [see Fig. 10(b)], still delivering heating at night (with $13^{\circ} \mathrm{F}$ TD) and cooling in the afternoon (with a smaller TD). It is likely that an OA reset control for the chilled water supply temperature of the air-cooled chiller was in effect during these time periods.

\subsubsection{Building Hot Water Loop}

The building hot water loop supply and return water temperature, water flow rate, and outdoor air temperature during January-July are shown in Fig. 13. Note that heating was provided also in July. The supply hot water temperature (TBHS) ranged between $90^{\circ} \mathrm{F}$ and $168.2^{\circ} \mathrm{F}$. The return hot water temperature (TBHR) ranged between $81.1^{\circ} \mathrm{F}$ and $148.5^{\circ} \mathrm{F}$. The flow rate data indicated variable flow in the hot water loop with a minimum of $100 \mathrm{gpm}$, with higher flow rate in the winter and lower flow rate in the summer. Further investigation reveals the correspondence between the flow rate and TD of the building hot water loop (Fig. 15).

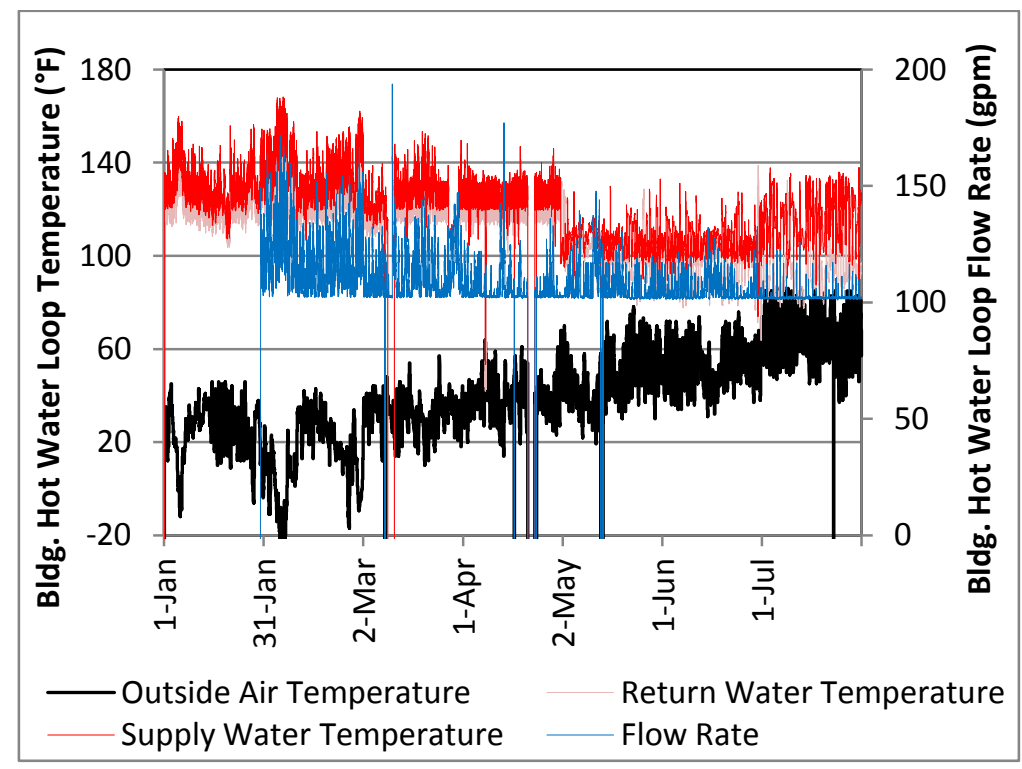

Fig. 13. Building hot water loop temperature and flow rate.

Figure 14 shows the building hot water loop TD and flow rate. The hot water loop provided up to $25^{\circ} \mathrm{F}$ TD for most periods in the winter. In the summer, two clusters of TD were observed, a smaller TD up to $10^{\circ} \mathrm{F}$ (data points $\mathrm{A}$ ) and a higher TD approaching $50^{\circ} \mathrm{F}$ (data points $\mathrm{B}$ ).

\footnotetext{
${ }^{2}$ It is noted in Section 2.1.2 that the building hot water loop return water temperature is controlled according to an OA reset schedule. However, at higher building hot water loop return temperature, the heat pump ceases to operate (i.e., heat pump was operating when the return water temperature was close to the higher outside air temperature limit of the reset schedule). Therefore, any impact from OA reset control is not observed on the heat pump load-side loop water temperature.
} 


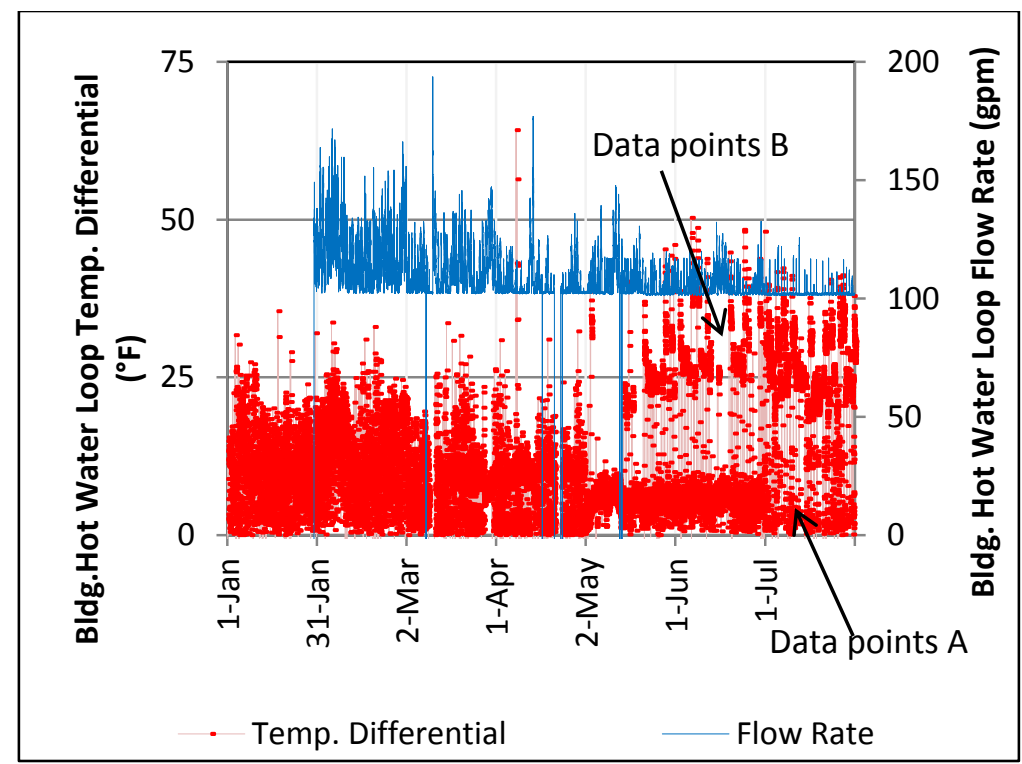

Fig. 14. Building hot water loop temperature differential.

To further investigate the two clusters, Fig. 15 shows a scatter plot of building hot water loop TD and flow rate versus OA temperature. Note that the hot water loop flow rate was relatively small during MayJuly and the minimum (i.e., $100 \mathrm{gpm}$ ) occurred when OA temperatures were above $65^{\circ} \mathrm{F}$. Data points A correspond to building main heating loads during the winter and at night during the summer. Data points $\mathrm{B}$ correspond to the reheating loads during warmer weather when space cooling was needed in the building. Apparently, when the heat pump was providing nearly constant 50 ton cooling during daytime in the summer, the steam HX had to be operated to provide reheat to certain VAV terminal units in the building to maintain room temperatures at the set point. The minimum flow rate of $100 \mathrm{gpm}$ combined with high TD corresponds to these periods, when the hot water loop was providing reheat.

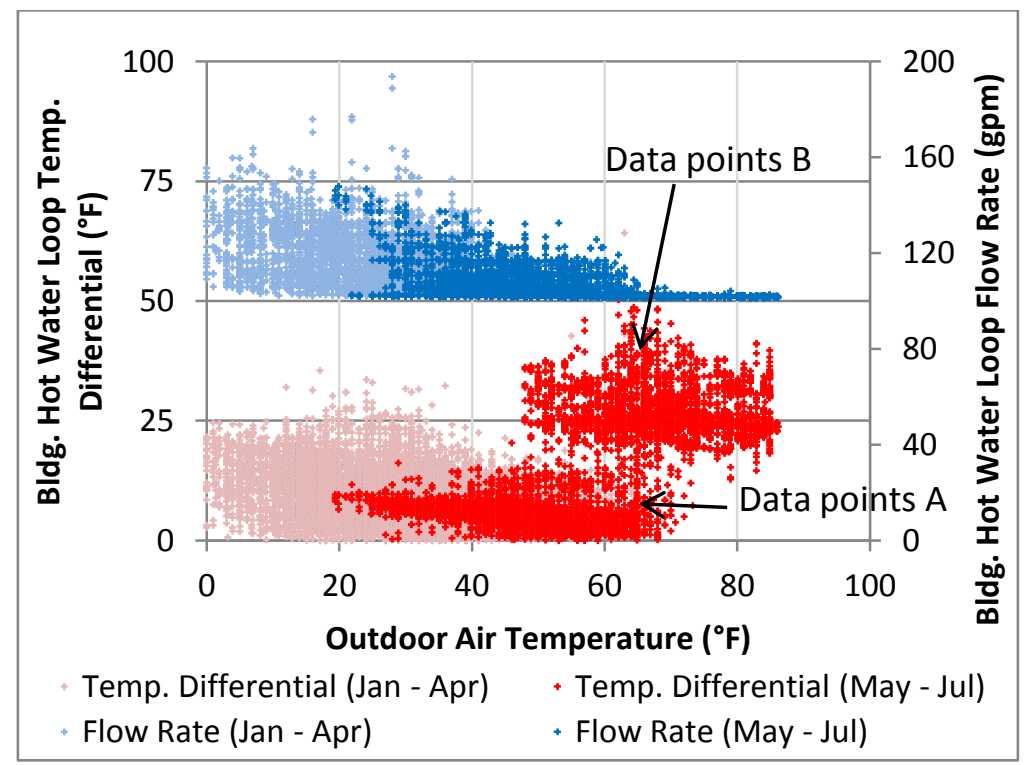

Fig. 15. Building hot water loop temperature differential and flow rate versus outdoor air temperature. 
The building hot water loop return water temperature is controlled according to an OA reset schedule$135^{\circ} \mathrm{F}$ at $-10^{\circ} \mathrm{F}$ OA temperature, $100^{\circ} \mathrm{F}$ at $60^{\circ} \mathrm{F}$ OA temperature, and linear decrease in the between. To verify the operation of OA reset control, a scatter plot of building hot water loop temperature and OA temperature is shown in Fig. 16. Of note is that the return water temperature did not follow the reset schedule at warmer OA temperatures (data points $\mathrm{C}$ ) and when $\mathrm{OA}$ temperatures were above $60^{\circ} \mathrm{F}$ (data points D).

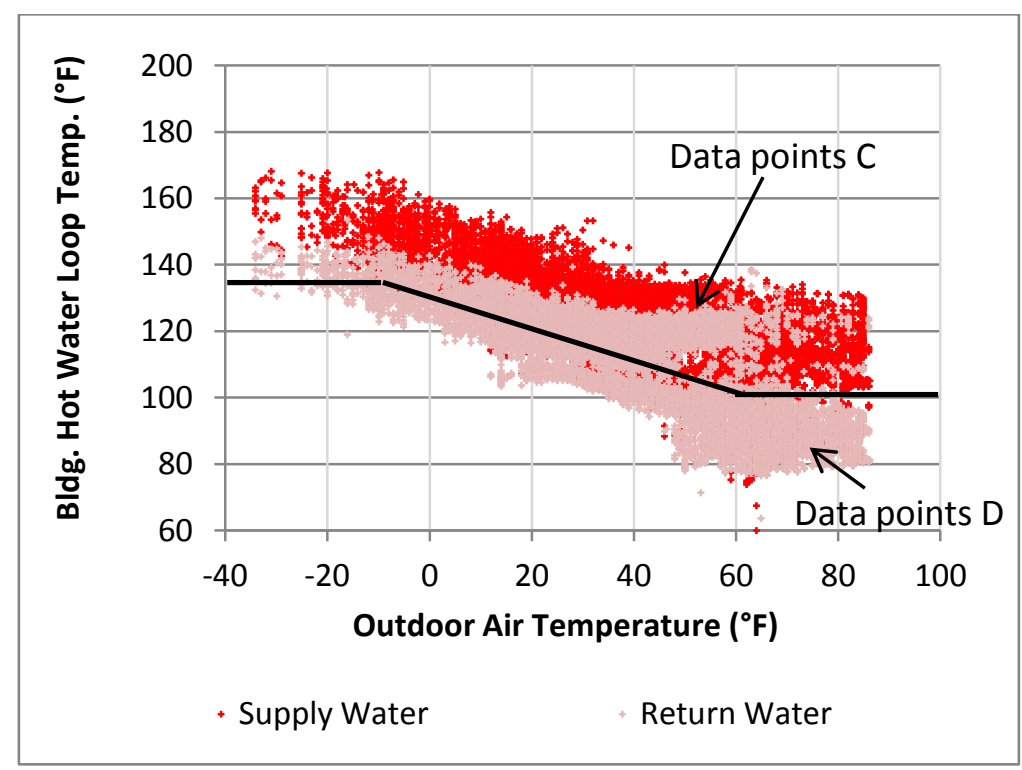

Fig. 16. Building hot water loop temperature versus outdoor air temperature.

For data points $\mathrm{C}$ in Fig. 16, plotting coincident heat pump building loop water temperature in Fig. 17 reveals that these data points correspond to periods when the heat pump was operating and governing the building hot water loop temperature.

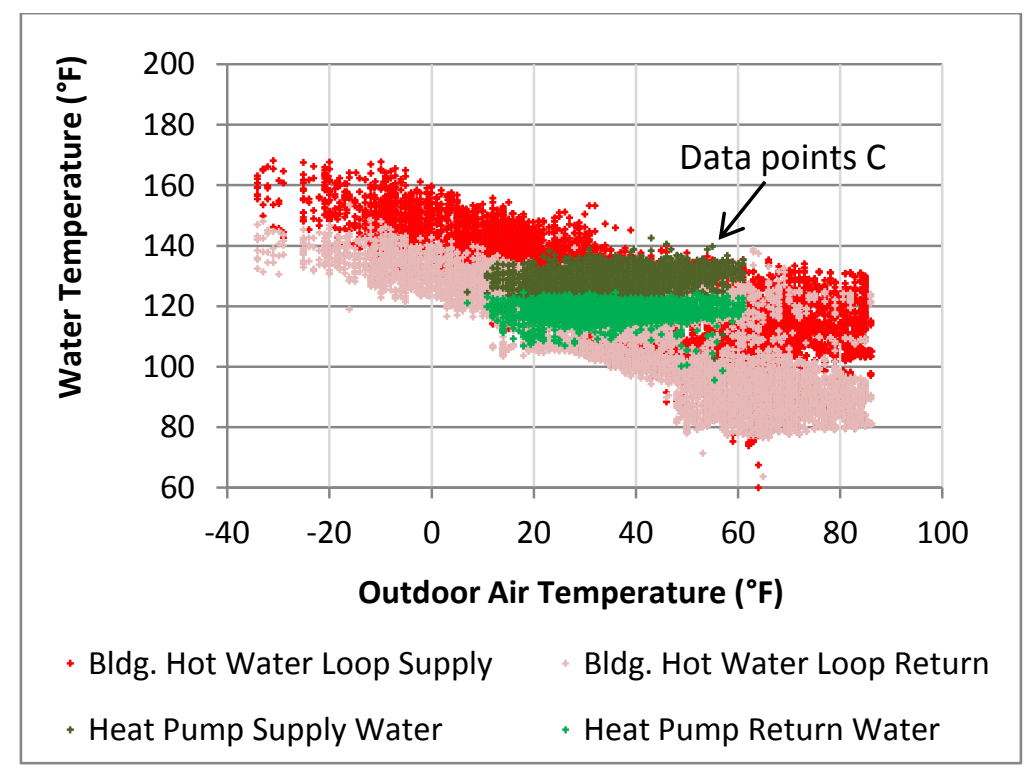

Fig. 17. Building hot water loop and heat pump building loop water temperature versus outdoor air temperature. 
Data points D in Fig. 16 correspond to operation in the summer when cooling loads are coupled with the need for reheat (data points B in Fig. 15). To closely investigate this operation, Fig. 18 shows a weeklong snapshot of building hot water loop temperature during heat pump operation in the cooling mode. It shows the building hot water loop supply and return temperatures, heat pump supply and return water temperatures, and OA temperature. Apparently, the heat pump was operating in the cooling mode (indicated by the near $40^{\circ} \mathrm{F}$ supply temperatures) during daytime and in the heating mode (indicated by the above $120^{\circ} \mathrm{F}$ supply temperatures) at night when the outdoor air temperature dropped below $60^{\circ} \mathrm{F}$. During daytime, when the heat pump was operating in the cooling mode, the steam system had to provide reheat, which was indicated by the $>100^{\circ} \mathrm{F}$ supply temperature of the building hot water loop and the coincidentally high TD, which as discussed earlier is due to the low hot water loop flow rate.

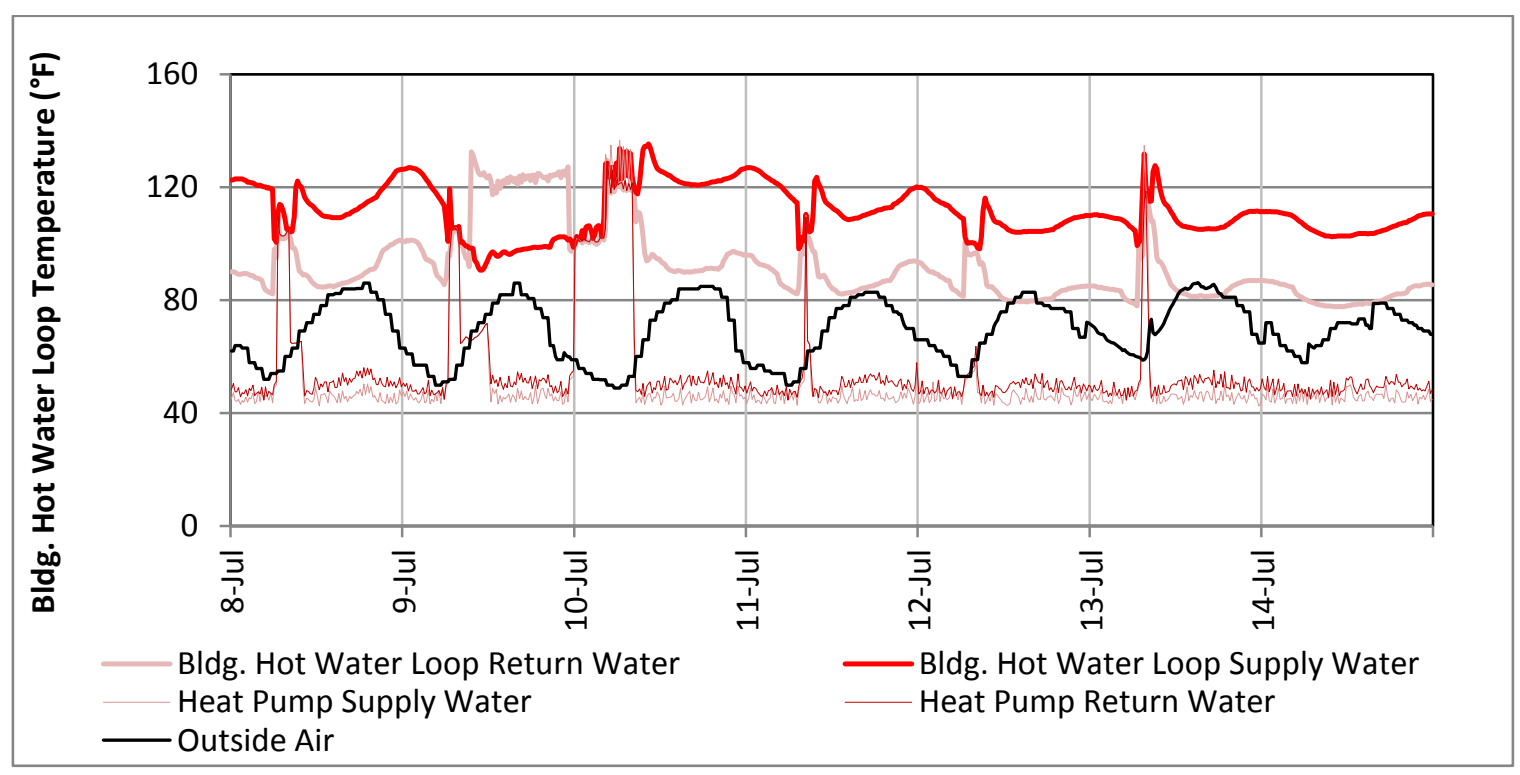

Fig. 18. Building hot water loop temperature during heat pump operation in the cooling mode (July 8-15).

\subsection{Period of GSHP System Operation}

Observations in Section 2.1 helped identify periods for which the measured data is valid and conditions that must be accounted for while making full-year predictions of GSHP system performance. The remaining data must be filtered out.

As shown in Fig. 5, the ground loop pump operated intermittently during January-March, continuously in April, remained off for the entire months of May and June, and then operated continuously in July. Clearly, the GSHP system was off when the ground loop pump was not operating. However, apparently, operation of the ground loop pump was independent of operation of the heat pump. At times, the ground loop pump was operating but the heat pump was shut off. ${ }^{3}$ These periods can be explained through the following scenarios and are marked in Fig. 19 (a scatter plot of ground loop flow rate versus building hot water loop return temperature) and Fig. 20 (a scatter plot of ground loop and heat pump building loop TD) versus building hot water loop return temperature:

(a) As shown in Fig. 7, the heat pump was off (indicated by very small ground loop TD), when the ground loop water flow rate was below 64 gpm (see data points A in Fig. 19).

\footnotetext{
${ }^{3}$ This wasted pumping energy, which is undesirable. If the heat pump unit is off, the ground loop pump and the three-way valves in the building hot/chilled water loop shall also be turned off to avoid wasting pumping energy.
} 
(b) As shown in Fig. 11, the heat pump could not operate when the building hot water loop return water temperature was above $124^{\circ} \mathrm{F}$. This means that even at a ground loop flow rate above $64 \mathrm{gpm}$, the heat pump could not operate when the building hot water loop return water temperature was above $124^{\circ} \mathrm{F}$ (see data points B in Fig. 19).

(c) There were few periods when the ground loop flow rate was $64 \mathrm{gpm}$ or above and the building hot water return temperature was $124^{\circ} \mathrm{F}$ or below, but the heat pump did not operate (as indicated by data points in Fig. 20. The reason for such operation is unknown, but it is likely that the heat pump was shut off then for maintenance or other reasons.

(d) During these periods, the ground loop pump was on but the heat pump was off and heating was provided by steam HX.

(e) There are some periods when the building hot water loop return temperature was higher than $124^{\circ} \mathrm{F}$ and no water flow in the ground loop was observed.

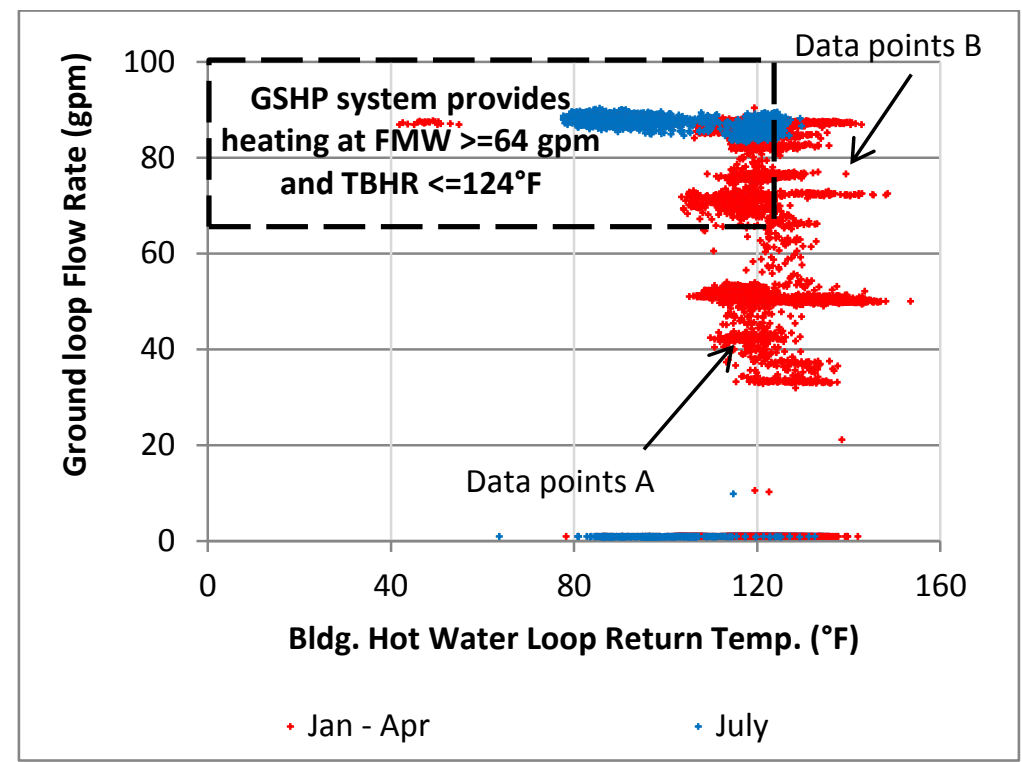

Fig. 19. Ground loop flow rate versus building hot water loop return temperature.

Table 2 summarizes the conditions of operation of the heat pump based on the observations from the measured data.

Table 2. Operation of heat pump

\begin{tabular}{|l|l|l|}
\hline \multicolumn{1}{|c|}{ Ground loop flow (FMW) } & \multicolumn{1}{|c|}{$\begin{array}{c}\text { Hot water return temperature } \\
\text { (TBHR) } \leq \mathbf{1 2 4}^{\circ} \mathbf{F}\end{array}$} & $\begin{array}{c}\text { Hot water return temperature } \\
(\mathbf{T B H R}) \mathbf{1 2 4}^{\circ} \mathbf{F}\end{array}$ \\
\cline { 1 - 2 }$\geq 64 \mathrm{gpm}$ (pump on) & $\begin{array}{l}\text { Heat Pump on } \\
\text { (heat pump was off occasionally) }\end{array}$ & Heat pump off: steam HX alone \\
\hline$>0,<64$ gpm (pump on) & Heat pump off: steam HX & Heat pump off: steam HX alone \\
\hline 0 (pump off) & Heat pump off: steam HX alone \\
\hline
\end{tabular}



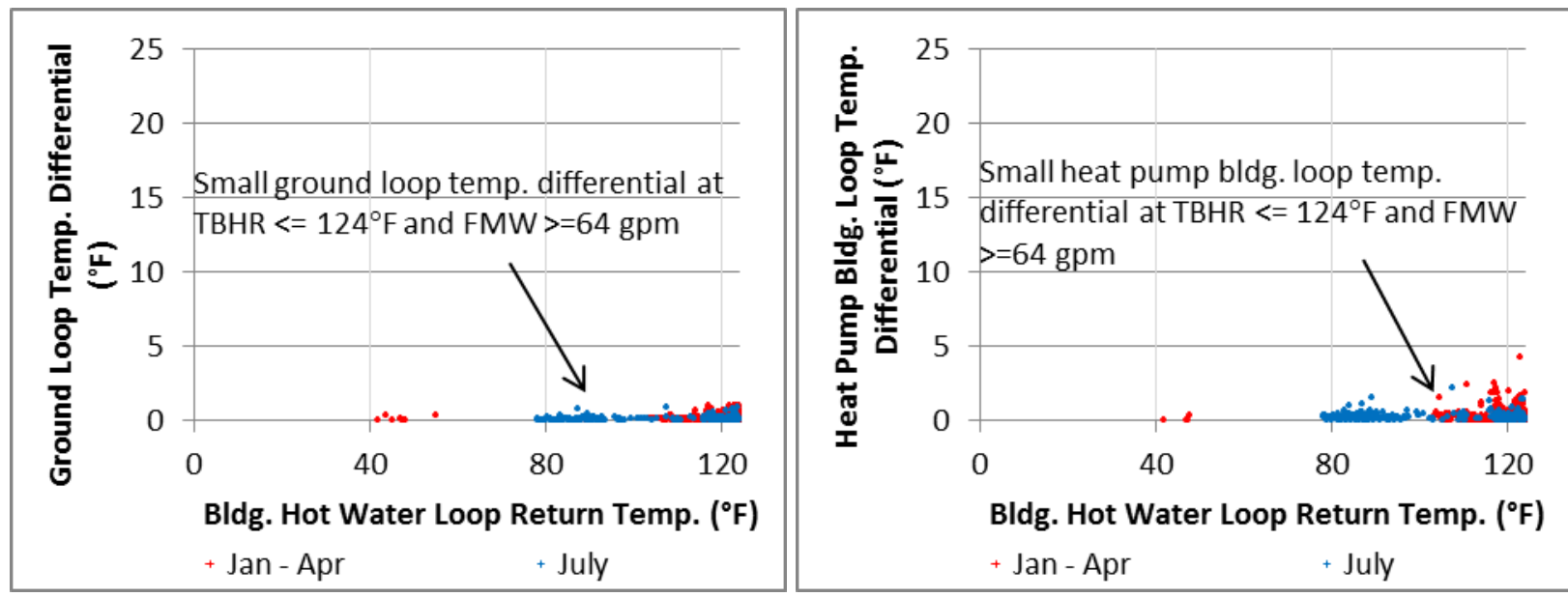

Fig. 20. Temperature differential in (left) ground loop and (right) heat pump building loop versus building hot water loop return temperature.

Therefore, for further analysis, the system performance in the heating mode is determined from the January-April measured data with the following periods excluded from the analysis when the GSHP system was not operating. System performance in the cooling mode is determined from the measured data in July.

(a) Ground loop flow rate of 64 gpm or above

(b) Temperature differential in the ground loop and heat pump load-side loop of $1^{\circ} \mathrm{F}$ or above

(c) Building hot water loop return temperature of $124^{\circ} \mathrm{F}$ or below

(d) Outdoor air temperature below $60^{\circ} \mathrm{F}$ (but above $10^{\circ} \mathrm{F}$ to allow heat pump operation)

\subsection{Heat Transfer}

\subsubsection{Heat Transfer in Ground Loop}

Heat transfer through the ground loop was calculated by using the ground loop flow rate and difference between the ground loop supply and return water temperatures:

$$
Q G L=\frac{k * F M W *(T M W S-T M W R)}{1000}
$$

where

$Q G L=$ heat transfer to mine water $(\mathrm{kBtu} / \mathrm{h})($ extraction $>0$, rejection $<0)$,

$F M W=$ mine water loop flow rate (GPM),

$T M W S=$ mine water supply temperature to heat pump $\left({ }^{\circ} \mathrm{F}\right)$,

$T M W R=$ mine water return temperature to heat pump $\left({ }^{\circ} \mathrm{F}\right)$,

$k$ is a factor that incorporates conversion factors and the specific gravity of the fluid, which is estimated to be $480 \mathrm{Btu} / \mathrm{h}-\mathrm{gpm}-{ }^{\circ} \mathrm{F}$ for $20 \%$ ethanol at $60^{\circ} \mathrm{F}$.

Figure 21 shows the hourly heat transfer rate from January through July. The heat extraction during heating operation is shown as positive, and the heat rejection during cooling operation is shown as negative. The brief areas of heat rejection in the winter are thought to be due to transients at startup and shutdown of a heat pump operation cycle. The data showing heat extraction in July are the times during the cold nights or when reheat was required.

The heat extraction rate through the ground loop averaged $367 \mathrm{kBtu} / \mathrm{h}$ during heat pump operation during January-April, with brief periods reaching a maximum of $697 \mathrm{kBtu} / \mathrm{h}$. The heat rejected during July 
averaged $500 \mathrm{kBtu} / \mathrm{h}$ and reached a maximum of $1,022 \mathrm{kBtu} / \mathrm{h}$. The total heat extraction during JanuaryApril amounted to 341 MMBtu. This includes the intermittent operation of the GSHP system during January-March. The heat rejection in July amounted to 253 MMBtu.

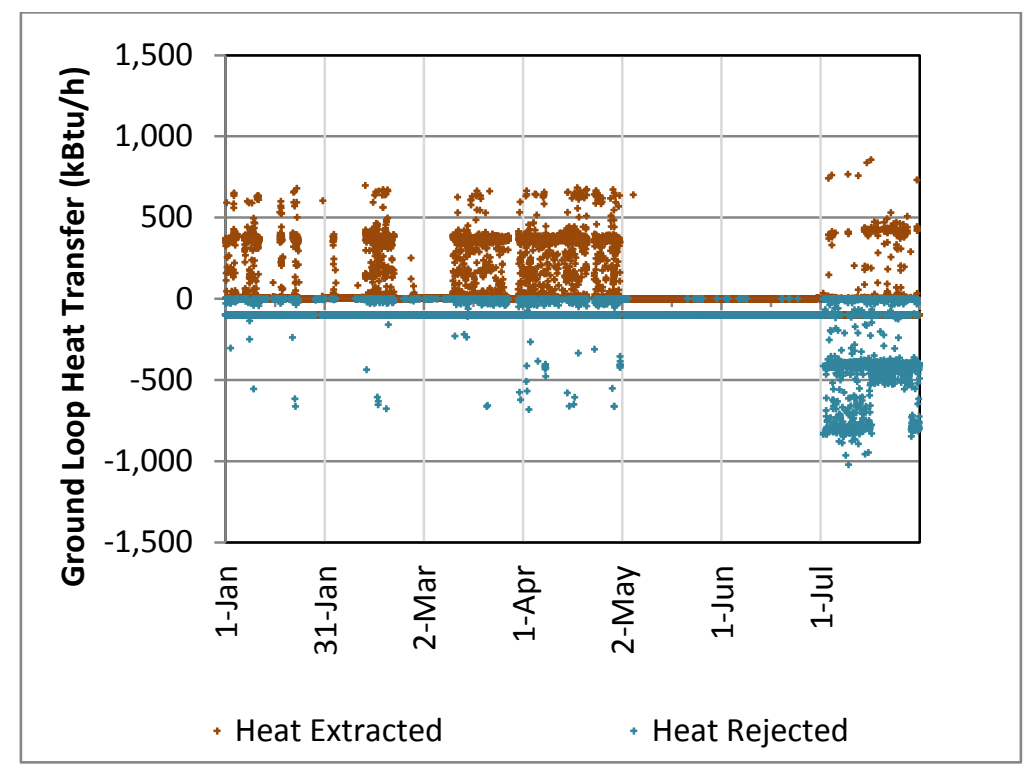

Fig. 21. Ground loop heat transfer rate.

\subsubsection{Heat Transfer in Heat Pump Load-Side Loop}

The heat-pump load-side water flow rate was not measured. Therefore, heat transfer by the heat pump was roughly estimated at this point ${ }^{4}$ using a constant flow rate and temperature difference between the heat pump load-side supply and return water temperatures:

$$
Q H P=\frac{k * F H P *(T H P S-T H P R)}{1000}
$$

where

$Q H P \quad=$ heat transfer to heat pump load-side loop $(\mathrm{kBtu} / \mathrm{h})$ (heating $>0$, cooling $<0)$,

FHP = heat pump load-side loop flow rate (GPM),

THPS = heat pump supply water temperature $\left({ }^{\circ} \mathrm{F}\right)$,

$T H P R=$ heat pump return water temperature $\left({ }^{\circ} \mathrm{F}\right)$,

$k$ is a factor that incorporates conversion factors and the specific gravity of the fluid, which is 500

$\mathrm{Btu} / \mathrm{h}-\mathrm{gpm}-{ }^{\circ} \mathrm{F}$ for water.

Assuming a constant flow rate of $80.9 \mathrm{gpm}$, which is estimated according to the load-side loop circuit setter setting, the heat pump delivered heating and cooling are plotted in Fig. 22. On average, the heat pump delivered $402 \mathrm{kBtu} / \mathrm{h}$ (peaking at $995 \mathrm{kBtu} / \mathrm{h}$ ) during January-July and $518 \mathrm{kBtu} / \mathrm{h}$ (peaking at $1,266 \mathrm{kBtu} / \mathrm{h}$ ) in July. ${ }^{5}$ In July, the heat pump extracted $150 \mathrm{kBtu} / \mathrm{h}$ on average (peaking at $303 \mathrm{kBtu} / \mathrm{h}$ ). This amounted to an average of 3.46 MMBtu/day (8.76 MMBtu/day at maximum) heating provided during January-April and an average of 2.53 MMBtu/day (3.58 MMBtu/day at maximum) cooling provided in July.

\footnotetext{
${ }^{4}$ The heat transfer by heat pump was calculated more accurately in the next section using the heat pump source-side heat transfer and operating efficiency of the heat pump

${ }^{5}$ The heat pump provided heating in July when the outdoor air temperature dropped below $60^{\circ} \mathrm{F}$ at night.
} 


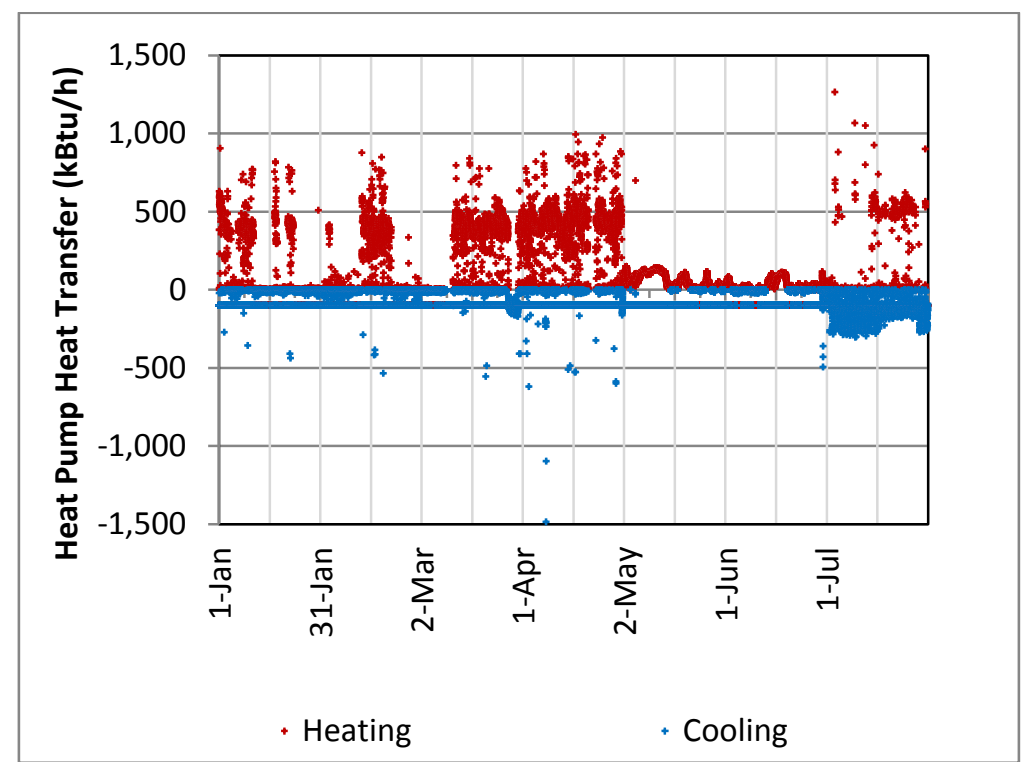

Fig. 22. Heat pump delivered energy (flow rate * deltaT, assuming constant flow rate).

\subsubsection{Heat Transfer in Building Hot Water Loop}

Heat transfer through the building hot water loop was calculated by using the hot water flow rate and the temperature difference between the supply and return water temperatures of the building loop:

$$
Q B H=\frac{k * F B H *(T B H S-T B H R)}{1000}
$$

where

$Q B H=$ heat transfer to the building $(\mathrm{kBtu} / \mathrm{h})$ (heating $>0)$,

$F B H=$ building heating loop water flow rate (GPM),

$T B H S=$ building heating loop supply water temperature $\left({ }^{\circ} \mathrm{F}\right)$,

$T B H R=$ building heating loop return water temperature $\left({ }^{\circ} \mathrm{F}\right)$,

$k$ is a factor that incorporates conversion factors and the specific gravity of the fluid, which is $500 \mathrm{Btu} / \mathrm{h}-\mathrm{gpm}-{ }^{\circ} \mathrm{F}$ for water. 


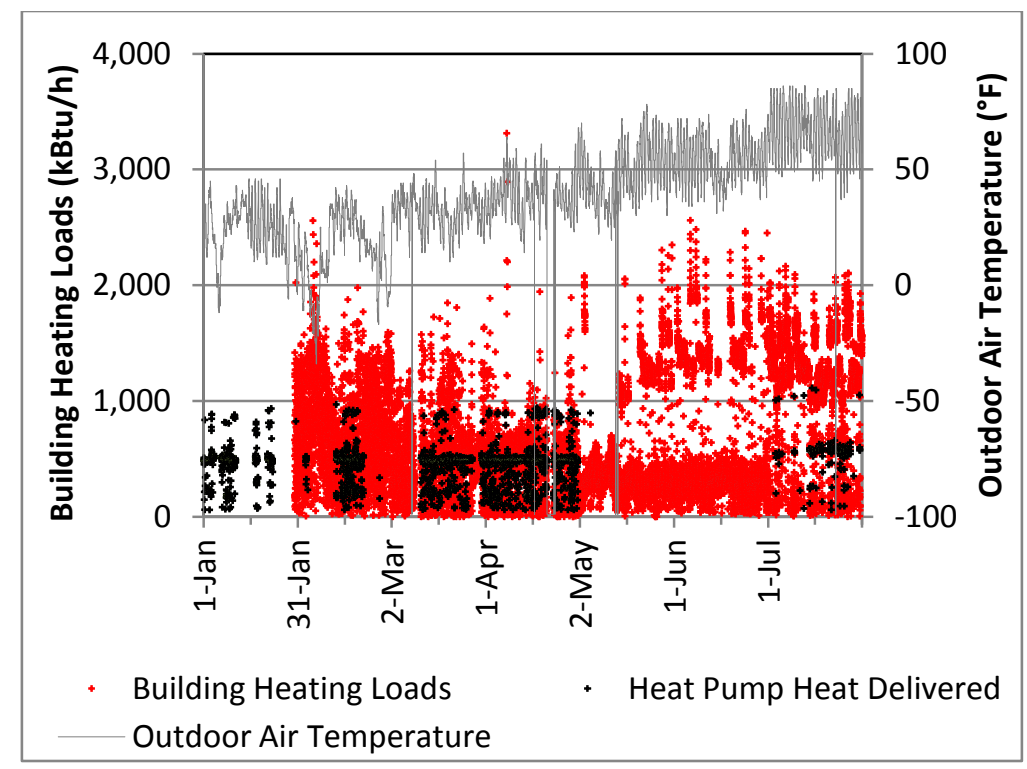

Fig. 23. Building heating loads.

The calculated heat transfer rate of the building hot water loop and the coincidental ambient temperatures are plotted in Fig. 23. In this figure, heating delivered by the heat pump is also plotted for comparison with the building heating loads. It is interesting to note when the building heating loads were large during the winter, the heat pump did not run much because the higher return water temperature from the building hot water loop exceeded the heat pump operating temperature.

\subsection{GSHP System Efficiency}

The overall efficiency of the GSHP system is determined with the approach shown in Fig. 24. From the measured water temperature and flow rate in the ground loop, heat extracted from (or rejected to) the ground loop was calculated as in Section 2.3.1. The operating efficiency of the heat pump is determined from the manufacturer's performance data with the measured source-side leaving water temperature and load-side leaving hot/chilled water temperature. Then, heat pump power consumption in the heating (or cooling) mode is calculated from the heat extraction from (or rejection to) the ground loop divided by the heat pump efficiency. Then, heating (or cooling) delivered to the building is calculated from the heat extracted from (or rejection to) the ground and the calculated heat pump energy use. Finally, the overall GSHP system efficiency is calculated as the ratio of the total heat delivered (and extracted) to the sum of the heat pump power consumption and the estimated ground loop pumping power consumption. Ground loop pump power was estimated by assuming a constant power draw of $4.476 \mathrm{~kW}$ for the $7.5 \mathrm{hp}$ constant speed pump. 


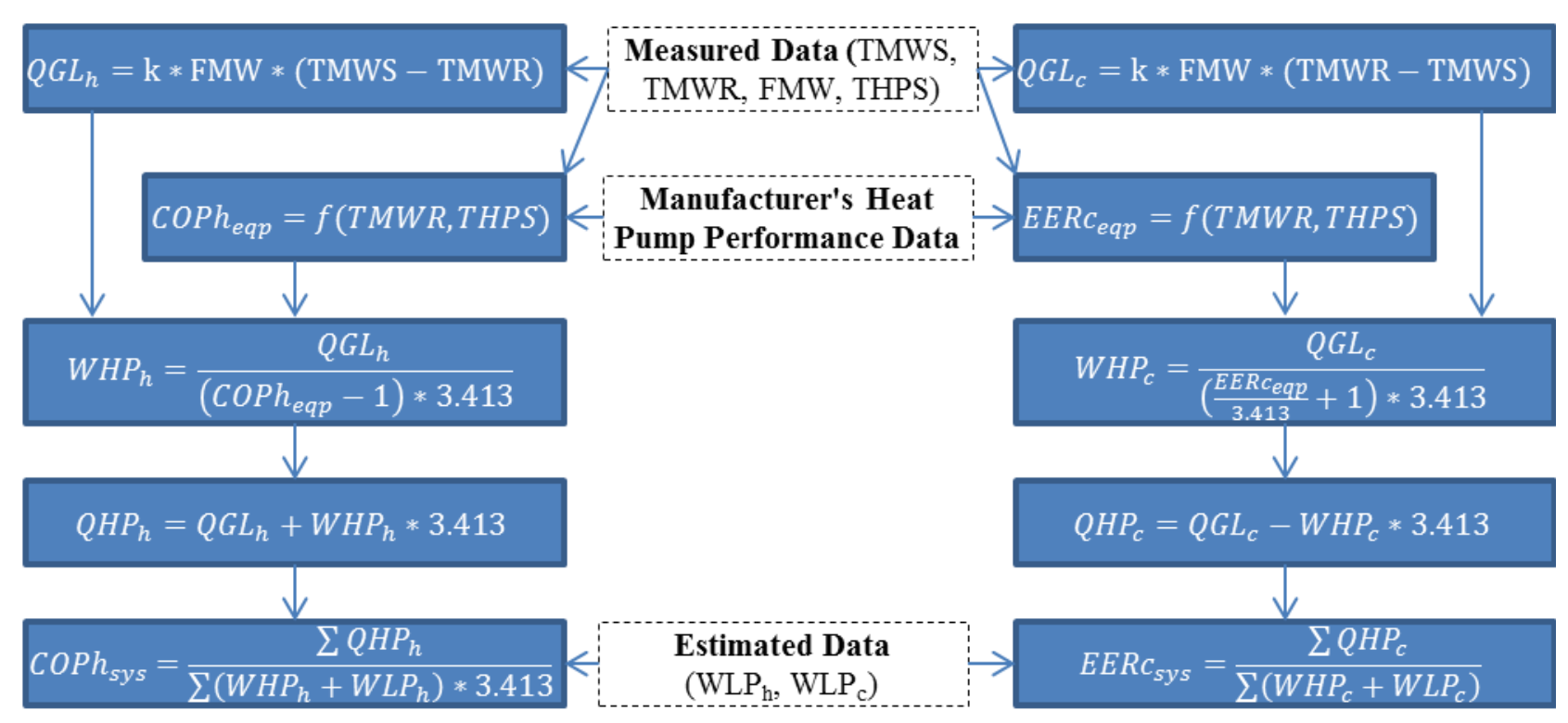

Fig. 24. Determining GSHP system efficiency.

\subsubsection{Operating Efficiency of Heat Pump Equipment}

The efficiency of the heat pump, indicated by the coefficient of performance (COP) for heating and the energy efficiency rating (EER) for cooling, were determined from the curve-fit of the manufacturer's performance data (Multistack 2014) available for varying leaving source water and leaving hot/chilled water temperature. The manufacturer's performance data in the heating and cooling modes are plotted in Fig. 25.These can be expressed as a second-order polynomial of the following form, with the coefficients for the heating and cooling modes shown in Table 3.

Table 3. Coefficients for the heat pump performance curve-fit

\begin{tabular}{|c|c|c|}
\hline Coefficient & COPh & EERc \\
\hline C 0 & 8.24 & 24.94 \\
\hline C 1 & 0.1182 & -0.2924 \\
\hline C2 & -0.08303 & 0.4545 \\
\hline C 3 & 0.00054 & 0.00098 \\
\hline C 4 & -0.0009 & -0.00321 \\
\hline C5 & 0.00028 & 0.00149 \\
\hline
\end{tabular}

Ef ficiency (Heating COP or Cooling EER) $=f\left(T_{1}, T_{2}\right)$

$$
=C_{0}+C_{1} T_{1}+C_{2} T_{2}+C_{3} T_{1}^{2}+C_{4} T_{1} T_{2}+C_{5} T_{2}{ }^{2},
$$

where

$T_{1}=$ leaving source-side water temperature (TMWR),

$T_{2}=$ leaving load-side water temperature (THPS). 

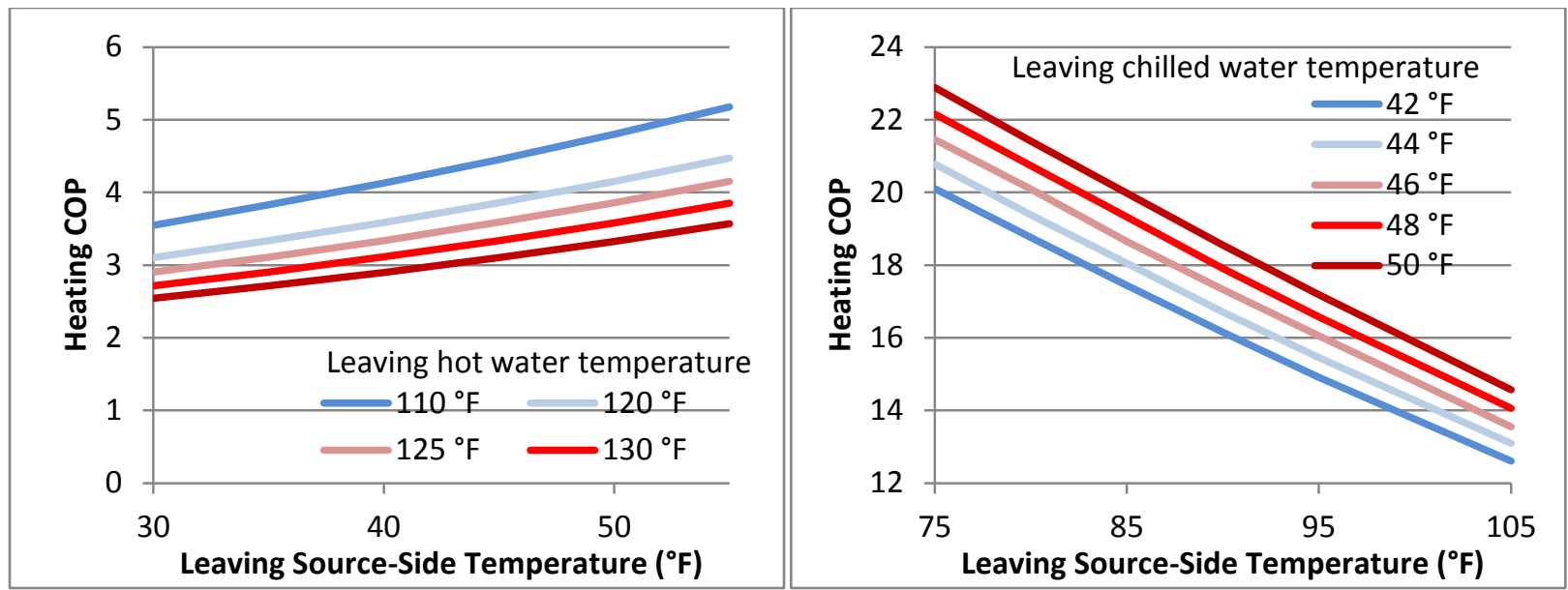

Fig. 25. Heat pump efficiency curves.

As shown in Fig. 26, of note is that the measured leaving source-side and leaving hot/chilled water temperature exceeded the temperature range for which the manufacturer's performance data was available. In the heating mode, the measured temperature of leaving source-side water was usually warmer than the maximum of the rated temperature range (i.e., $30-55^{\circ} \mathrm{F}$ ). Therefore, the heat pump is expected to operate at higher efficiency in the heating mode. However, for this analysis, conservative estimates of the heat pump heating COP were made by limiting the maximum leaving source-side temperature to $55^{\circ} \mathrm{F}$.

In the cooling mode, the measured temperature of leaving source-side water in some time periods during July was warmer than the maximum of the rated temperature range (i.e., $75-105^{\circ} \mathrm{F}$ ) (see data points A). During these periods, the heat pump is expected to operate at lower efficiency. However, for this analysis, the heat pump cooling EER estimation was made by limiting the maximum leaving source-side temperature to $100^{\circ} \mathrm{F}$. The measured temperature of leaving chilled water in some afternoons during late July was warmer than the rated temperature range (i.e., $42-50^{\circ} \mathrm{F}$ ) (see data points B). During these periods, the heat pump is expected to operate at higher efficiency. However, for this analysis, conservative estimates of the heat pump cooling EER were made by limiting the maximum leaving loadside (chilled water) temperature to $50^{\circ} \mathrm{F}$. Also, the maximum leaving source-side temperature was limited to $105^{\circ} \mathrm{F}$. 

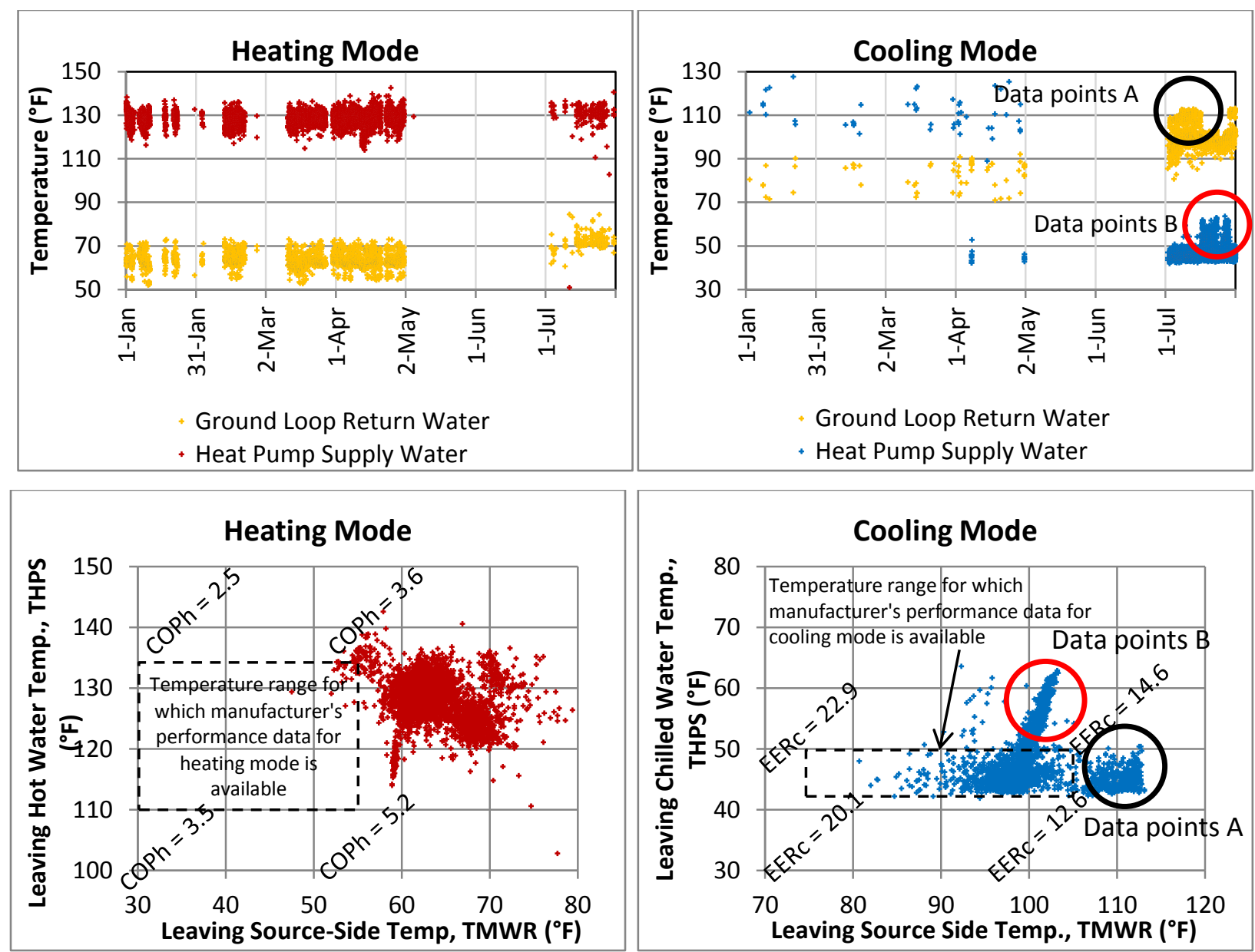

Fig. 26. Measured heat pump leaving source-side and leaving load-side water temperature.

The operating efficiency of the heat pump in the heating and cooling modes is plotted in Fig. 27. Figure 27(a) shows the heating COP of the heat pump, which ranged between 3.2 and 4.7. Figure 27(b) shows the cooling EER of the heat pump, which ranged between 12.7 and 19.5. Figure 27(c) and (d) show the heating COP and cooling EER against OA temperatures. No temperature dependence was observed for the heating mode, because the supply hot water temperature and the ground loop return temperature were not related to outdoor air temperature. ${ }^{6}$ On the other hand, an increasing trend of the cooling EER with increased OA temperatures was observed because the ground loop temperature was found to increase with increased OA temperatures. Data points A marked in Fig. 27(b) and (d) correspond to data points A marked in Fig. 26, when the measured temperature of leaving source-side water was warmer than the maximum of the rated temperature range (i.e., $75-105^{\circ} \mathrm{F}$ ), which resulted in the heat pump operation at lower cooling efficiency.

Aggregating the heat delivered and power consumed by the heat pump, the average heating COP of the heat pump was 3.95 during January-April and the average cooling EER was 15.3 in July.

\footnotetext{
${ }^{6}$ An OA reset schedule could have been used to adjust the supply water temperature of the heat pump for increased efficiency. See Section 3.1.2 for a proposed schedule for heat pump operation.
} 


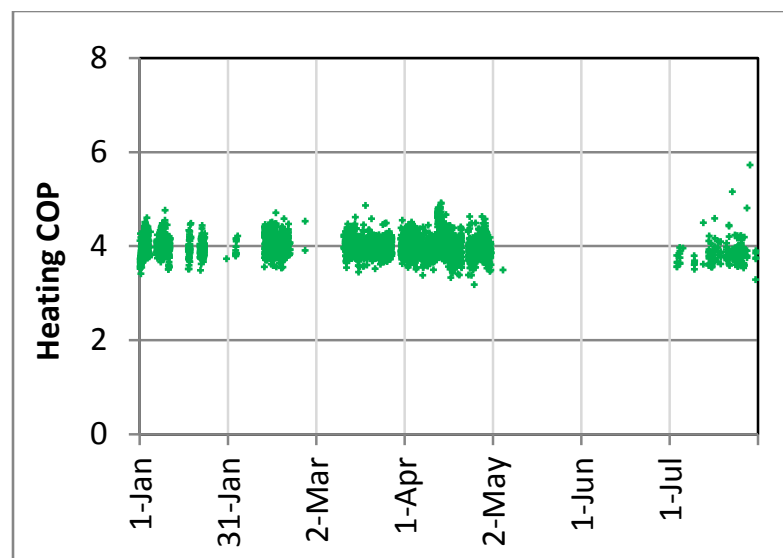

(a)

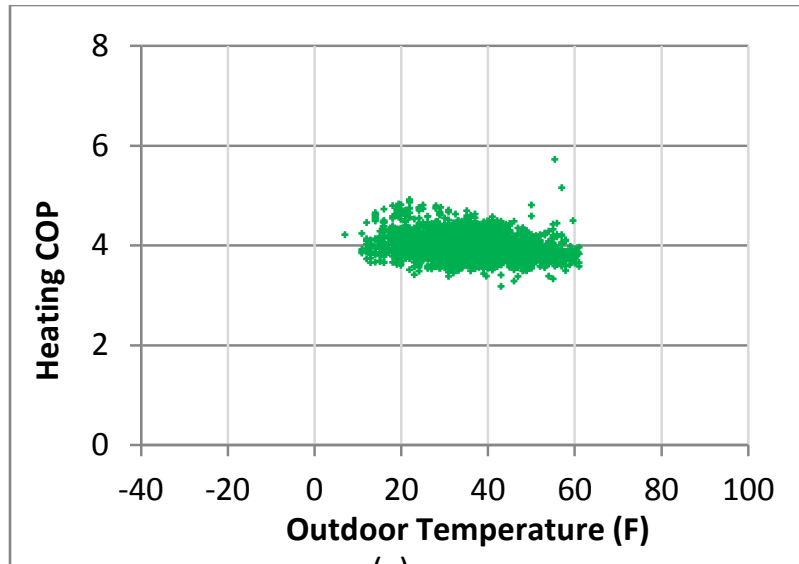

(c)

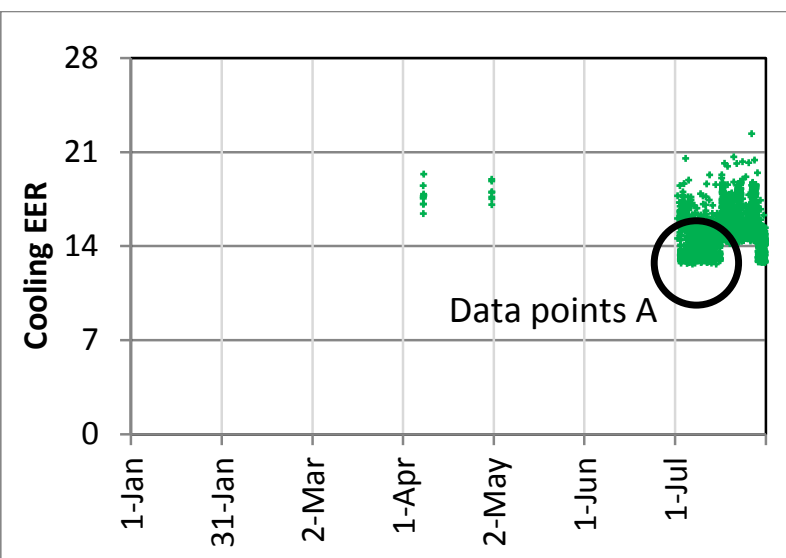

(b)

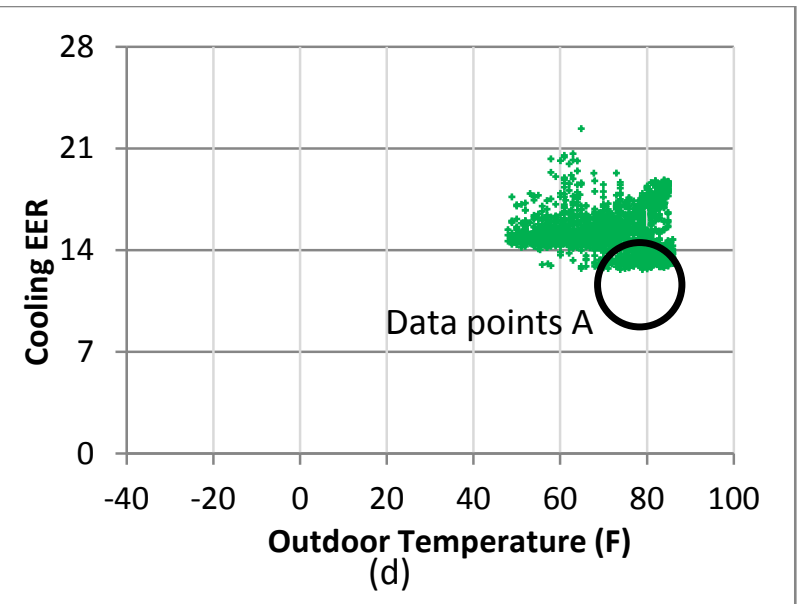

(d)

Fig. 27. Heat pump equipment efficiency.

\subsubsection{Heat Pump Power Consumption}

The heat pump power consumption is calculated by using the heat extracted and dumped in the ground loop and the efficiency of the heat pump equipment. Figure 28 shows the time series plot and monthly total of the heat pump power consumption. During most of the measurement period, the heat pump power draw is around $40 \mathrm{~kW}$ in the heating mode with a peak of about $75 \mathrm{~kW}$; the power draw in the cooling mode is around $20 \mathrm{~kW}$ with a peak of about $55 \mathrm{~kW}$. During continuous operation of the heat pump in April and July, the total monthly power consumption was between 14,000 and 15,000 kWh. 

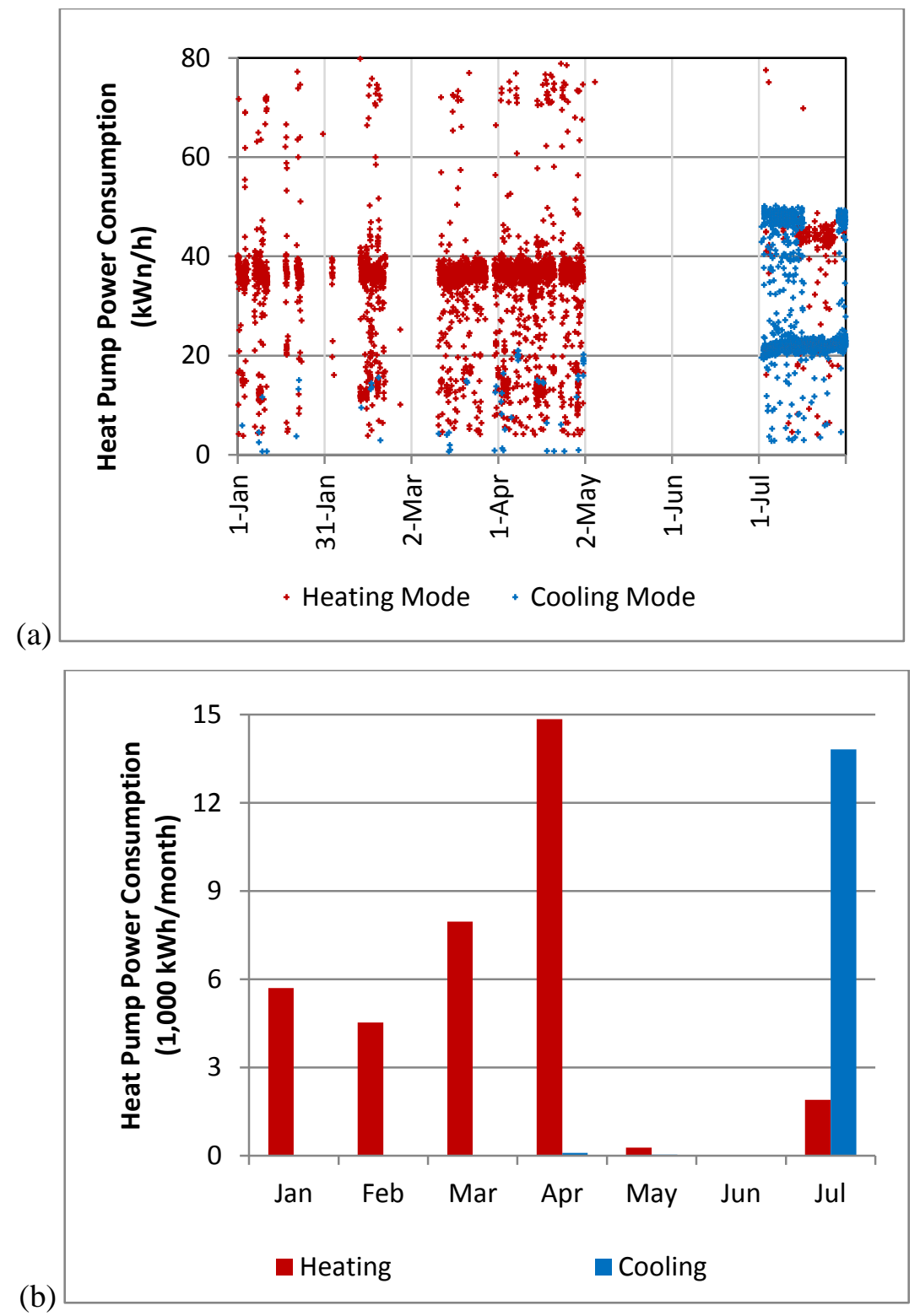

Fig. 28. Heat pump power consumption.

\subsubsection{Heat Delivered by Heat Pump}

The heat delivered by the heat pump is calculated as the sum of heat extracted from the ground loop and the power input by the heat pump. Figure 29 shows the time series plot and monthly total of the heating delivered by the heat pump. During most of the measurement period, the heating provided by the heat pump was around $500 \mathrm{kBtu} / \mathrm{h}$ with a peak of about $950 \mathrm{kBtu} / \mathrm{h}$. The cooling provided by the heat pump was calculated by subtracting the power input of the heat pump from the heat rejected to the ground loop. It is in the $230-450 \mathrm{kBtu} / \mathrm{h}$ range during most of the measurement period with a peak of about $730 \mathrm{kBtu} / \mathrm{h}$. During January-April, the heat pump provided 445 MMBtu heating to the building. In July, 204 MMBtu cooling was provided by the heat pump. The few instances of cooling provided in winter (as shown in Fig. 29) is thought to be due to noise in the measured data during the transient periods at the beginning and end of heat pump operation cycles. 

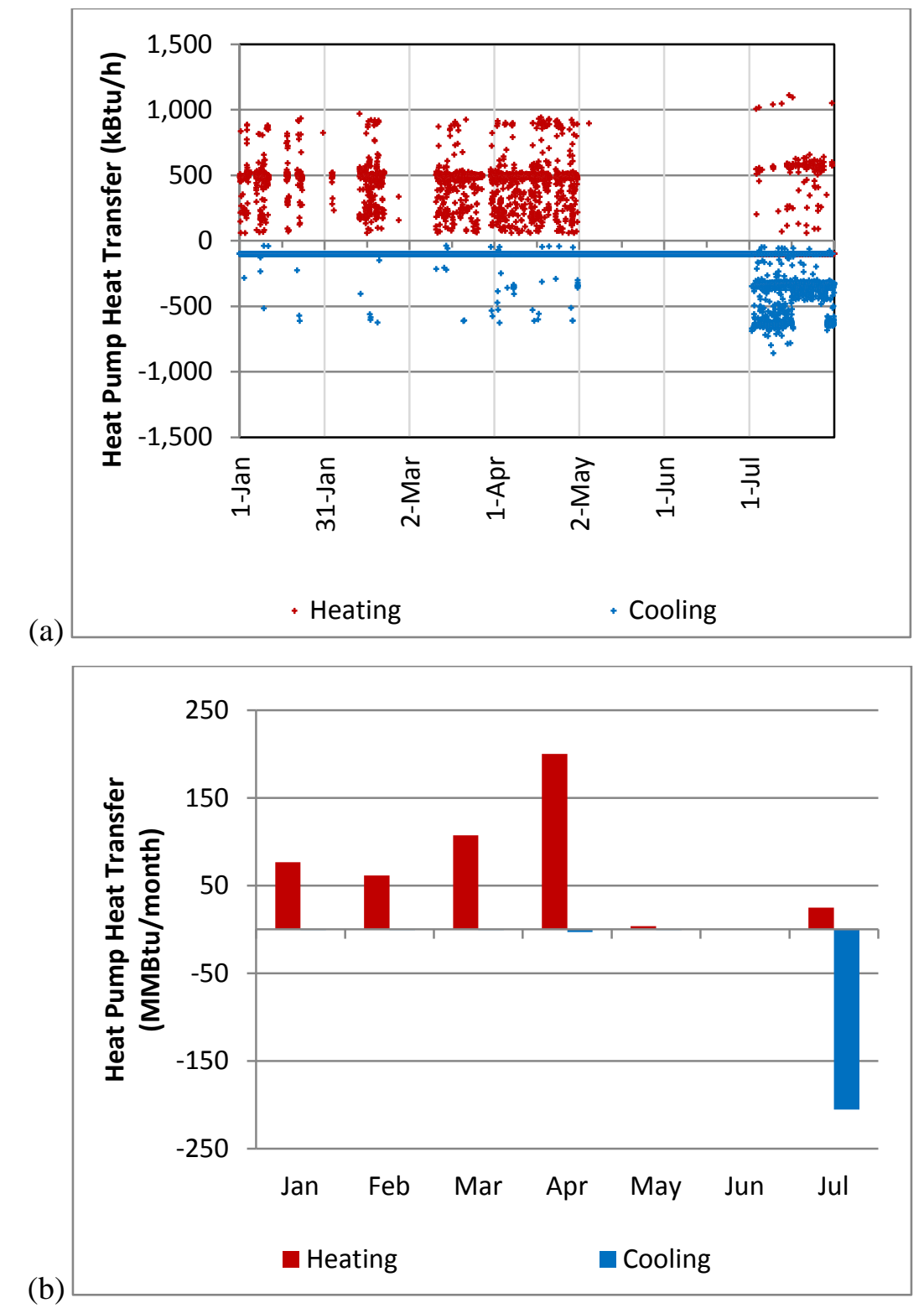

Fig. 29. Heat pump delivered heating and cooling.

\subsubsection{Pumping Power Consumption}

The water in the ground loop is circulated by two redundant $7.5 \mathrm{hp}$ constant speed TACO pumps. Only the flow rate in the ground loop was measured; pump power was not measured. Therefore, a constant pumping power of $4.476 \mathrm{~kW}$ was assumed considering $80 \%$ average loading (i.e., $7.5 \mathrm{hp} \times 0.746 \mathrm{~kW} / \mathrm{hp}$ $\times 80 \%$ loading) for each data point when a flow of $64 \mathrm{gpm}$ or above ${ }^{7}$ in the ground loop was observed. With this assumption, the ground loop pump was estimated to consume 4,390 $\mathrm{kWh}$ when the GSHP system was operating in the heating mode during January-April, and 2,263 $\mathrm{kWh}$ in the cooling mode in July. Pumping performance is evaluated as the ratio of pump energy use relative to the total GSHP system energy use (referred as "pumping power fraction").

\footnotetext{
${ }^{7}$ This is to exclude periods with invalid data points at the beginning or the end of the operation of the pump.
} 
Figure 30 shows (a) a time series plot of the ground loop pumping power fraction, (b) a scatter plot of ground loop pumping energy use against the heat delivered by the heat pump, and (c) monthly aggregated power consumption of the heat pump and the pump, as well as the monthly average pumping power fraction. The pumping power fraction ranged between $8 \%$ and $60 \%$, higher at lower building loads. When aggregated by month, the average pumping fraction was $12 \%$ during January-April, after excluding the periods when the GSHP system was not operating on account of operating condition limitations or otherwise. In July the pumping power fraction in the cooling mode operation was 13\%. The pump power consumption is linearly related to the heating and cooling provided by the heat pump.

(a)
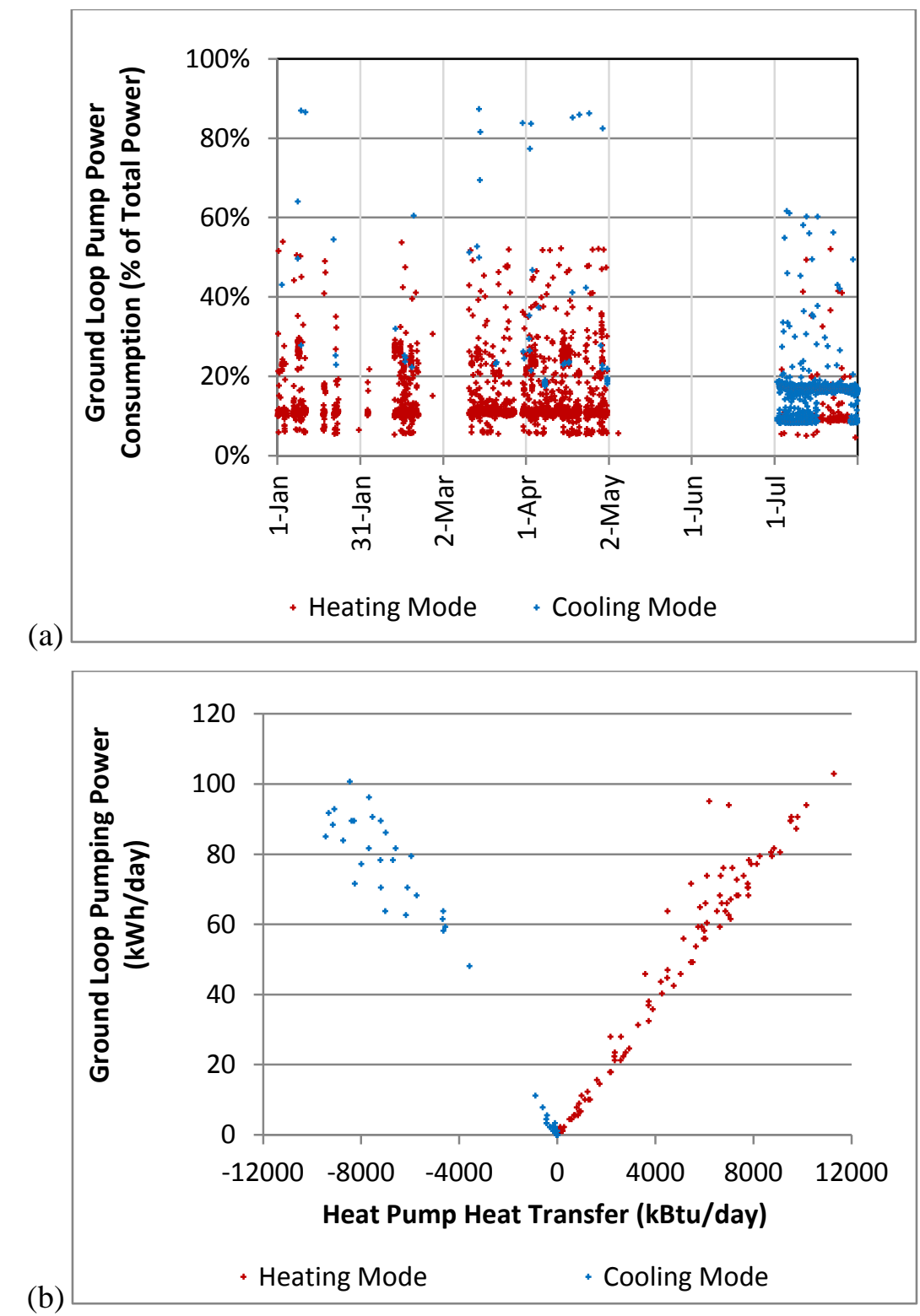


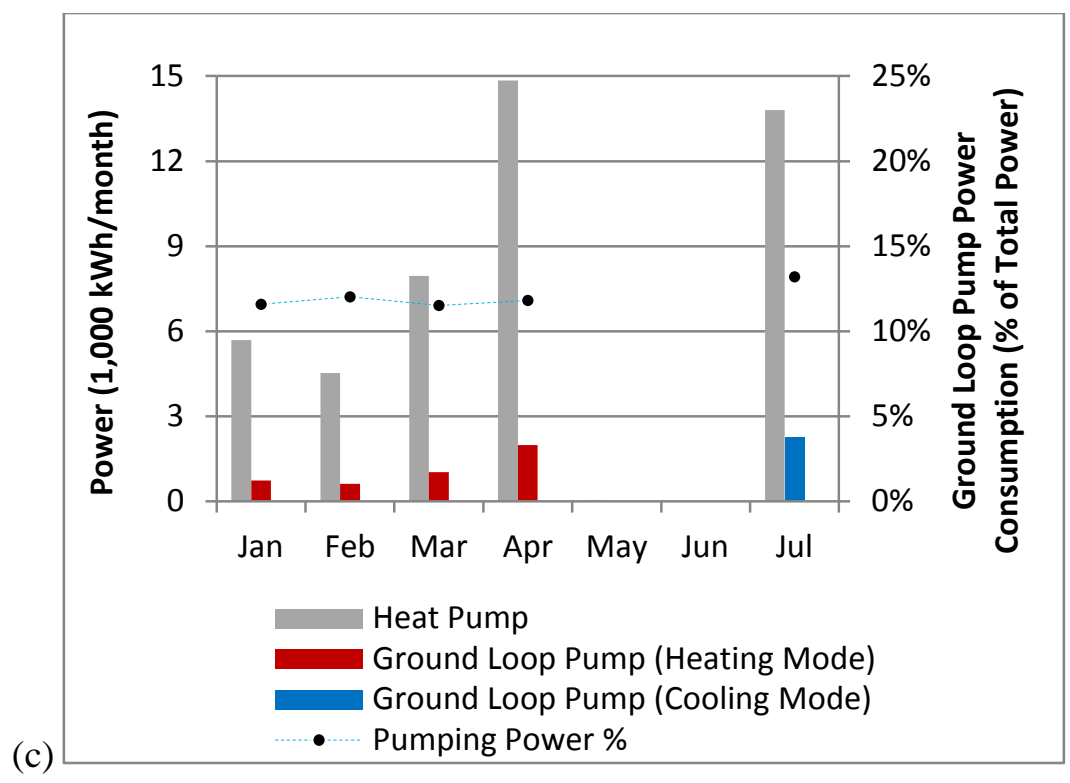

Fig. 30. Ground loop pumping power.

\subsubsection{Overall Efficiency of GSHP System}

The overall GSHP system efficiency is determined from the total heating or cooling provided by the heat pump and the sum of power consumptions of the heat pump and the ground loop circulation pump, as expressed in Eqs. (5) and (6).

$$
\begin{aligned}
& \mathrm{COP}_{\text {sys }}=\frac{\sum \mathrm{QHPH}}{\sum[\mathrm{WHPH}+\mathrm{WLPH}]} \\
& \mathrm{EER}_{\text {sys }}=\frac{\sum \mathrm{QHPC}}{\sum[\mathrm{WHPC}+\mathrm{WLPC}]}
\end{aligned}
$$

where $\mathrm{COP}_{\text {sys }}$ and $\mathrm{EER}_{\text {sys }}$ are the average COP and EER of the GSHP system, respectively, during the measurement period with valid data points (excluding the data when GSHP was not in operation); QHPH and QHPC are the heating and cooling provided by the heat pump, respectively; WHPH and WHPC are the power consumed by the heat pump, respectively; and WLPH and WLPC are the power consumption of the ground loop pump when the heat pump ran in the heating and cooling modes, respectively. The circulation of water flow in the load side of the heat pump is provided though the circulation pumps in the existing building hot and chilled water loops. The addition of the GSHP unit increased the head loss of the building hot and chilled water loops and the associated pumping power; however, this increased pumping power is not included in the above calculation since neither the pumping power nor the flow rate in the load side of the heat pump was measured. If the increased pumping power in the building hot and chilled water loops due to the heat pump operation is accounted for, the efficiency of the GSHP system will be 10-15\% lower (assuming load-side pumping power is the same as that of the ground loop pump).

Figure 31 shows the overall efficiency of the GSHP system compared with efficiency of the heat pump in both the heating and cooling modes. As expected, the GSHP system efficiency is lower than the heat pump efficiency because of the pumping energy use.

For the January-April measurement period, the heating COP of the GSHP system ranged between 3.0 and 4.3. Based on the measured data in July, the cooling EER of the GSHP system ranged between 11.8and 15.6. Aggregating the heat delivered and power consumed by the heat pump and ground loop pump, the 
heating COP of the GSHP system was 3.49 during January-April and the cooling EER of the GSHP system was 12.8 in July.
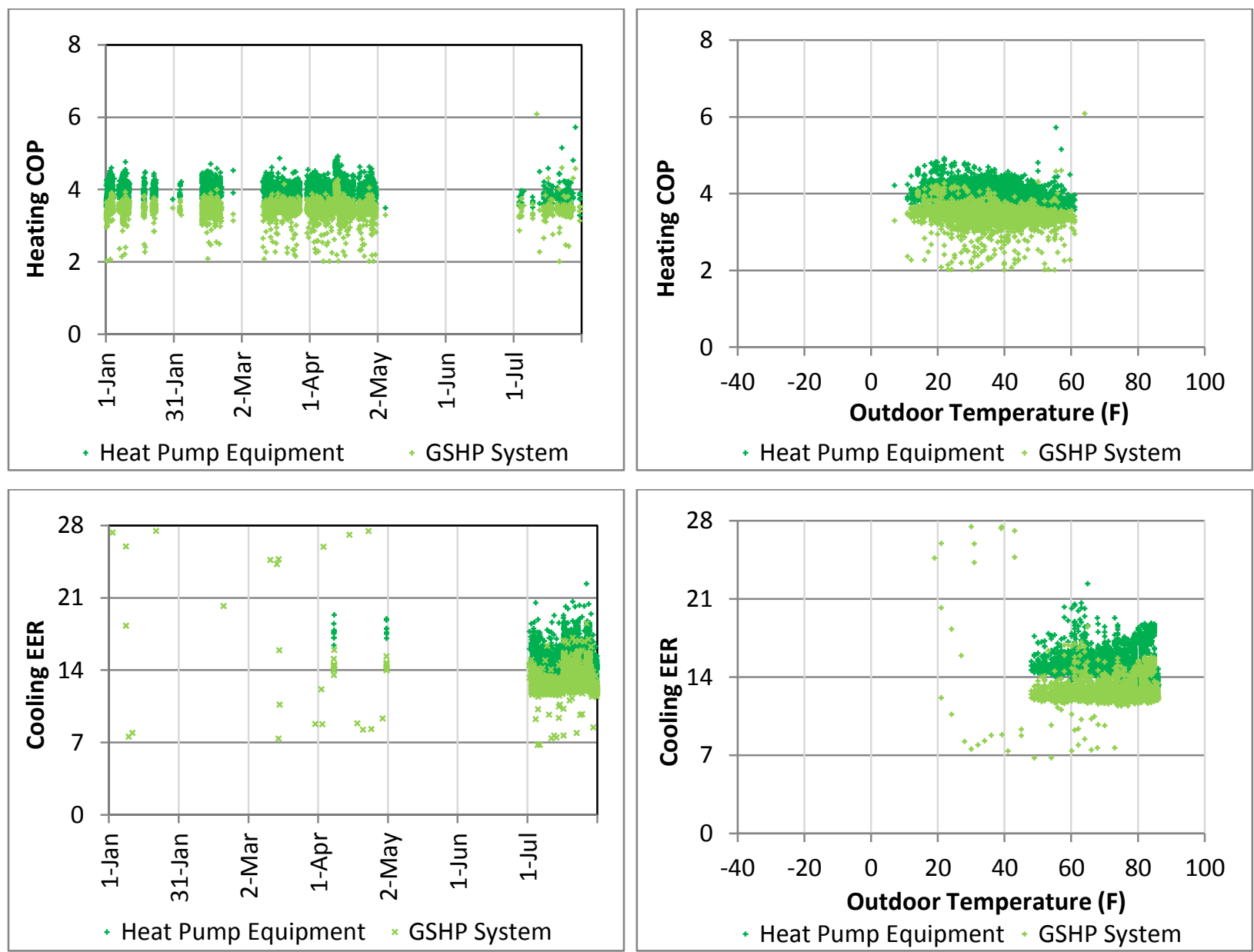

Fig. 31. GSHP system efficiency. 


\section{ANNUAL ENERGY ANALYSIS}

Annual energy analysis of the installed GSHP system was performed to (a) predict its full-year performance and (b) estimate the energy savings, operating cost savings, and emissions reduction benefits that could be achieved with respect to a baseline system.

The measured data available so far does not include building cooling loop measurement. Therefore, building cooling loads could not be predicted. Further, as seen in Fig. 32, the mine water temperature stays higher than the outdoor air temperature (measured or TMY3) in the winter and summer. In the summer, if mine water is used as a heat sink for the installed GSHP system operating in the cooling mode, it becomes even warmer. This suggests that using the GSHP system to provide cooling would be less efficient than using the existing air-cooled chiller. Therefore, the annual energy analysis performed was based on the premise that the GSHP system would provide only heating.

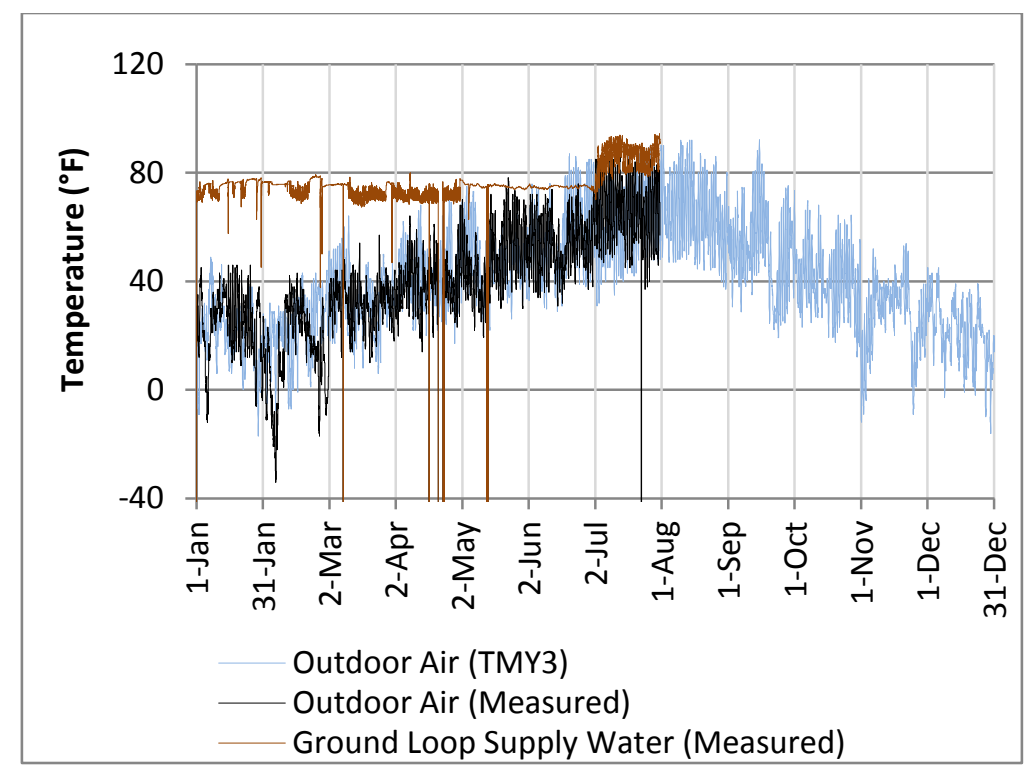

Fig. 32. Outdoor air temperature versus ground loop supply water temperature.

The maximum potential of the installed GSHP system would be achieved by operating the heat pump as long as there is any heating load, as initially planned. With this assumption, full-year energy analysis of the GSHP system is performed by using the heat balance equations and correlations derived from the measured data. The energy savings from the installed GSHP system are determined with respect to a baseline scenario in which the building heating loads are provided solely by the existing steam system. TMY3 weather data for Butte-Bert Mooney Airport, which is 6.5 miles southeast of the site, is used for the annual energy analysis.

\subsection{Prediction of Full-Year Performance of GSHP System}

Figure 33 shows the methodology to predict full-year GSHP system performance. First, the building heating loads $(\mathrm{QBH})$ were predicted as a function of OA temperature (TOA) based on a curve-fit derived from the January-April measured data. Assuming an OA temperature reset schedule for the heat pump supply temperature (THPS) and a constant mine water supply temperature (TMWS) as observed during the monitored time period, the heat pump heating capacity and heating COP were determined by using the heating performance data provided in the product data catalog (Multistack 2014). The heat pump heat 
output (QHPH) was calculated on the basis of the assumption that the heat pump operates to satisfy the building heating loads (QBH) until reaching its full capacity, and then the existing heating system will fill the gap between the building heating load and the heat pump capacity. The heat pump power consumption (WHPH) was calculated by using the heat pump heat output and heating COP.

The ground loop pump power consumption (WLP) was predicted from the pumping power ratio determined from the curve-fit for the daily ground loop pump energy use versus heat pump daily heat output (QHPH) derived from the January-April measured data. With the heat pump power consumption (WHPH) and pumping power consumption (WLP) calculated, the total power consumption of the GSHP system was calculated and the overall system COP was determined. These results of each of these steps are shown in the following sections.

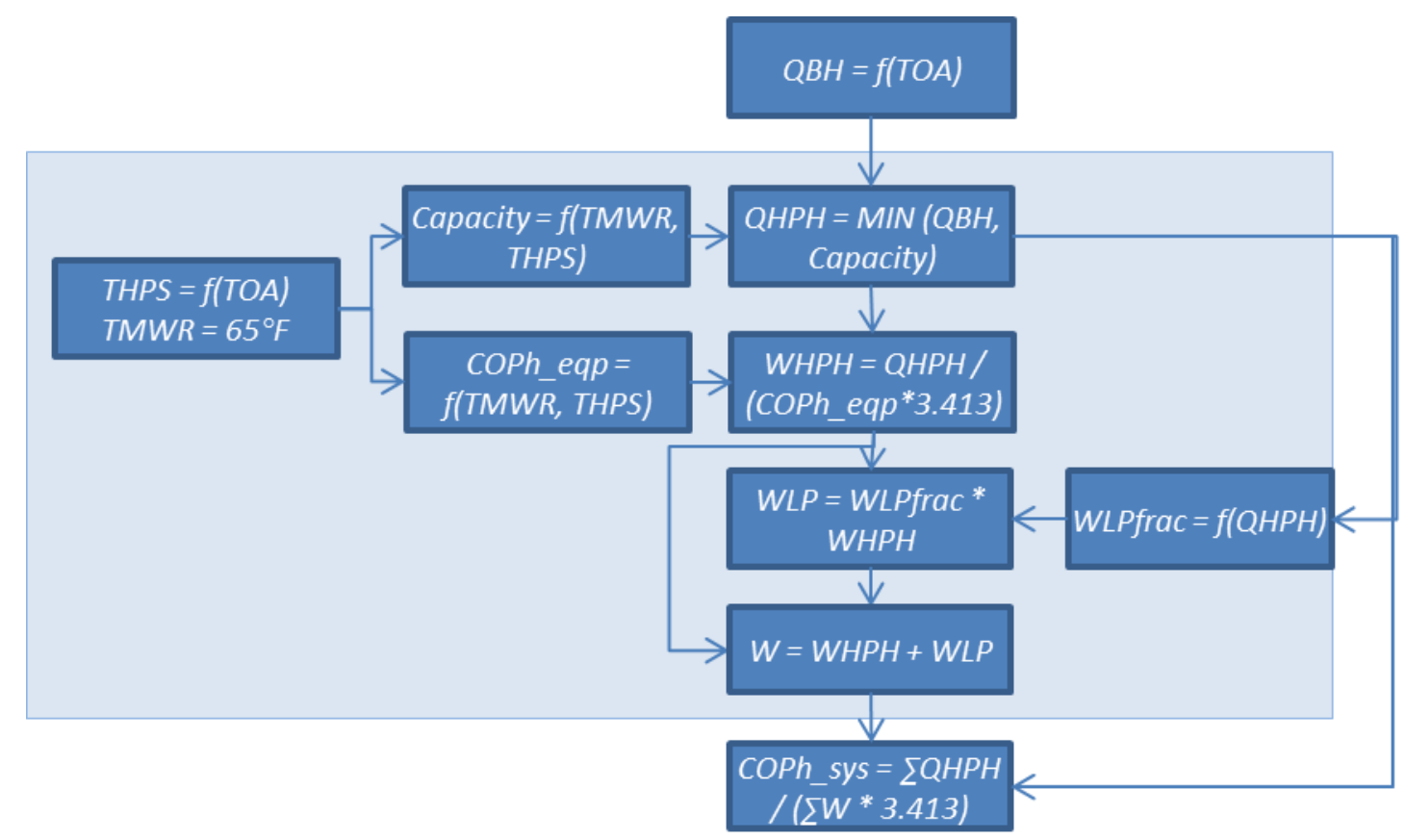

Fig. 33. Schematic of GSHP system performance prediction.

\subsubsection{Building Heating Loads}

Figure 34 shows a curve-fit between building heating loads and OA temperature based on the JanuaryApril measured data. Using this curve-fit combined with the assumption that heating is provided at OA temperatures below $60^{\circ} \mathrm{F}$, the building heating loads for the entire year are predicted. As shown in Fig. 35 (a), the peak heating loads in the winter exceed $1,000 \mathrm{kBtu} / \mathrm{h}$ a few times. In the summer, the temperature dropped below $60^{\circ} \mathrm{F}$ for a short period of time every day, during which $134-300 \mathrm{kBtu} / \mathrm{h}$ of heating loads are estimated. Figure 35 (b) shows the estimated monthly heating loads. The annual cumulative heating loads are 3,286 MMBtu/year. 


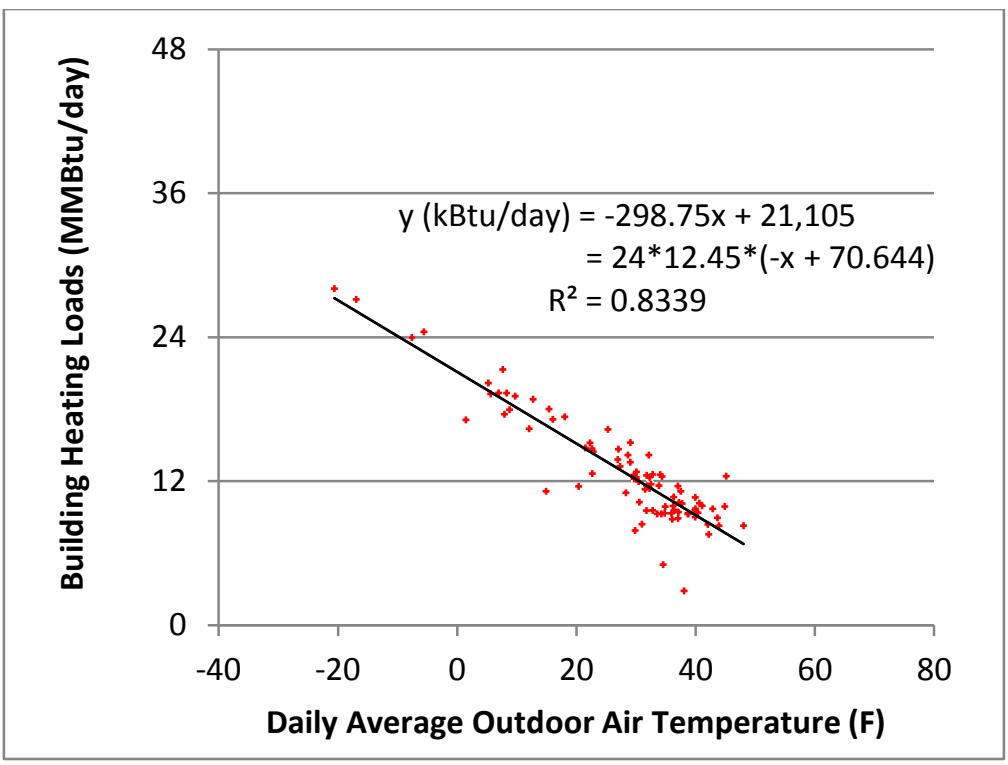

Fig. 34. Curve-fit for building heating loads as a function of outdoor air temperature.

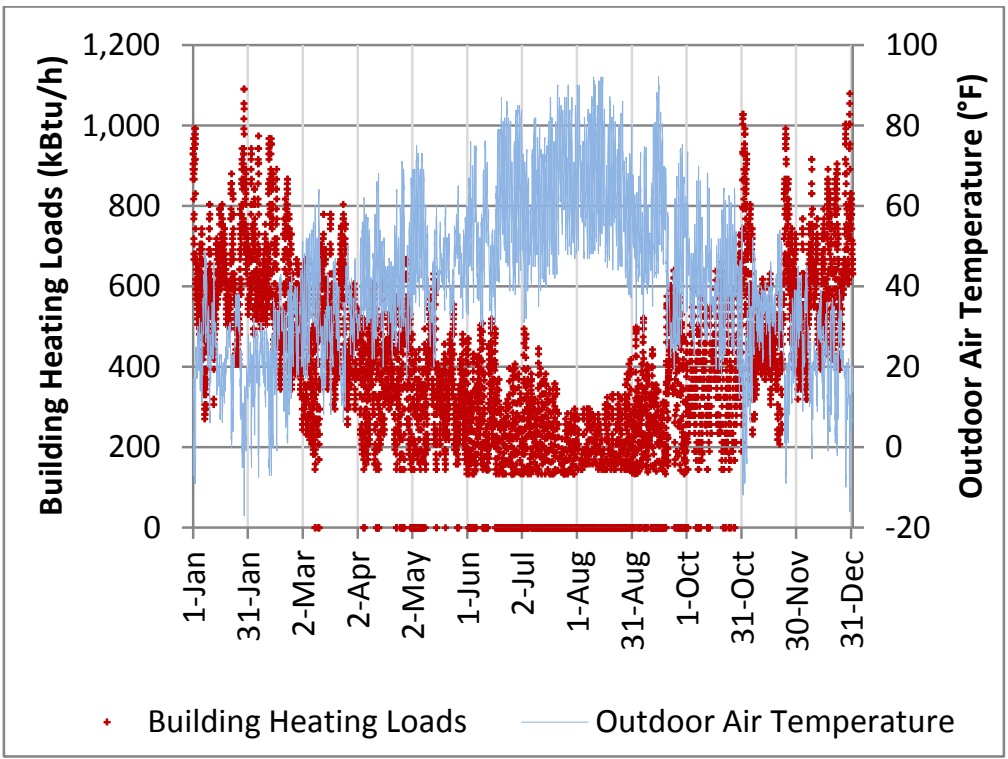

(a) 


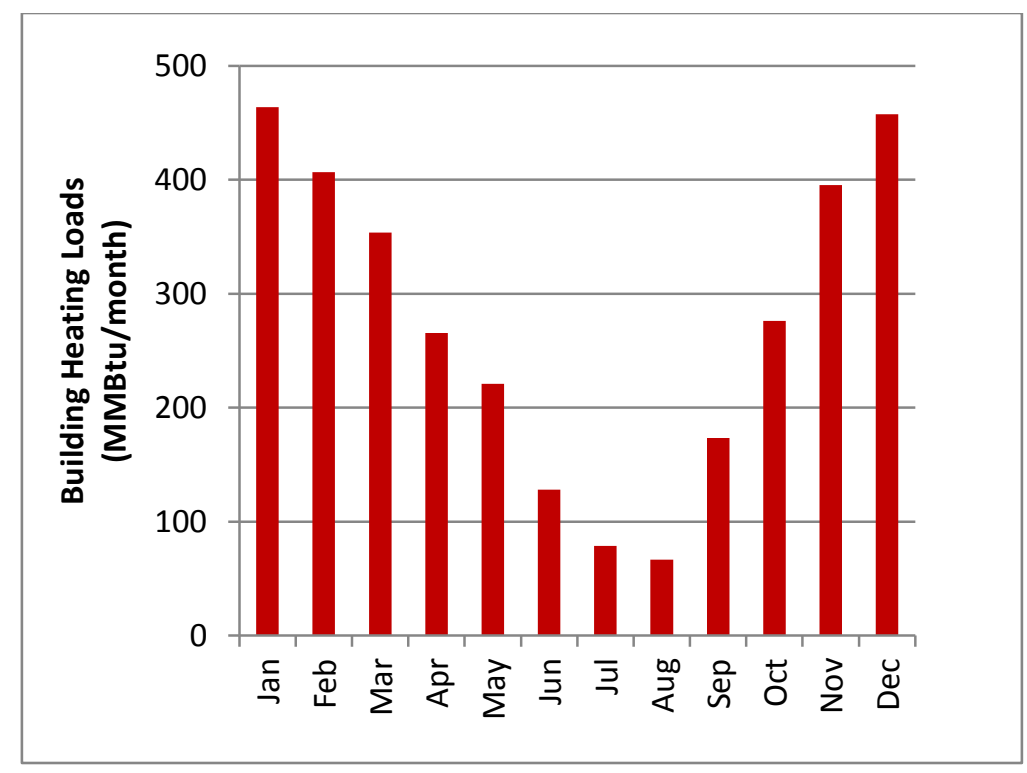

(b)

Fig. 35. Predicted building heating loads.

\subsubsection{Heat Pump Load-Side Supply Temperature}

According to the building operation and control specifications, an OA reset schedule governs the hot water temperature in the building hot water loop, to allow a return water temperature of $135^{\circ} \mathrm{F}$ at $-10^{\circ} \mathrm{F}$ $\mathrm{OA}$ temperature and $100^{\circ} \mathrm{F}$ at $60^{\circ} \mathrm{F} \mathrm{OA}$ temperature. Figure 36 shows the measured building hot water loop return temperature (light blue markers) compared with the OA reset schedule (black line), and shows that the hot water return temperature follows the reset schedule, except when the OA temperature is above $50^{\circ} \mathrm{F}$. At those times, the hot water return temperature is higher than what it would be reset according to the OA reset schedule. Figure 36 also shows the heat pump load-side supply and return temperatures. Clearly, the GSHP system was operated only at outdoor temperatures of $12^{\circ} \mathrm{F}$ or above, and the higherthan-scheduled hot water return temperature is due to the constant supply and return temperature of the heat pump. The heat pump supply temperature ranged between $120^{\circ} \mathrm{F}$ and $135^{\circ} \mathrm{F}$, providing a near constant TD of $10-15^{\circ} \mathrm{F}$. 


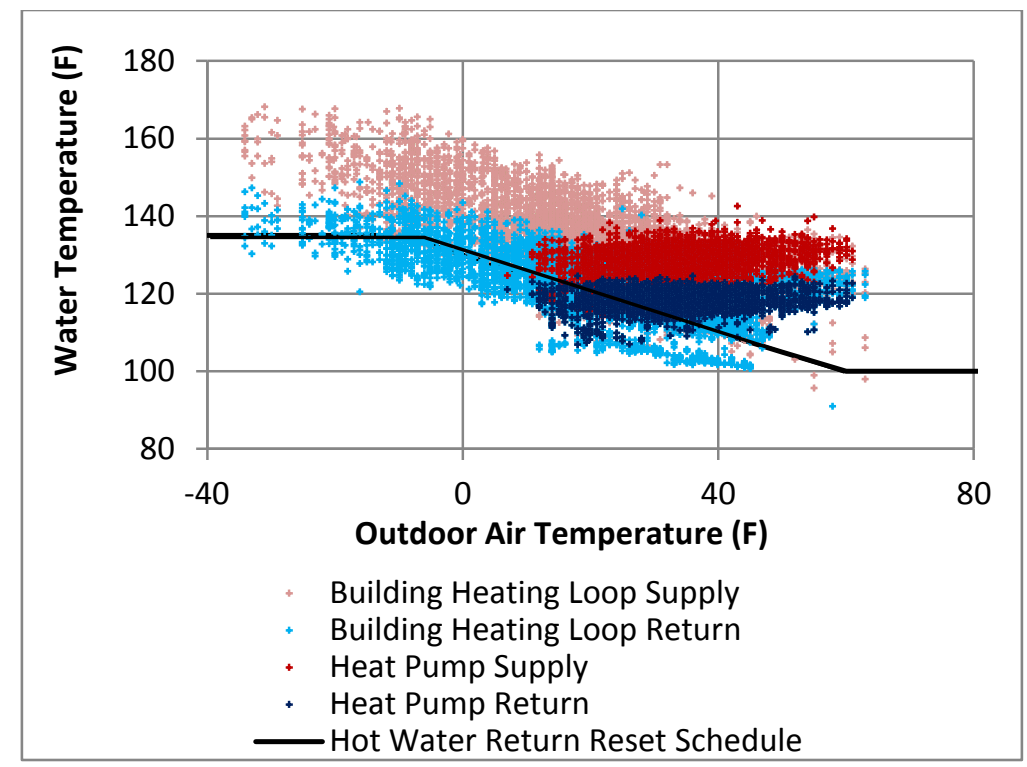

Fig. 36. Building heating loop and heat pump loop water temperature.

To achieve the maximum potential of GSHP system, the system must be able to operate as much as possible within the manufacturer-specified range of the leaving source-side temperatures $\left(30-55^{\circ} \mathrm{F}\right)$ and the leaving load-side temperatures $\left(110-135^{\circ} \mathrm{F}\right)$. From the catalog data, the heat pump heating capacity at $55^{\circ} \mathrm{F}$ leaving source-side water temperature ranges between $839.4 \mathrm{kBtu} / \mathrm{h}$ at $110^{\circ} \mathrm{F}$ leaving hot water temperature and $758.7 \mathrm{kBtu} / \mathrm{h}$ at $135^{\circ} \mathrm{F}$ leaving hot water temperature. Based on the assumption of $3 \mathrm{gpm} / \mathrm{ton}$, for a $150 \mathrm{gpm}$ constant supply water flow rate, the heat pump can provide a TD of $10.1^{\circ} \mathrm{F}$ at $135^{\circ} \mathrm{F}$ and $11.2^{\circ} \mathrm{F}$ at $110^{\circ} \mathrm{F}$ leaving hot water temperature. ${ }^{8}$ To provide this TD, the heat pump would operate when the building return water temperature is $125^{\circ} \mathrm{F}$ or below, or the $\mathrm{OA}$ temperature is $10^{\circ} \mathrm{F}$ or above. Below this temperature, the heat pump cannot operate due to the high return temperature from the building hot water loop (according to the OA reset schedule discussed previously). The heat pump supply water temperature (THPS) schedule thus derived is shown in Fig. 37, which is used as a basis for the subsequent analysis.

${ }^{8}$ If the supply water flow rate is reduced to $80.9 \mathrm{gpm}$ (as estimated according to the setting of the circuit setter at the load side loop, as mentioned in Section 2.3.2), the heat pump would provide a temperature differential of $18.7^{\circ} \mathrm{F}$ at $135^{\circ} \mathrm{F}$ leaving hot water temperature and $16.9^{\circ} \mathrm{F}$ at $110^{\circ} \mathrm{F}$ leaving hot water temperature. 


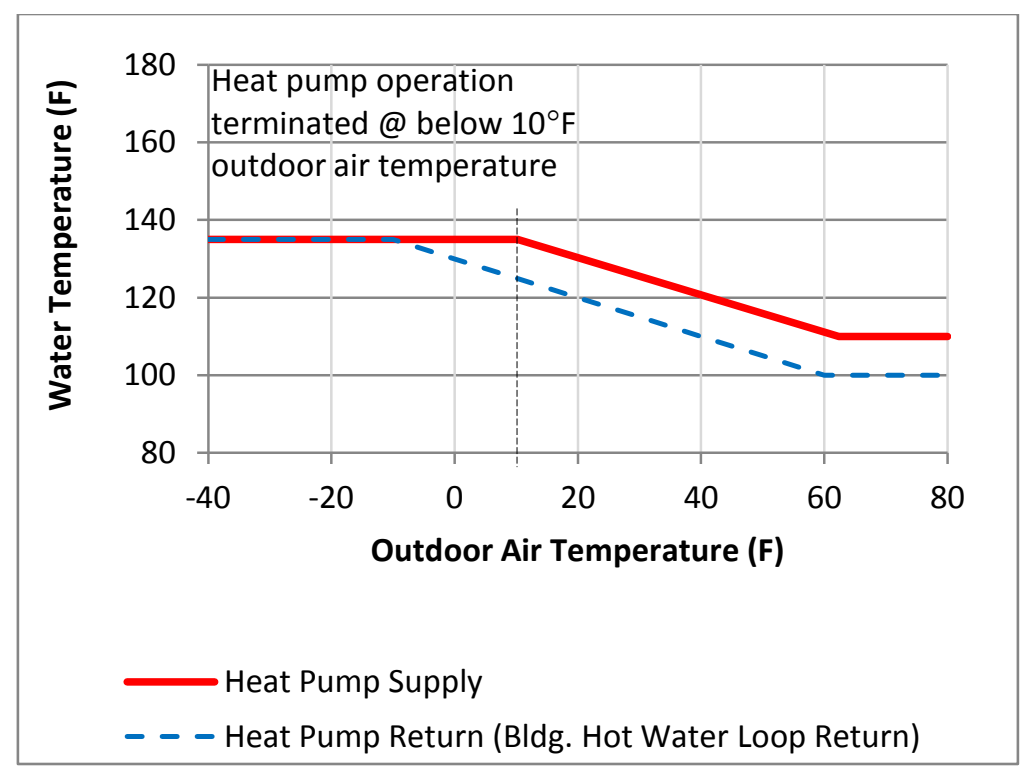

Fig. 37. Recommended schedule for heat pump loop water temperature.

\subsubsection{Heat Pump Capacity}

From the heat pump catalog data, the heating capacity can be determined as a function of leaving sourceside and leaving load-side water temperature. For the installed 50 ton heat pump, the heating capacity ranges between $526.6 \mathrm{Btu} / \mathrm{h}$ and $839.4 \mathrm{Btu} / \mathrm{h}$ at $30-55^{\circ} \mathrm{F}$ leaving source-side temperature and $120-135^{\circ} \mathrm{F}$ leaving load-side hot water temperature (with higher capacity at higher source-side and lower load-side water temperature). Measured data in Fig. 38 shows that the ground loop return water temperature (i.e., leaving source-side temperature) ranges between $60^{\circ} \mathrm{F}$ and $70^{\circ} \mathrm{F}$. This exceeds the $30-55^{\circ} \mathrm{F}$ range in the heat pump catalog. With a conservative assumption for the heat pump capacity corresponding to $55^{\circ} \mathrm{F}$ leaving source-side temperature, the heating capacity can be determined as a function of leaving load-side temperature using the curve-fit shown in Fig. 38.

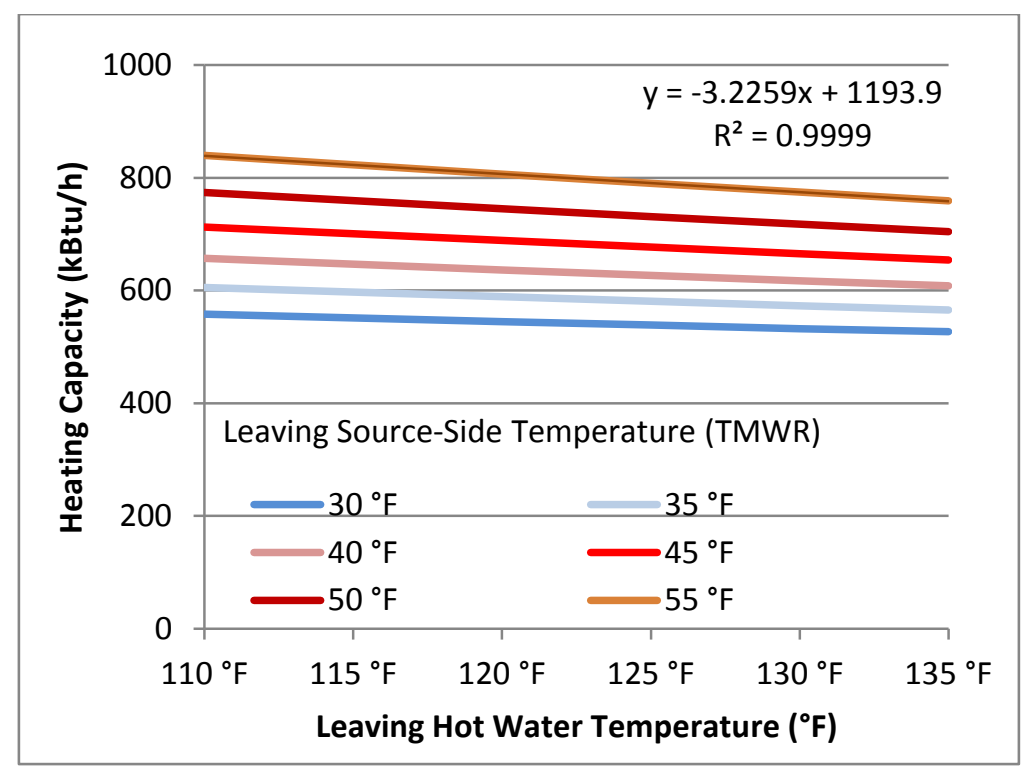

Fig. 38. Heat pump heating capacity as function of heat pump load-side supply water temperature. 


\subsubsection{Heat Delivered by Heat Pump}

If the heat pump is operated to provide heating to its maximum capacity as determined above, it would provide the entire building heating loads when the OA temperature is at $10^{\circ} \mathrm{F}$ or above. The steam system would be required only during hours when the OA temperature drops below $10^{\circ} \mathrm{F}$, as shown in Fig. 39(a). During November-January, at least $76 \%$ of the monthly heating loads would be met by the installed GSHP system [Fig. 39(b)]. When aggregated, the heat pump would deliver 2,882 MMBtu/year, which is $87.7 \%$ of the annual heating loads.

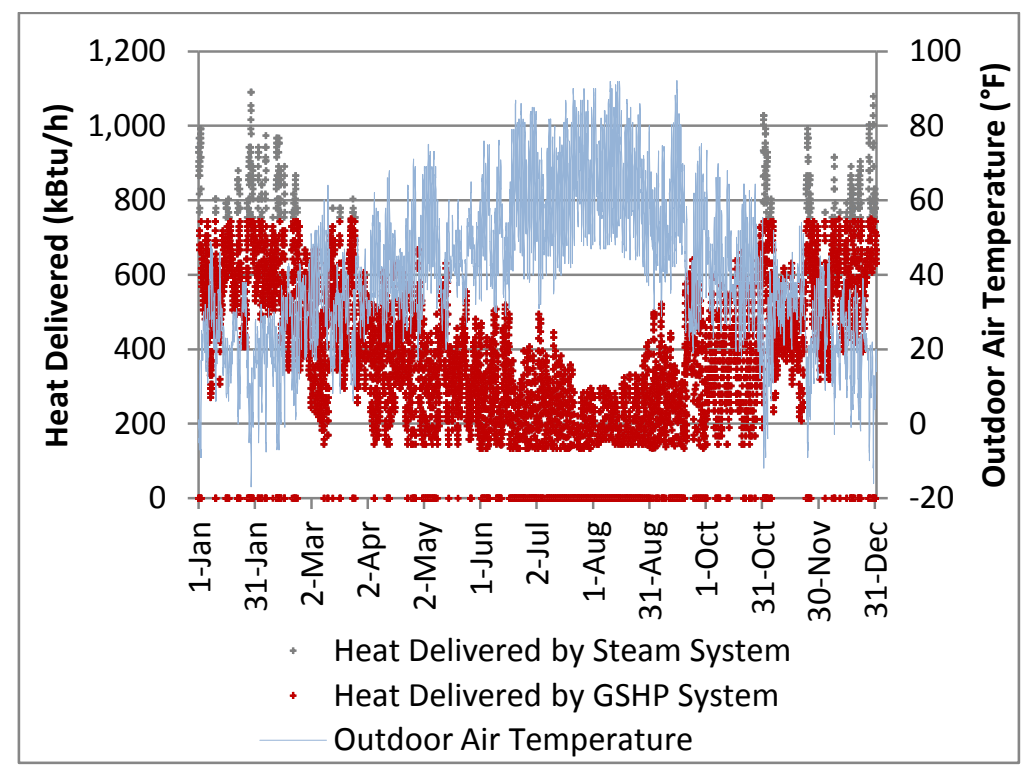

(a)

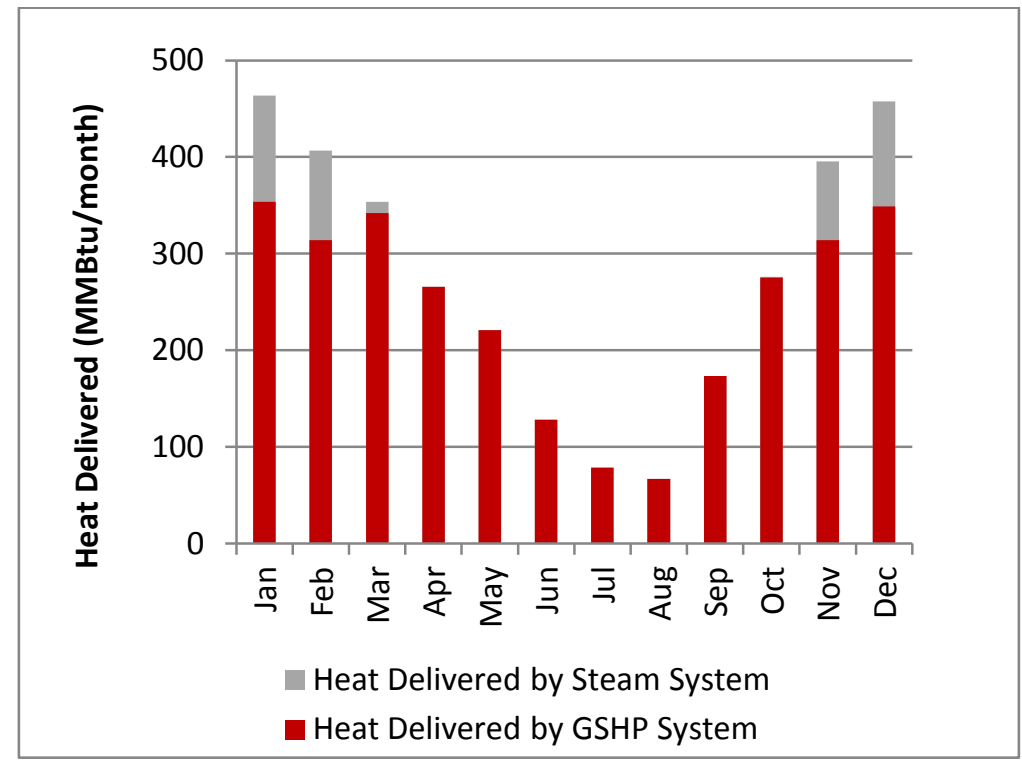

(b)

Fig. 39. Predicted heat delivered by heat pump and steam system. 


\subsubsection{Heating COP of Heat Pump}

The heating COP of the heat pump is determined from the curve-fit of the manufacturer's performance data provided for varying leaving source-side water and leaving load-side hot water temperature. For the installed 50 ton heat pump, the heating COP ranges between 2.5 and 5.2 at $30-55^{\circ} \mathrm{F}$ leaving source-side temperature and $120-135^{\circ} \mathrm{F}$ leaving load-side hot water temperature (with higher COP at higher sourceside and lower load-side water temperature). Measured data in Fig. 26 shows the leaving source-side water temperature range of $60-70^{\circ} \mathrm{F}$ and leaving hot water temperature range of $120-135^{\circ} \mathrm{F}$. No dependence on the OA temperature was observed in the measured data. However, to achieve the maximum potential of the GSHP system, load-side hot water supply temperature of the heat pump should be reset according to the schedule shown in Section 3.1.3. With a conservative assumption for the heat pump heating COP corresponding to $55^{\circ} \mathrm{F}$ leaving source-side temperature, and scheduled leaving sourceside temperatures, the heating COP of the heat pump ranged between 3.6 and 5.12, as shown in Fig. 40. The lower efficiency in the winter corresponds to the higher heat pump load-side supply temperature controlled by the OA reset schedule. The annual average heating COP of the heat pump is 4.19.

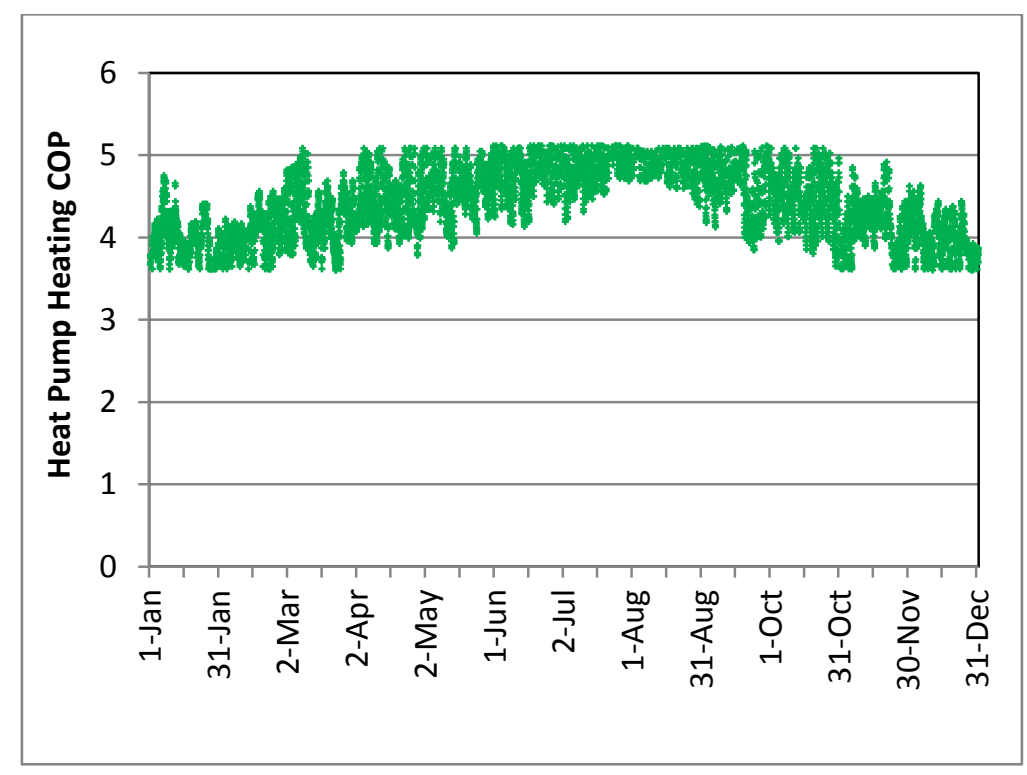

Fig. 40. Predicted heat pump heating COP.

\subsubsection{Energy Use of Heat Pump}

Heat pump energy consumption is calculated from the heating COP and heat output of the heat pump. As shown in Fig. 41(a), for a typical year, the heat pump hourly power consumption ranged between $7.7 \mathrm{kWh}$ and $61 \mathrm{kWh}$. The monthly heat pump energy use was up to 26,229 kWh in January [Fig. 41(b)]. When aggregated, the total heat pump energy use was $201,335 \mathrm{kWh} / \mathrm{year}$. 


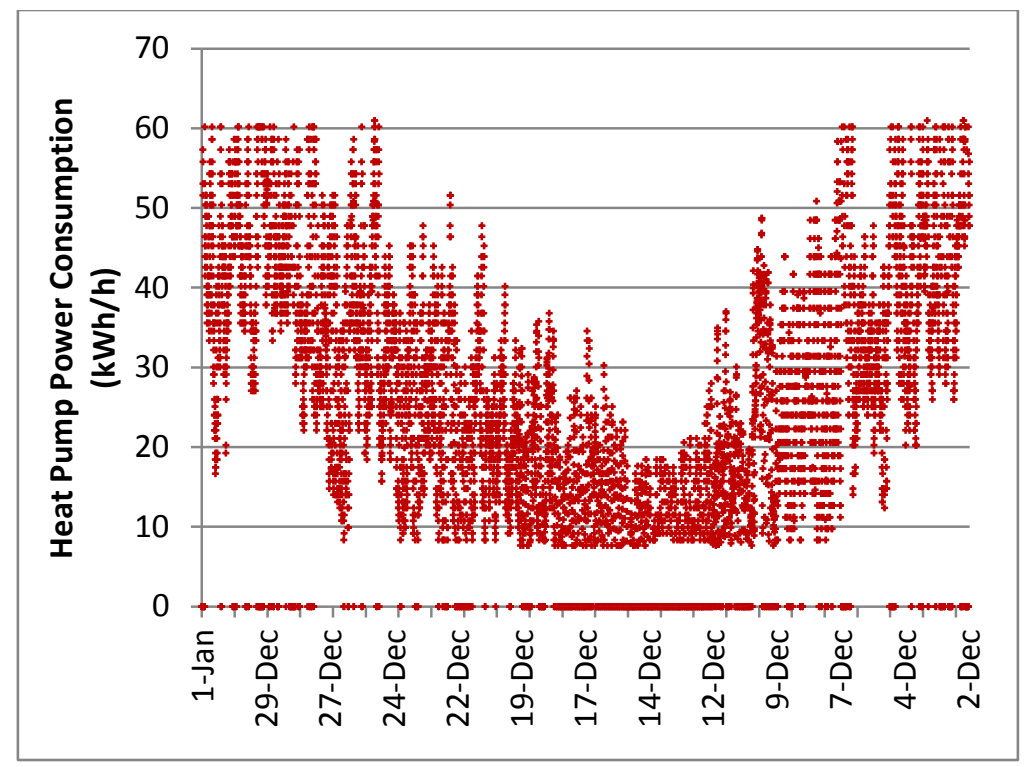

(a)

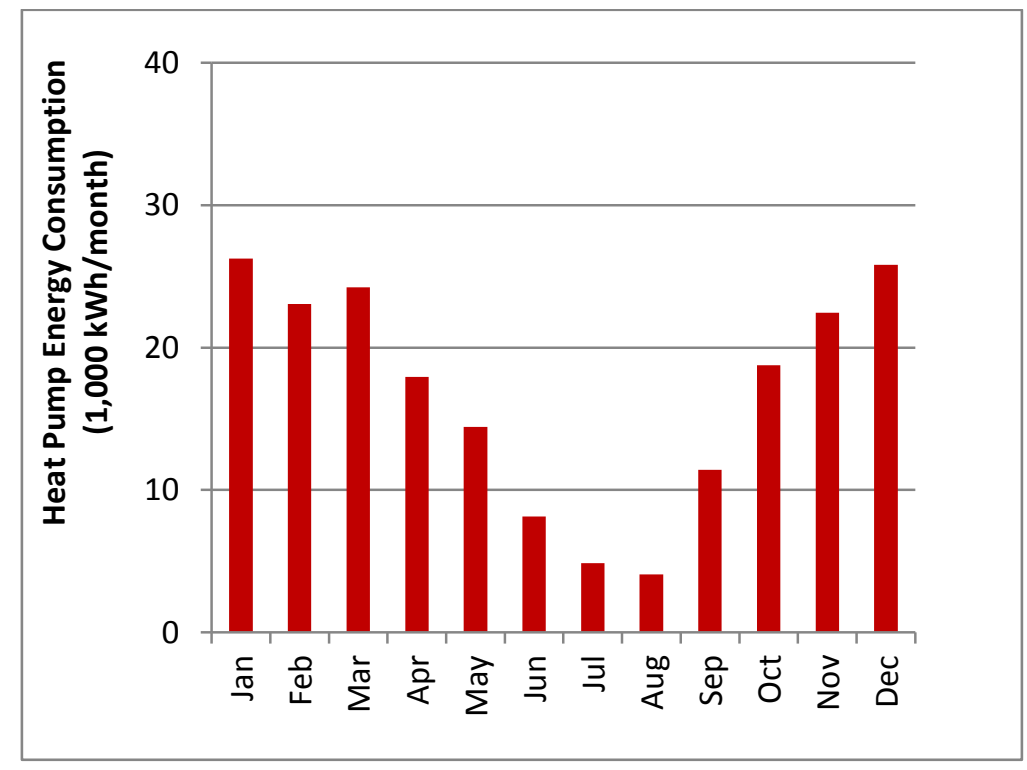

(b)

Fig. 41. Predicted heat pump energy use.

\subsubsection{Ground Loop Pump Power}

The water in the ground loop is circulated by two redundant $7.5 \mathrm{hp}$ constant speed TACO pumps. When in operation, the ground loop pumping power is $4.476 \mathrm{~kW}$ as discussed previously. It is assumed that the pump cycles on/off with the heat pump, which means that the pumping power ratio will be a constant. To estimate the pumping power ratio, a curve-fit for the daily ground loop pump energy use is derived as a function of the heat pump daily heat output based on the measured data, as shown in Fig. 42. From this curve-fit, the average hourly pumping energy use was determined. As shown in Fig. 43(a), the hourly pumping energy use ranged between $1.3 \mathrm{kWh}$ and $7.3 \mathrm{kWh}$. Figure 43(b) shows the monthly pumping 


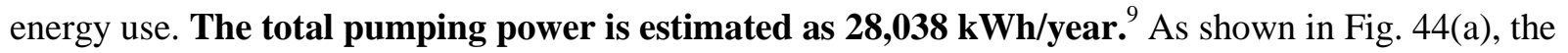
pumping power fraction (fraction of total GSHP energy use) ranges between 10.7\% and $14.5 \%$. As shown in Fig. 44(b), the average pumping power fraction ranged between $11.6 \%$ in the winter and $13.8 \%$ in the summer (when heating loads were relatively small), with an annual average of $12.2 \%$.

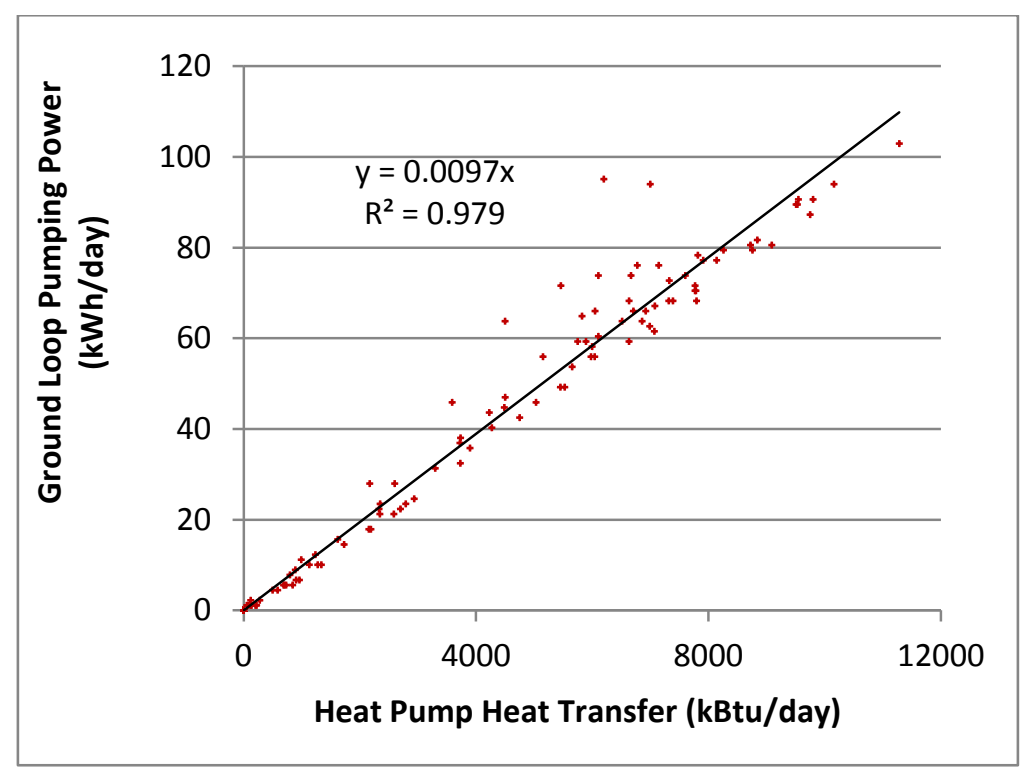

Fig. 42. Curve-fit of ground loop pumping energy use as a function of heat pump heat output.

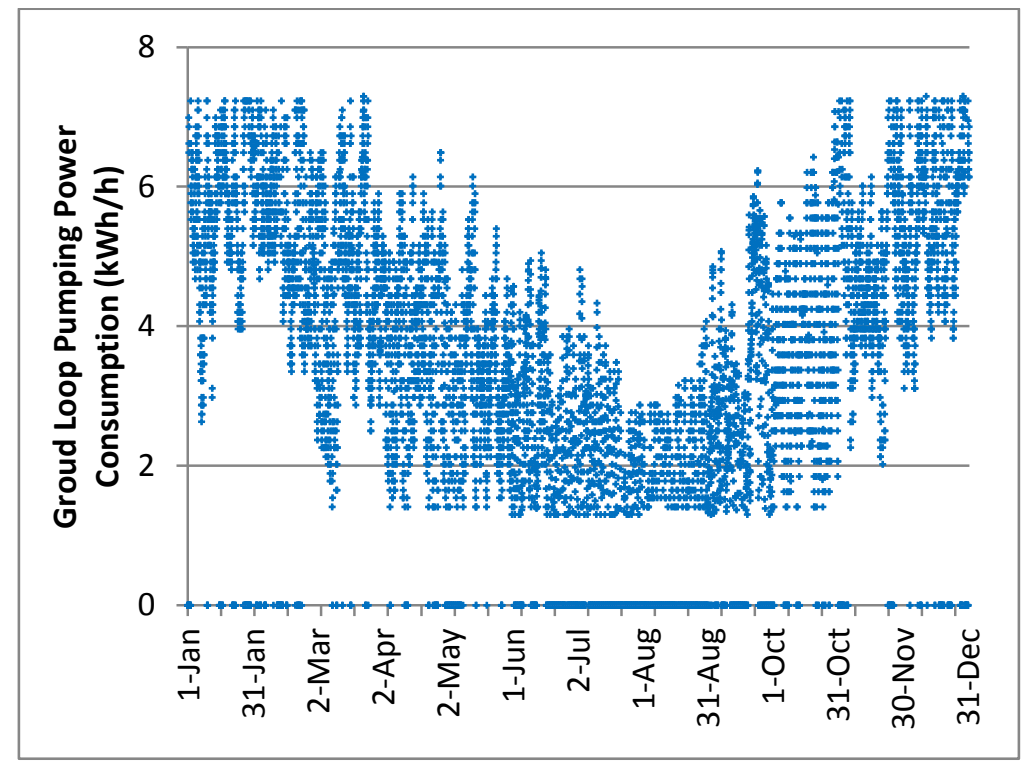

(a)

\footnotetext{
${ }^{9}$ Assuming continuous operation of the pump with $4.476 \mathrm{~kW}$ constant power draw, the pumping energy use is estimated as $30,303 \mathrm{kWh} / \mathrm{year}$. Thus, in lieu of measuring the pump power draw, the assumption of constant power draw could result in overestimating the pumping energy use by up to $7 \%$.
} 


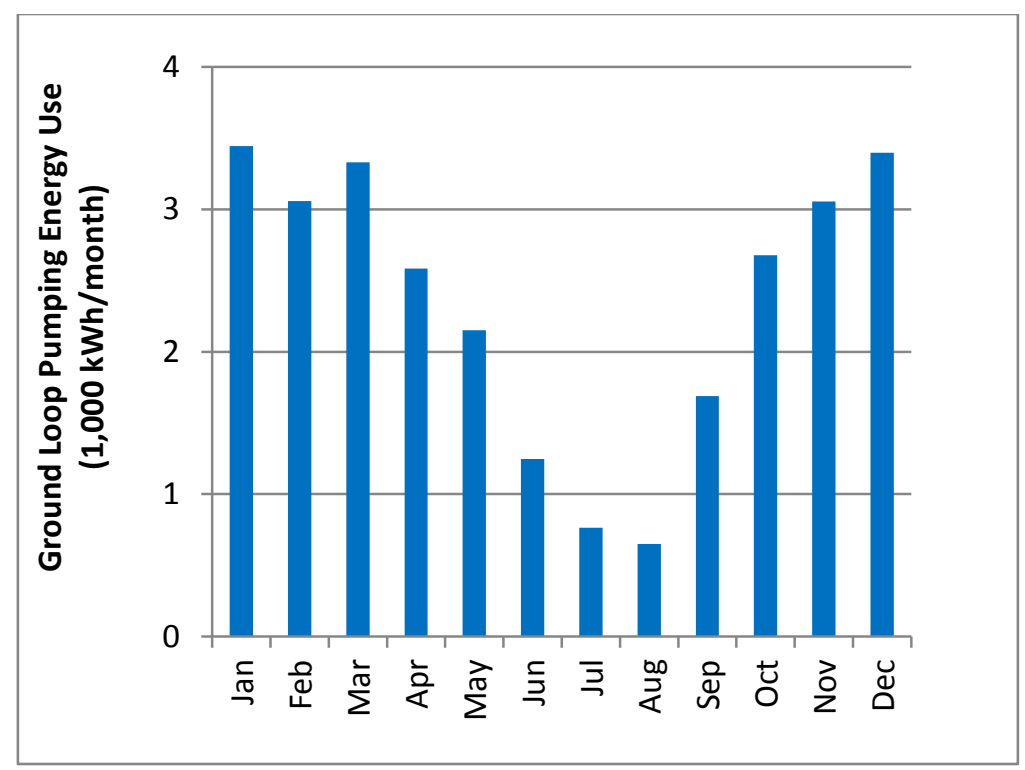

(b)

Fig. 43. Predicted monthly ground loop pump energy use.

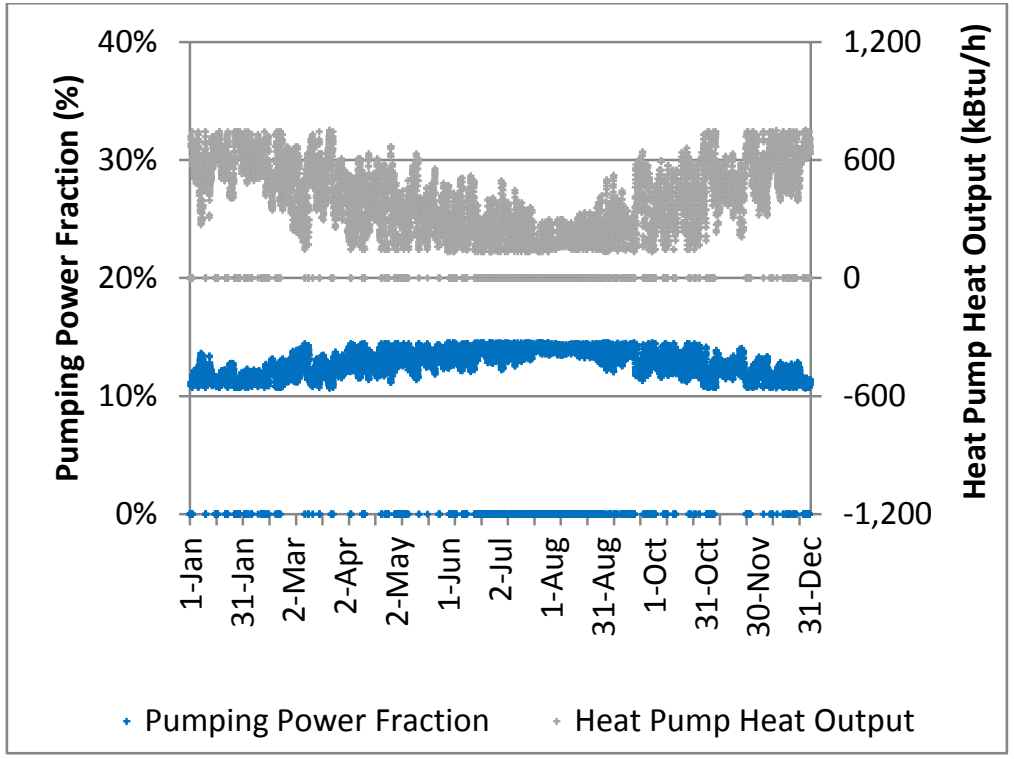

(a) 


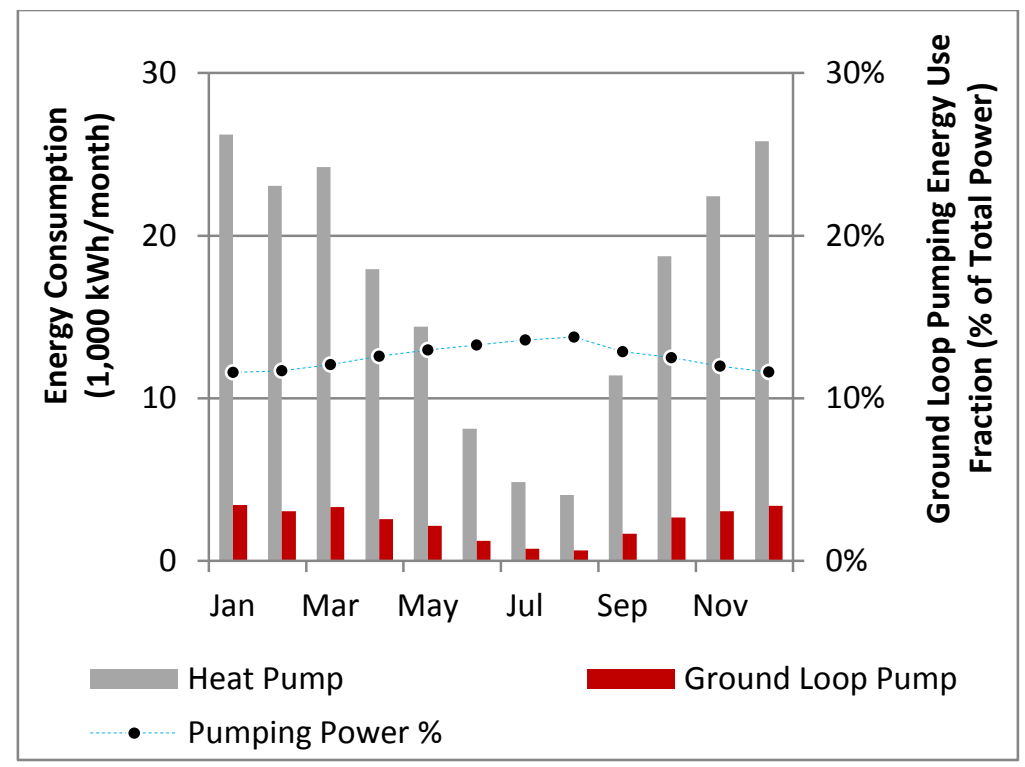

(b)

Fig. 44. Predicted ground loop pump energy use fraction.

\subsubsection{Heating COP of GSHP system}

The overall GSHP system heating COP is calculated by dividing the total heat pump heat output by total energy use, combining the heat pump energy use and ground loop pumping energy use. As shown in Fig. 45, for the assumptions given above, the heating COP of the GSHP system ranged between 3.22 and 4.37, with an annual average of 3.68 .

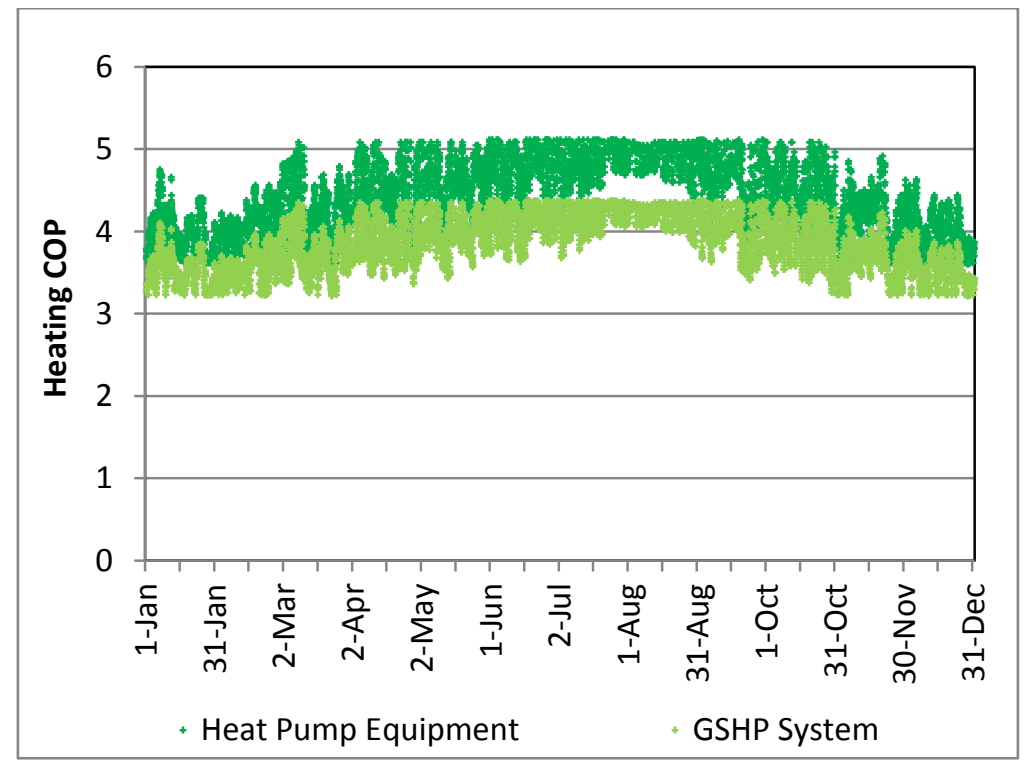

Fig. 45. Predicted heating COP of heat pump equipment and GSHP system. 


\subsubsection{Summary of Full-Year Performance of GSHP System}

The predicted annual energy analysis results are plotted in Fig. 46 along with the measured data during January-April 2014, when the GSHP system operated in the heating mode. A summary of the comparison is shown in Table 4.

Figure 46 shows the scatter plots of predicted and measured data-based estimates of the hourly heat pump energy use, ground loop pump power fraction, heat pump heating COP, and GSHP system COP against the heat delivered by the heat pump. Clearly, the predicted and the measured heat pump energy use match well because both use the same heat pump performance curves. The predicted ground loop pump power fraction is smaller than measurement-based fractions at lower heating loads, because the pump energy use is predicted by use of a constant pumping power ratio based on the assumption that the pump cycles on/off with the heat pump. In contrast, the measurement-based estimate used a constant power draw for the full time-step when the heat pump was operating. The predicted heating COP of the heat pump and GSHP system were higher than the measurement-based estimates, especially during milder weather with lower heating loads. The improved operational efficiency of the heat pump is a result of the recommended OA reset schedule for the heat pump load-side supply water temperature (shown in Fig. 37), which combined with the lower pumping power fraction resulted in the higher operating efficiency of the GSHP system.
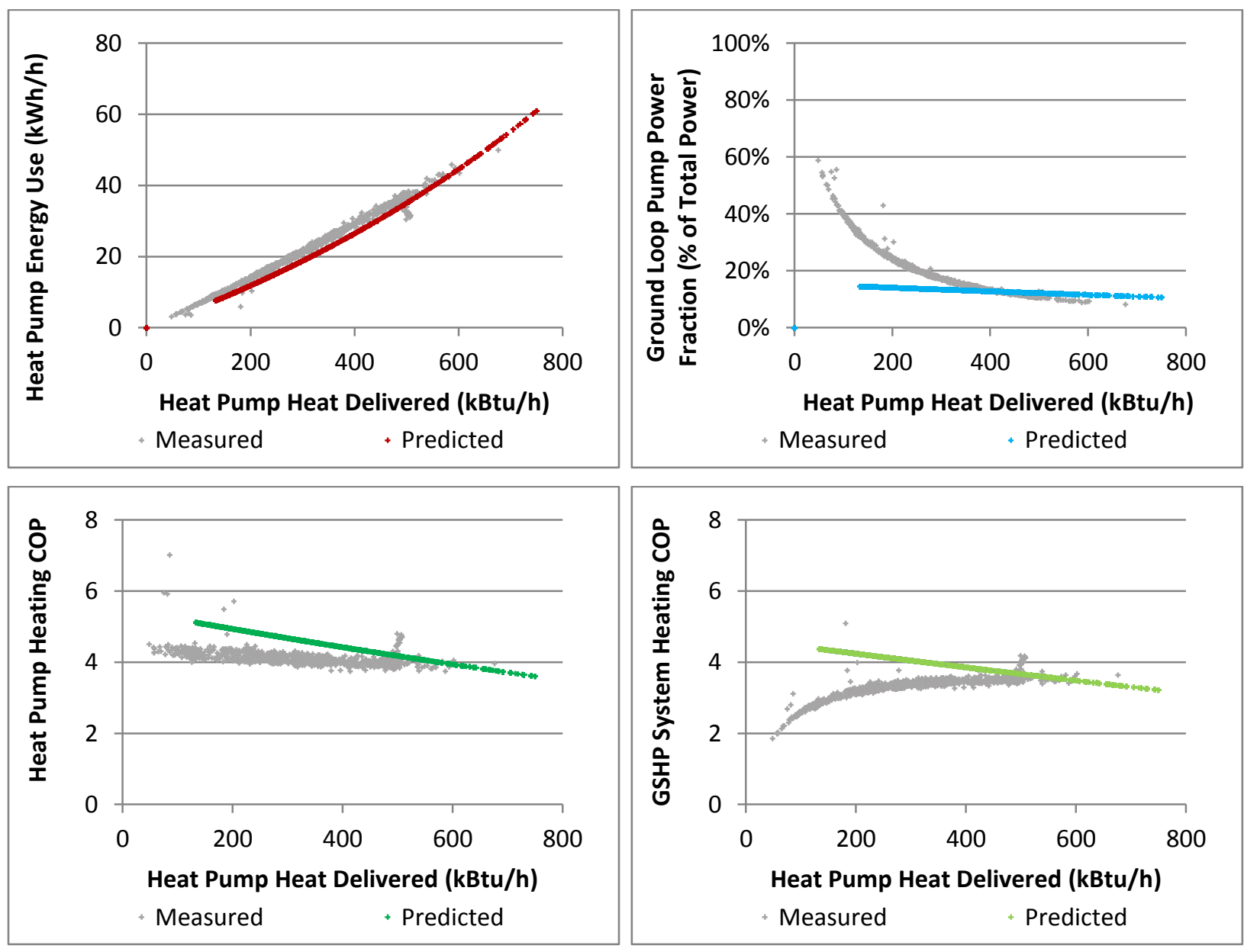

Fig. 46. Comparison of measured and predicted performance of GSHP system. 
Table 4 shows that the GSHP system can provide $87.7 \%$ of the entire annual building heating loads compared to $39.5 \%$ based on January-April measured data. The predicted heating COPs of the heat pump and the GSHP system for the full-year operation are 3.95 and 3.49, respectively, which are about 5-6\% higher than that calculated based on the measured data. As mentioned before, the improved performance and longer run-time are the results of the recommended OA reset schedule for the heat pump load-side supply water temperature (shown in Fig. 37). The pumping energy use is $12.2 \%$ of the total GSHP system energy use, which is $4.2 \%$ higher than that estimated based on the measured data.

Table 4. Summary of predicted full-year performance data

\begin{tabular}{|l|c|c|c|c|}
\hline & Unit & $\begin{array}{c}\text { January-April } \\
\text { Measured }\end{array}$ & $\begin{array}{c}\text { Full-Year } \\
\text { Predicted } \\
\text { (TMY3) }\end{array}$ & \% Difference \\
\hline Building heating loads & MMBtu & 1,126 & 3,286 & - \\
\hline Cumulative heat output & MMBtu & 445 & 2,882 & - \\
\hline Cumulative heat pump energy use & $\mathrm{kWh}$ & 33,025 & 201,335 & - \\
\hline Cumulative well pump energy use & $\mathrm{kWh}$ & 4,390 & 28,038 & - \\
\hline Cumulative GSHP system energy use & $\mathrm{kWh}$ & 37,415 & 229,374 & - \\
\hline \% of building heating loads met & $\%$ & $39.5 \%$ & $87.7 \%$ & - \\
\hline Average COP of heat pump & - & 3.95 & 4.19 & $6.2 \%$ \\
\hline Average COP of GSHP system & - & 3.49 & 3.68 & $5.6 \%$ \\
\hline Percentage of pumping energy use & $\%$ & $11.7 \%$ & $12.2 \%$ & $4.2 \%$ \\
\hline
\end{tabular}

\subsection{Comparison with the Baseline System}

A comparison of the GSHP system was performed with the existing steam system as the baseline to determine the energy savings and environmental benefits. The existing system uses a steam HX to provide hot water to the building, with the steam produced by a natural gas-fired boiler. The heat is delivered to the building through a hot water distribution system and terminal. For the baseline scenario, the existing system was assumed to provide the entire building's heating loads. For the GSHP system scenario, it was assumed that the GSHP system would provide heat to its full capacity and the unmet loads would be provided by the existing system. The ground water loop, with a pump and piping, acts as a heat source for the heat pump. All components of the existing system are assumed to be the same.

Figure 47 shows the procedure to determine the energy use and operating cost of the two systems. The energy use of the baseline system was determined assuming $78 \%$ boiler efficiency. The energy use of the GSHP system scenario was determined as the sum of GSHP system energy use (as calculated in the previous section) and boiler energy use, which provided the remainder of the heating loads. 


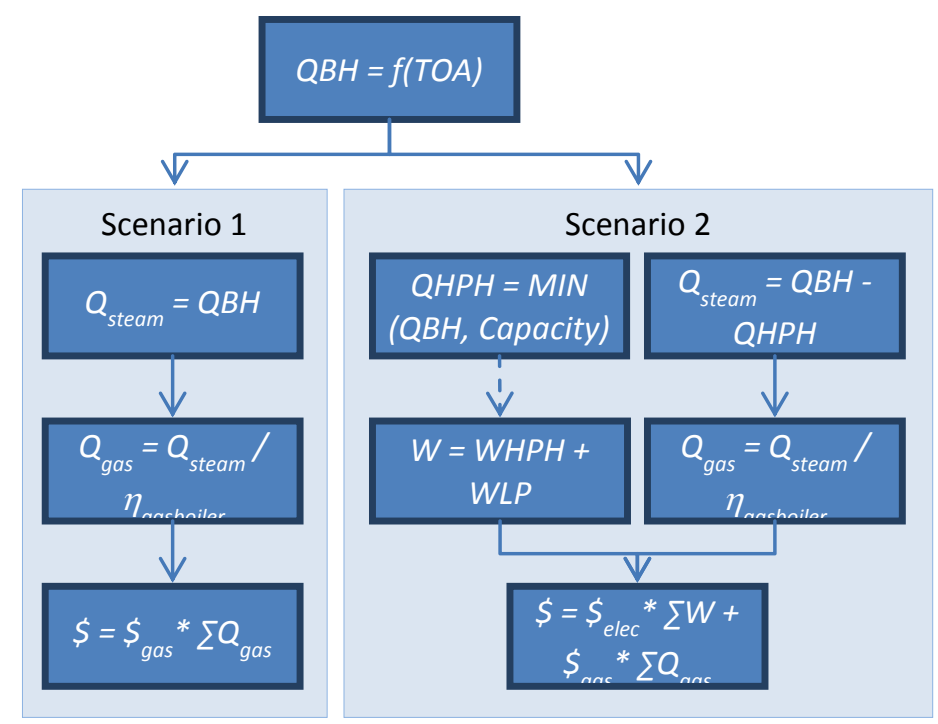

Fig. 47. Schematic of annual energy analysis.

Figure 48 shows the system efficiency of the GSHP system and baseline heating systems at varying building heating loads. While the efficiency of the baseline system (i.e., natural gas boiler) is assumed constant at 78\%, the GSHP system heating COP varies by the heating loads. The GSHP system is operated in the heating mode when the outdoor air temperature is below $60^{\circ} \mathrm{F},{ }^{10}$ which is when the building heating loads are $134 \mathrm{kBtu} / \mathrm{h}$. The TMY3 weather data of the site indicates that the lowest OA temperature is $-17^{\circ} \mathrm{F}$. At this temperature, the heating load peaks at $1,090 \mathrm{kBtu} / \mathrm{h}$. However, as discussed earlier, when OA temperature drops below $10^{\circ} \mathrm{F}$, the GSHP system cannot operate. For the operating conditions at the site, the GSHP provides heating up to a maximum capacity of $768 \mathrm{Btu} / \mathrm{h}$. So, within the $134 \mathrm{kBtu} / \mathrm{h}$ and $768 \mathrm{kBtu} / \mathrm{h}$ range the GSHP system heating COP varies between 3.2 and 4.4. As seen in the figure, the heating COP of the heat pump and GSHP system vary linearly with the heating loads, with higher COP at lower heating loads. However, the heating COP of the GSHP system efficiency does not increase at the same rate due to the ground loop pump operation.

\footnotetext{
${ }^{10}$ For this analysis, the heating loads for reheat during the cooling season (i.e., when the OA temperature is above $60^{\circ} \mathrm{F}$ ) are ignored because the measured data for determining the building cooling loads (and the reheat load) is unavailable.
} 


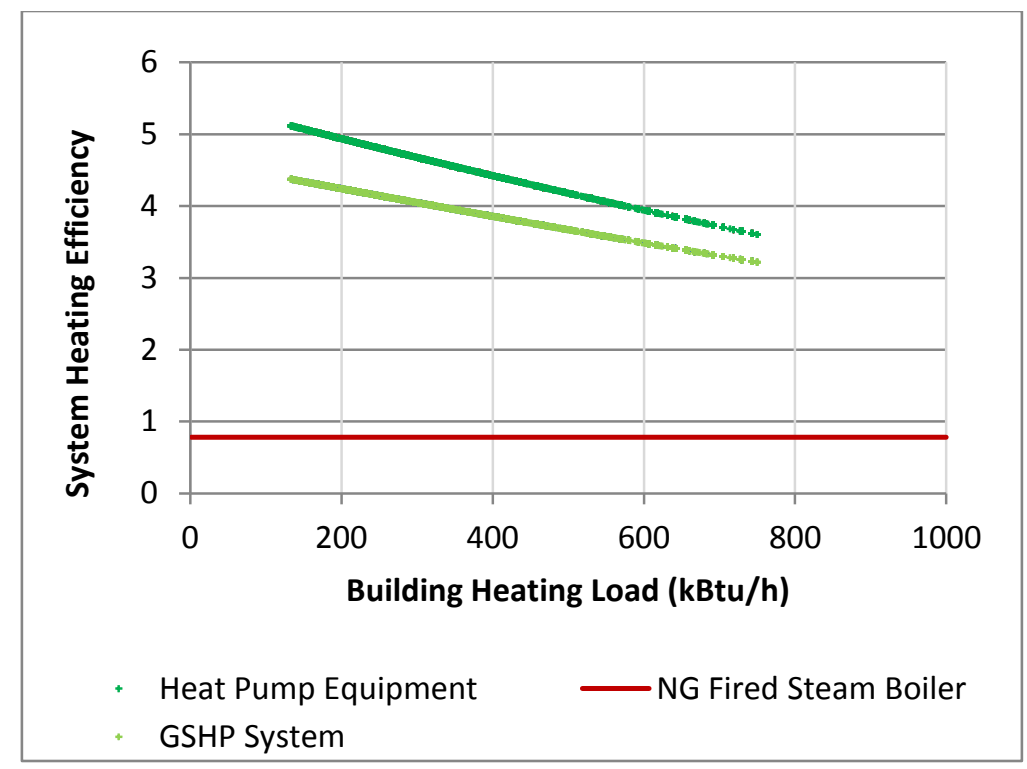

Fig. 48. System efficiency of the baseline system and GSHP system.

The bar charts in Fig. 49 compare the site and source energy consumption, energy cost, and $\mathrm{CO}_{2}$ emissions for the two systems. The source energy consumption for the two systems is calculated by using the source energy converting factors for natural gas and electricity in the region where the demonstration project is located. According to a report from National Renewable Energy Laboratory (NREL) (Deru and Torcellini 2007), the source-to-site energy converting factor for electricity in the western region of the United States is 2.894 per unit of delivered electricity, while the same factor for natural gas is 1.092 per unit of delivered natural gas.

The energy cost for the two systems is calculated on the basis of a \$9.63/MMBtu natural gas cost and a $\$ 0.08 / \mathrm{kWh}$ electricity cost, obtained from the site. Of note is that the operating cost savings compared with the natural gas boiler system depend greatly on the natural gas price.

The equivalent $\mathrm{CO}_{2}$ emissions $\left(\mathrm{CO}_{2} \mathrm{e}\right)$ of the two systems are calculated by using the emission factors for electricity and natural gas. According to the same NREL report, the $\mathrm{CO}_{2} \mathrm{e}$ emission factor for electricity in the western United States is $1.31 \mathrm{lb} / \mathrm{kWh}$ of delivered electricity. The $\mathrm{CO}_{2} \mathrm{e}$ emission factor for natural gas includes two parts: (1) the precombustion emission factor, which is $27.17 \mathrm{lb} / \mathrm{MBtu}$ of natural gas, and (2) the on-site combustion emission factor for natural gas boiler, which is $120.23 \mathrm{lb} / \mathrm{MBtu}$ of delivered natural gas.

The GSHP system annually saves 2,912 MMBtu of site energy and 1,769 MMBtu of source energy, and reduces 244,077 $\mathrm{lb}$ of $\mathrm{CO}_{2}$ emissions compared with the baseline system. In other words, the GSHP system annually resulted in $\mathbf{6 9 . 1 \%}$ site energy savings and $38.4 \%$ source energy savings, and $39.3 \%$ reduction in $\mathrm{CO}_{2}$ emissions compared with the natural gas-fired steam boiler system. The resulting operating cost savings were $\$ 17,227$ per year (42.5\% of the baseline). 

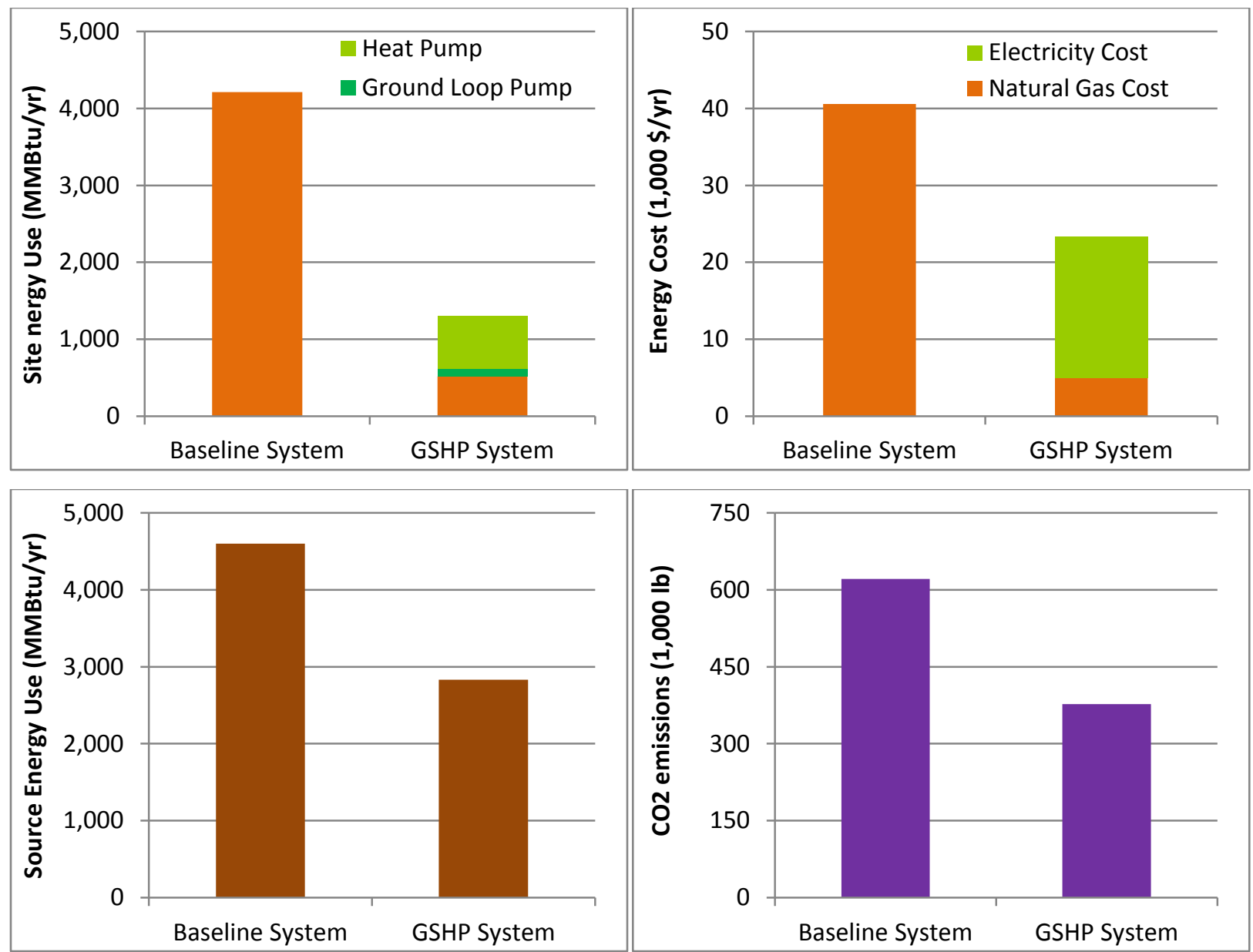

Fig. 49. Comparison of site and source energy use and $\mathrm{CO}_{2}$ emissions between the GSHP system and the baseline system. 


\section{CONCLUSION}

This case study analyzes the energy performance of a GSHP system installed in Natural Resources Building, a newly constructed research facility at Montana Tech. The GSHP system works in conjunction with the originally installed steam HX and an air-cooled chilled water system, and uses water in the nearby flooded mines as a heat source or heat sink. The actual performance of the system is analyzed with measured data for January through July 2014. The annual energy performance is predicted and compared with a baseline scenario, with the heating and cooling provided by the originally designed systems. The comparison is made in terms of energy savings, operating cost savings, cost-effectiveness, and environmental benefits. The following sections summarize the results of the analysis, the lessons learned, and recommendations for improvement in the control and operation of such systems.

\subsection{Energy Performance and Cost Effectiveness}

The measured performance data during January through July 2014 indicated that the GSHP system was operated intermittently from January through March, and shut off in May and June. Based on the aggregated measure data from January through April, the heating COP of the heat pump and the GSHP system were 4.0 and 3.5, respectively. Further analysis of the predicted full-year performance shows that the annual average COPs of the heat pump and GSHP system were 4.2 and 3.7, respectively, both of which were higher than those measured during the 4 month period. These figures represent a 5\% increase in the COP of the heat pump and a $6 \%$ increase in the COP of the GSHP system. These increases are due to the additional OA reset control for the heat pump.

The pumping power annually accounts for $12 \%$ of the total GSHP system energy use. A trend analysis of the measured data (Fig. 43) reveals that excessive pumping occurred at times when heating demands were low due to continuous operation of the constant speed pump in the ground loop.

Compared with the baseline system (i.e., the existing steam system using a natural gas boiler), the GSHP system achieved significant energy savings and $\mathrm{CO}_{2}$ emission reduction. The GSHP system demonstrated $77.7 \%$ site energy savings, $43 \%$ source energy savings, and $44 \% \mathrm{CO}_{2}$ emission reduction compared with the natural gas-fired boiler. The operating cost savings compared with the natural gas boiler system depend greatly on the natural gas price. For this analysis, a \$9.63/MMBtu natural gas cost and a $\$ 0.08 / \mathrm{kWh}$ electricity cost were used (these were obtained from the site). The operating cost savings were $\$ 17,227$ per year with these utility cost assumptions.

The installed cost ( $\$ 750,000$ for the mine loop HX, i.e., $\$ 15,000 /$ ton $)$ of the demonstrated GSHP system, which uses mine water as a heat source and heat sink, is higher than that of conventional GSHP systems (about $\$ 7,000 /$ ton on average in 2006 dollars, or $\$ 8,200 /$ ton in 2014 dollars $^{11}$ ) that use vertical bore ground heat exchangers. As an experimental work to research the potential of using mine water as a potential heat source/sink, the project cost may have included several other research-related costs, which will not exist for non-research projects. Unfortunately, the cost breakdown was not available to the authors when this study was conducted. Assuming $\$ 50,000$ cost of the 50-ton WWHP unit, the payback period is 46 years.

\footnotetext{
${ }^{11}$ Source: http://www.bls.gov/data/inflation_calculator.htm
} 
Table 5 provides a summary of comparison between the two systems. 
Table 5. Summary of comparisons between the GSHP system and the baseline system

\begin{tabular}{|l|c|c|c|}
\hline & $\begin{array}{c}\text { Steam HX served by a } \\
\text { natural gas boiler }\end{array}$ & GSHP system & Savings \\
\hline Site energy use (MMBtu) & 4,213 & 1,302 & $69.1 \%$ \\
\hline Source energy use (MMBtu) & 4,601 & 2,832 & $38.4 \%$ \\
\hline $\mathrm{CO}_{2}$ emissions (lb) & 621,046 & 376,969 & $39.3 \%$ \\
\hline Total annual energy cost (\$) & $\$ 40,574$ & $\$ 23,347$ & $42.5 \%$ \\
\hline Operating cost savings (\$) & - & - & $\$ 17,227$ \\
\hline Cost premium (\$) & - & - & $\$ 800,000$ \\
\hline Payback period (years) & - & - & 46 \\
\hline
\end{tabular}

${ }^{\mathrm{a}}$ Based on the utility rates for the site, which are $\$ 9.63 / \mathrm{MMBtu}$ and $\$ 0.08 / \mathrm{kWh}$.

\subsection{Issues and Limitations}

- Flow rate in the heat pump load-side loop was not measured and assumed constant. The heating delivered by the heat pump could be calculated using either 1) the constant flow rate assumption with measured water temperatures (Fig. 22) or 2) the manufacturer's performance data with measured water temperatures (Fig. 29). However, both estimates did not align, which indicates that the assumption of constant flow rate was not valid.

- It was desirable that the measurements include a full heating season, a full cooling season, and swing months with the heat pump operating. During the measurement period, the heat pump was not operated during May and June, and the building chilled water loop measurements were not available for July. As a result, the GSHP system's annual cooling performance could not be analyzed, which was important for the following reasons:

$\circ$ The mine water was found warmer than the outdoor air temperature in the winter and summer. This suggested that using the GSHP system to provide cooling would be less efficient than using the existing air-cooled chiller. However, this could not be verified.

- Operating the GSHP system only in the heating mode may potentially decrease the mine water temperature in the long-run and reduce the heating efficiency of the GSHP system. But, the tradeoff of operating the GSHP system for cooling in the summer at lower efficiency versus operating the GSHP system only for heating could not be analyzed.

$\circ$ During the summer, significant heating were observed due to the reheat loads. When the heat pump was providing cooling during daytime in the summer, the steam HX had to provide reheat to certain zones. If the cooling is provided only by the existing air-cooled chiller, the GSHP system may have to operate to also provide reheat loads, if any. However, the summertime operation of the systems could not be analyzed.

- Limited information was available about the baseline system (i.e., steam HX served by a natural gas boiler). Therefore, for the comparison of GSHP system annual performance, only general assumptions about the natural gas boiler efficiency were made.

- The project is an experimental work to research the potential for using mine water as a potential heat source and heat sink. The project cost may have included other costs not related to the installation of the GSHP system. Since the cost breakdown was not available, a fair evaluation of the cost effectiveness of the GSHP system could not be performed.

\subsection{Lessons Learned and Recommendations for Further Improvements}

- To achieve its maximum potential, the GSHP system must be able to operate as much as possible within the manufacturer-specified range of operating conditions. Also, its operating efficiency can be maximized by optimizing the leaving source-side and load-side water temperatures. The following measures can be utilized to achieve these objectives: 
- By optimizing the OA reset schedule for the building hot water loop to allow lower supply and return water temperature and lower flow rate, the operation of GSHP system can be maximized even at peak heating load conditions, while meeting the manufacturespecified operating conditions.

- A holistic system design approach is needed to select and size the heat delivery equipment/ terminal units that do not require very high supply hot water temperature to deliver sufficient heat to the building. A lower supply temperature would result in higher operating efficiency and maximum operation of the heat pump.

- Building chilled water loop measurements for estimating the building cooling loads and a longterm measurements of the mine water temperature (which stays warmer than the outdoor air) are needed to evaluate the tradeoff between using the mine water a) solely as a heat source, which may result in temperature rise over the years, thereby, reducing the heating efficiency of the GSHP system, and (b) both as a heat source and a heat sink, which would result in relatively stable mine water temperature and stable GSHP heating and cooling efficiency over the years, but provide cooling at a lower efficiency compared to the existing air-cooled chiller.

- Control of heat pump operation should be improved to avoid a large amount of summertime reheat by the steam heating system, caused by the heat pump operating in the cooling mode.

- Pumping control could be refined to avoid wasting pumping energy when the heat pump is not in operation. 


\section{REFERENCES}

Multistack. 2014. Multistack Water-to-Water Heat Pump Product Catalog Data for R-410A or R-134a Refrigerant. Available at:

http://www.multistack.com/Portals/0/Literature/Catalogs/Water\%20To\%20Water\%20Heat\%20Pump\%20 Catalog.pdf

Deru, M., and P. Torcellini. 2007. Source Energy and Emission Factors for Energy Use in Buildings. NREL/TP-550-38617. National Renewable Energy Laboratory, Golden, Colo. 